Design of a Pilot Silvicultural Biomass

Farm at the Savannah River Plant

March 1979

Prepared for

U.S. Department of Energy

Assistant Secretary for Energy Technology

Division of Solar Energy Fuels from Biomass

Under Contract No. EG-77-C-01-4101 


\section{DISCLAIMER}

This report was prepared as an account of work sponsored by an agency of the United States Government. Neither the United States Government nor any agency Thereof, nor any of their employees, makes any warranty, express or implied, or assumes any legal liability or responsibility for the accuracy, completeness, or usefulness of any information, apparatus, product, or process disclosed, or represents that its use would not infringe privately owned rights. Reference herein to any specific commercial product, process, or service by trade name, trademark, manufacturer, or otherwise does not necessarily constitute or imply its endorsement, recommendation, or favoring by the United States Government or any agency thereof. The views and opinions of authors expressed herein do not necessarily state or reflect those of the United States Government or any agency thereof. 


\section{DISCLAIMER}

Portions of this document may be illegible in electronic image products. Images are produced from the best available original document. 
Available from:

National Technical Information Service (NTIS)

U.S. Department of Commerce

5285 Port Royal Road

Springfie1d, Virginia 22161

Price: Printed Copy:

$\$ 7.25$

Microfiche:

$\$ 3.00$ 
HCP/T4101-01

Dist. Category UC-61

\section{Design of a Pilot Silvicultural Biomass Farm at the Savannah River Plant}

March 1979

Prepared By:

D.J. Salo

J.F. Henry

R.E. Inman

The MITRE Corp.

McLean, Va.

Prepared for

U.S. Department of Energy

Assistant Secretary for Energy Technology

Division of Solar Energy Fuels from Biomass

Under Contract No. EG-77-C-01-4101
This retrot NOT

This report was prepared as an accoutit of 'work sponsored by the United States Government. Neither the United States nor the United States Department of Energy, nor any of their employees, nor any of their contractors, subcontractors, of their employees, makes any warranty, express or implied, or assumes any'legal liability or responsibility for the acrurncy, comploteness or usefulness of any information, apparatus, product or process disclosed, or represents that its use would 'not infringe privately owned rights. 


\section{NOTICE}

This report was prepared as an account of work sponsored by the United States Government. Neither the United States nor the United States Department of Energy, bor any of their employees, makes any warranty, express or implied, or assumes any legal liability or. responsibility for the accuracy, completeness, or usefulness of any information, apparatus, producz or process disclosed, or represents that its use would not intringe privately owned rights. Reference herein to any specific commercial product, process, or service by trade name, mark, manufacturer. or otherwise, does not necessarily constitu te or imply its endorsement, recommendation, or favoring by the United States Government or any agency thereof. The views and opinions of authors expressed herein do not necessarily state or reflect those of the United States Government or any agency thereof. 
Metrek has designed a detailed plan for the establishment and operation of a 1000-acre silvicultural biomass farm at the Savannah River Plant, Aiken, South Carolina. The plan includes a discussion of possible sites, layout and design, and installation and operation. The estimated costs of installation and operation are also presented. 
THIS PAGE

WAS INTENTIONALLY

LEFT BLANK 
TABLE OF CONTENTS

$\underline{\text { PAGE }}$

LIST OF ILLUSTRATIONS vii

LIST OF TABLES ix

SUMMARY $\quad x i$

INTRODUCTION

SELECTION OF THE SAVANNAH RIVER PLANT 3

Suitability Criteria 3

Site Recommendation $\quad$ · 4

IDENTIFICATION OF SITES AT THE SAVANNAH RIVER PLANT

Suitability líiteria 7

Selection of Alternative Sites $\quad 11$

Site Area Recommendation $\quad 15$

DESIGN AND PLANNING OF THE PILOT SILVICULTURAL BIOMASS FARM 17

Pilot Silvicultural Biomass Farm Design Plan 17

$\begin{array}{ll}\text { Overall Planning Schedule } & 27\end{array}$

Biomass Farm Operation $\quad 43$

IMPLEMENTATION PLAN FOR THE PILOT SILVICULTURAL BIOMASS FARM 63

Installation Plan for the Pilot Silvicultural Biomass Farm

Installation of Modules II, IV and VI

Installation of Modules III and V 74

Summary of Planting Schedule $\quad 74$

Operation Plan for the Pilot Silvicultural Biomass Farm 76

COST ESTTMATES FOR INSTALLATION AND OPERATION 79

Operation Cost Estimates $\quad 82$

Summary Yearly Budgets. $\quad 89$

Cost of Biomass and Energy Efficiency 89

APPENDIX: TECHNICAL AND COST DATA BASE USED FOR THE DESIGN OF THE PILOT SILVICULTURAL BIOMASS FARM 
THIS PAGE

WAS INTENTIONALLY

LEFT BLANK 


\section{LIST OF ILLUSTRATIONS}

Figure Number

$\underline{\text { Page }}$

1

2

3

4

5

6

7

8

9

10

11

12

13

14

15

16
Location of the Savannah River Plant

Location of Timber Compartments Containing Alternative Sites for a Pilot Silvicultural

Blomass Farm at the Savannah River Plant

Location of the Jackson Site - Pilot

Silvicultural Biomass Farm

Location of the Route 278 Site - Pilot

Silvicultural Biomass Farm

Layout of Jackson Site

Layout of Route 278 Site

Proposed Schedule of Operations for the Pilot Silvicultural Biomass Farm

Irrigation Layout - Jackson Site

Irrigation Layout - Route 278 Site

Overall Schedule of Field Operations for the Pilot Silvicultural Biomass Farm

Schedule of Installation of Module I (Option 1: Salvage Sale)

Schedule of Installation-of Module I (Option 2: Land Clearing with No Wưd Recovery)

Schedule of Installation of Modules II, IV, and VI

Schedule of Installation of Modules III and V

Summary Schedule for the Installation of the Pilot Silvicultural Biomass Farm

Schedule of Yearly Operations in the Various Modules of the Pilot Silvicultural Biomass Farm
24

37 


\section{THIS PAGE}

\section{WAS INTENTIONALLY LEFT BLANK}




\section{LIST OF TABLES}

Table Number

Page

I Characteristics of Potential SRP-Pilot

Silvicultural Biomass Farm Sites

II Site Characteristics of the Pilot

Silvicultural Biomass Farm. Sij.vicultural Biomass Farm

Data Base for Site Preparation and Improvement at the Pilot Silvisultural Biomass Farm

Characteristics of the Irrigation System

Data Base for Planting

Equipment and Services for the Research and Storage Areas Lifetime of the Pilot Silvicultural Biomass Farm (Base Case) 


\section{LIST OF TABLES (Concluded)}

Table Number

Page

XVI

Operations for Schedule of Installation of

First Modules (Option 1 - Salvage Sale Approach)

XVII

Operations for Schedule of Installation of First

69

Modules (Option 2 - Land Clearing Without Wood

Recovery)

XVIII

Operations for Schedule of Installation of Modules Two, Four and Six (Planting in 1982, 1984 , and 1986

XIX

Operations for the Schedule of Installation of Modules Three and Five (Planting in 1983 and 1985)

$\mathrm{XX}$

Installation Costs - Jackson Site

XXI

Instàllation Costs - Route 278 Site

XXII

Summary of Installation Costs for the Pilot Silvicultural Biomass Farm (Jackson and Route 278 Sites)

XXIII

Yearly Operating Costs for the Pilot

Silvicultural Biomass Farm (Jackson and

Route 278 Sitco)

XXIV

Summary of thic Projected Operating Costs for

88

$\mathrm{XXV}$ the Pilot Silvicultural Biomass Farms

Summary Yearly Total Budget for the Lifetime 
In support of the Fuels From Biomass Systems Branch (FFB) of the Department of Energy (DOE), MITRE has developed a plan for the establishment of a Pilot Silvicultural Biomass Farm (PSBF) at the Savannah River Plant (SRP), Aiken, South Carolina. The PSBF will be used to:

- Estimate the potential of silvicultural energy farms,

- Develop and refine energy crop management practices,

- Evaluate and test speciallzed equipment.

The plan developed by MITRE includes discussions of site selection, layout and design and capital and operating costs.

MITRE has developed designs for two dissimilar areas at the $3 R F$ for establishment of the PSBF. The highly productive "Jackson site" is well suited for hardwood growth while the marginal "Route 278 site" is not. DOE could establish the pilot silvicultural farm at either one or both of these sites to acquire the data to evaluate the concept of silvicultural energy farming.

Design assumptions for the PSBF include:

- 6 year rotations,

- A planting density of 16 square feet per tree or about 2,725 trees per year,

- A projected productivity of 8 Dry Ton Equivalents (DTE) per acre-year.

Tree species to be planted include sycamore (Platanus occidentalis), European alder ( $\Lambda$ lnus glutinosa) and slash pine (Pinus elliottii). The latter will only be planted on a small fraction of the farm. The PSBF will be cultivated, irrigated and fertilized. Irrigation will be provided by a drip irrigation system using well water. The irrigation systeln will also be used to distribute fertilizer. Harvesting will be performed by a new machine presently under development through a DOE sponsored program. The PSBF therefore will provide the opportunity to field test this equipment on a significant scale. 
The target date for the first planting is February 1, 1981. At that time one module (about one-sixth of the farm) will be planted.

The other modules will be planted in succession at one year intervals. Field work, which includes land clearing, site preparation and well installation must be initiated in early 1980 if the target date is to be met. The schedule of operations'leading to the planting of the first module, therefore, must receive special attention.

The total budget for installation and operation of the PSBF (Fiscál Year 1980 to Fiscal Year 2003) is estimated at about $\$ 11$ million (1978 dollars). Uncertainties in some installation and operating costs could bring this total to about $\$ 12.5$ million.

The largest item in the installation costs is the irrigation system followed by land clearing and preparation. The area of greatest uncertainty is land preparation which could cost 50 percent more than the base case.

Operating costs are estimated at about $\$ 9$ million for the 24 year lifetime of the PSBF. This cost could reach $\$ 10.5$ million because of unanticipated cultivation and/or fertilization requirements. Major operating cost items are personnel (about 53 percent), irrigation (about 14 percent) and fertilization (about 10 percent).

The areas of greatest cost uncertainty are associated with operations which will require additional $R \& D$ before final designs for energy farms can be prepared. It is one of the objectives of the PSBF to provide such information.

The cost of producing biomass on the SRP-PSBF was estimated to be $\$ 76 /$ DTE or about $\$ 4.45$ per million Btu for the projected productivity of $8 \mathrm{DTE} / \mathrm{acre-year.} \mathrm{Certain} \mathrm{cost} \mathrm{components} \mathrm{are} \mathrm{not} \mathrm{included}$ in the budget and, therefore, the above cost is not representative of biomass production. cost by energy farm operations.

The Net Energy Efficiency ${ }^{*}$ of the energy farm is about 90 percent. About 60 percent of the total energy consumed to produce the biomass is fuel for the irrigation system.

* Ratio of the net energy yield to the total energy yield. 


\section{INTRODUCTION}

Biomass is one of the fuels being developed by the Department of Energy. (DOE) as a possible substitute for petroleum and natural gas. Biomass is a.clean renewable resource and shows significant potential as a fuel and chemical feedstock. It is currently available in the form of plant and animal residues, food and feed crops and standing timber. The supplies of many of these presently available resources are small, however, and each has other uses. The long-term promise of biomass, therefore, resides primarily in its production on land specifically dedicated to energy farming. These farms will be managed intensively and will produce fuel and chemical feedstocks."

There are several tree species among the promising biomasicrop candidates. These trees will probably be grown on short rotation, but the details of crop management have not yet been thoroughly investigated under field conditions. An extensive R\&D program, therefore, has been planned and is being implemented by DOE to determine the commercial potential of energy farming.

It will be necessary to conduct both the basic research and technology development components of the DOE program concurrently because time constraints prevent a sequential R\&D effort. The development of the first DOE pilot silvicultural biomass farm (PSBF) is an important part of the program and a plan for the establishment and operation of a 1000-acre PSBF at the Savannah River Plant (SRP) near Aiken, South Carolina is the subject of this report. 
It is likely that pilot farms will also be established at other locations across the country and that the experimental field program will be expanded.

The PSBF program will be used to:

- Estimate the potential of silvicultural energy farms;

- Develop and refine energy crop management practices; and

- Evaluate and field test specialized equipment. , MITRE/Metrek has supported the Fuels from Biomass Systems Branch in $2^{u}$

the preparation of a plan which will allow DOE to pursue these objectives at the SRP and the work is summarized under the following major headings:

- Selection of the Savannah River Plant;

- Identification of Sites at the Savannah River Plant;

- Design and Planning Schedule;

- Implementation Plans; and

- Cusl Eslimales ful Iuslallalión alid Operation. 
SELECTION OF THE SAVANNAH RIVER PLANT

The site selected for a PSBF must permit a realistic assessment of the energy farming concept and, therefore, requires the selection of a site which meets specific suitability criteria. These are discussed below.

\section{Suitability Criteria}

Metrek established three basic suitability criteria for. potential energy farm sites during its systems study of silvicuitural energy farms 1 and used these as a guide to identify possible PSBF sites as well.

The three criteria include:

- A minimum of 20 to 25 inches of precipitation annually;

- The availability of arable land; and

- The existence of flat or gradually sloping terrain of less than 30 percent.

The largest quantity of potentially available land which meets these criteria is located in the southeastern United States and the selection of a site within this region was considered desirable. However, because the PSBF will be an experimental facility and will be used to test a wide range of conditions, two additional conditions were also considered to be very important in site selection:

- The availability of water for irrigation; and

- The availability of sites with different production potentials.

IInman, R.E., D.J. Salo, Silvicultural Biomass Farms, Vol. I-VI, MTR No. 7347, MITRE/Metrek, McLean, VA, 1977. 
Management-related conditions which were considered important to the successful establishment and operation of a PSBF included:

- Ease of acquiring needed land;

- Limited public access but easy access to research personnel and contractors;

- Proximity to research facilities and availability of personnel familiar with the site area; and

- Protection of private agricultural and forestry activities.

It was suggested that public (Federal) land should be used for the first PSBF because of the problems associated wi.th acquiring private land to establish and manage such a research facility. Site Recommendation

DOE's Savannah River Plant (SRP) located near Aiken, South Carolina, meets all the criteria for a suitable PSBF site. The location of the site is shown in Figure 1. It is attractive because of its location, size (200,000 acres), multiple-goal land use plan, existing research facilities and staff, and because it is under DOE control. Among the land use goals, the provision of land for energy R\&D activities is particularly important to the proposed cstablishment of a PSBF (ERDA/Savannah River Operations office, 1975). Other advantages of the SRP for a biomass farm are related to the extensive research on-site effort. The scientific and technical expertise available at the Savannah River Laboratory, the Savannah River Ecology Laboratory, the U.S. Forest Service and the National 


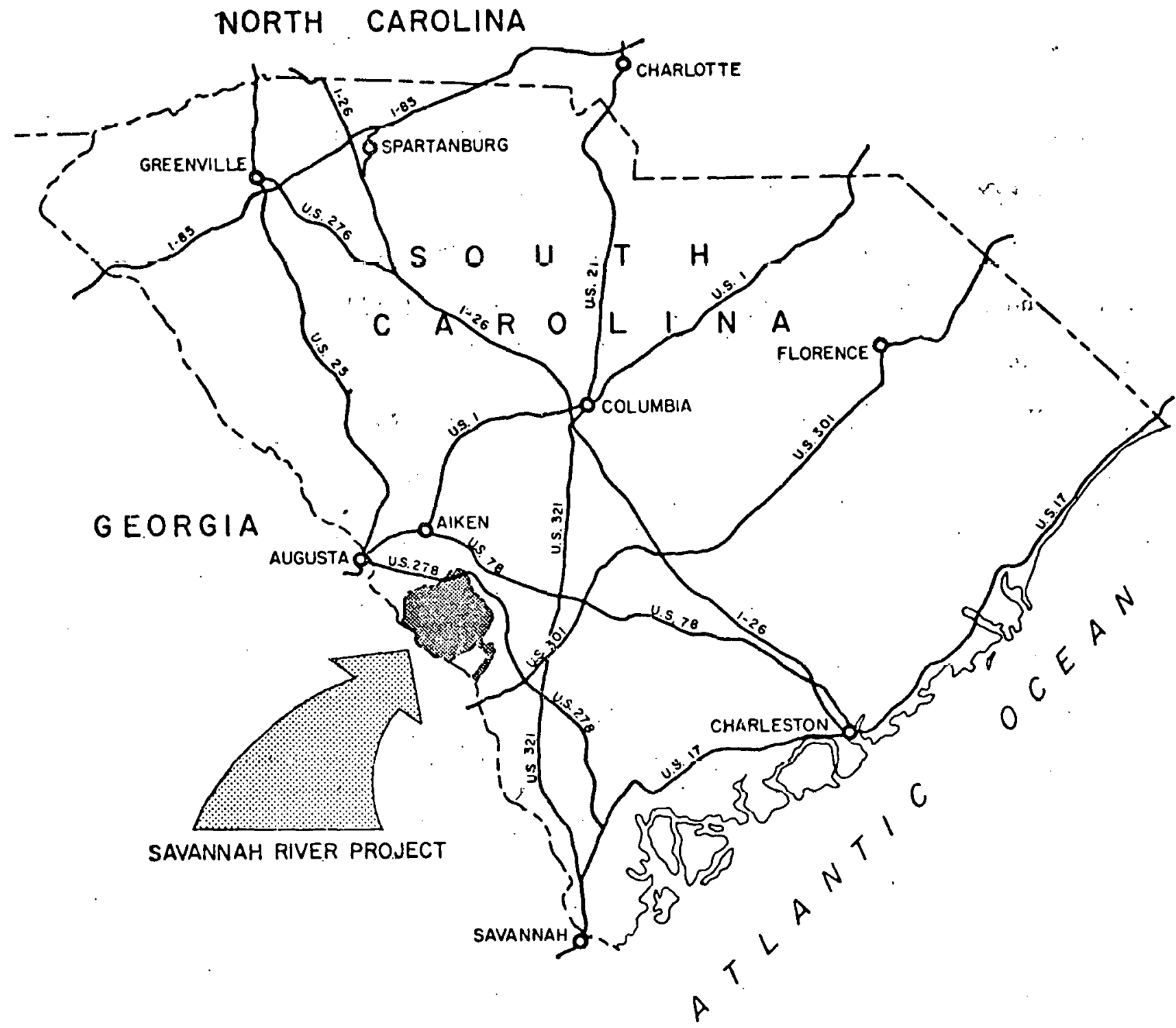

FIGURE 1

LOCATION OF THE SAVANNAH RIVER BLENT 
Environmental Research Park can be used as needed to assist in implementing a valid test of biomass farming. Soils, hydrology and ecology of the 'site'have been described in detail, and work is continuing in these areas. Detailed maps of the site exist.

A few cautionary notes regarding the selection of the SRP are necessary. Because soil fertility on much of the plant site is marginal, the degree of management required to achieve desired levels of productivity may be greater than that required on more fertile sites. It may also be difficult to extrapolate research findings from the SRP to other sites in. the Southeast because of its unique location in the sand hills of the Upper Coastal plain. Finally, although considerable site diversity exists on the SRP, the fragile and unique character of certain portions will preclude their use in the PSBF program. This is particularly true of the low-lying swampy areas. 
IDENTIFICATION OF SITES AT THE SAVANNAH RIVER PLANT

The process of identifying specific sites for the Savannah River Plant-Pilot Silvicultural Biomass Farm (SRP-PSBF) included the development of suitability criteria for site selection, the selection of alternative sites which satisfy the criteria and the designation of two alternative sites. Alternative sites were identified so that the planted acreage can be divided equally between two site-areas which differ significantly in productive potential. This division. will permit evaluation of the energy farming concept over a wider range of conditions than if only one site is used.

The procedure followed to identify alternative sites for the PSBF is summarized below.

Suitability Criteria

The selection of land on the SRP for establishment of the PSBF was based on site quality and diversity and on compatibility of biomass farming with other site uṣes.

Site Quality and Diversity

Site characteristics which were examined to identify potential sites included:

- Soil types and their suitability for hardwood culture;

- Productivity and productive potential;

- Water availability;

- Slope; and

- Diversity. 
The results of a soil survey of the SRP which was conducted in $1970^{1}$ were used to identify suitable sites for the establishment of a PSBF. Of the soil types which the U.S. Forest Service (USFS) considers "well suited" for hardwoods, only the upland sites were retained for further evaluation. Bottomland soils are in areas which cannot be managed intensively because of environmental and operational problems. Aréas with soil types either "moderately" or "poorly suited" for hardwood growth, according to the USFS, were also identified.

The USFS has divided the SRP into 90 timber compartments and has prescribed timber management practices for each compartment. The productivity data reported in the compartment prescriptions were combined with soil information to estimate the potential suitability of candidate site areas for hardwood culture. Productivity class values and site indices from each prescription were used as the quantitative base for this assessment ${ }^{2}$.

Irrigation will be used to supplement natural precipitation. The PSBF, therefore, will include both mesic and relatively xeric sites. Bottomland hardwood sites will not be included because of constraints imposed by wetness and topography.

\footnotetext{
1Aydelott, D.G., 1971, Soils of the Savannah River Project, Aiken, South Carolina, U.S. Forest Service, Southern Region.

2Pitts, R.W., 1976, Timber Management Plan: Savannah River Plant, U.S. Forest Service, Savannah River Plant, Aiken, SC.
} 
Mechanical harvesting systems are being developed for use on biomass farms with slopes up to about 30 percent (17 degrees). Land with slope greater than this should not be considered for PSBF use. In any event, a review of U.S. Geological Survey maps indicated that most of the land on the SRP has acceptable slope.

Commercial biomass farms will be established on a variety of sites, some of which will include "marginal" land. The SRP-PSBF will provide an opportunity to assess the potential of both arable and marginal site-types if diverse areas are chosen. The first PSBF, thoroforc, will be located on two veiry differeul 500- tu 600acre sites. One of these will be chosen because of its suitability for hardwood culture and the other because of its limited potential using conventional practices. Both sites will be managed intensively.

\section{Compatibility of the PSBF with Other SRP Activities}

The Savannah River Plant Land Use $\mathrm{Plan}^{1}$ defined several goals for land use at the SRP. The installation of a biomass farm is consistent with one of these goals, which is, "to provide land for energy research and development activities." In recognition of the multiple land use philosophy established by the plan, however, alternative PSBF sites were selected to:

- Avoid nuclear production areas;

- Avoid interference with experimental programs of the Savannah River Laboratory, Savannah River Ecology Laboratory,

\footnotetext{
${ }^{1}$ Savannah River Plant Land Use Plan, 1975, ERDA/Savannah River Operations office, Aiken, SC.
} 
U.S. Forest Service, and the National Environmental Research Park;

- Avoid interference with other Department of Energy R\&D projects;

- Limit impact on the existing timber management program; and

- Avoid sites colonized by the red-cockaded woodpecker, a protected species.

Appropriate alternative sites, therefore, were selected after:

- Discussions with SRP Environmental Activities Branch and USFS personnel;

- A review of SRP site use permits and site use applications (SRP Form SR-88); and

- A mapping of restricted areas, research activities, timber stands, and known woodpecker colonies.

A site use application for the recommended areas has been filed with the SRP Environmental Activities Branch. Current site users are reviewing the application. It is anticipated that many of the research activities for which land is currently dedicated will be completed by the time work begins on the PSBF. Most of the on-going site use permits and many of the new ones have been issued for activities in nuclear production areas. These areas will be avoided and should not present a problem to the PSBF program.

An effort was made to locate biomass farm sites outside the "security control area" of the plant. This was done to provide easy access to contractors, researchers and authorized visitors. 
Selection of Alternative Sites

The criteria discussed in the previous section were used to select four alternative site areas for the establishment of the PSBF.

The selected areas are located in timber compartments 3 (Jackson site), 23 (Route 278 site), 37 (Meyers Mill site) and 42 (Baxley Road site). Each area is indicated in Figure 2. The characteristics of each area are summarized below, and in Table I. It is important to emphasize that these are representative characteristics of the site areas in general and not all of them apply to the specific $500-600$ acre sites ultimately recommended within these areas. Jackson Site Area

- Fertile soil suitable for upland hardwoods

- High productive potential

- Sufficient water generally available*

- Nearly level terrain

- Remote from nuclear production facilities

- No conflict with other research projects

- Currently forested with considerable slash pine which is considered a lcss desirable commercial crop at SRP than loblolly pine and longleaf pine

- Remote from red-cockaded woodpecker colonies

- Accessible to contractors, researchers and authorized visitors

The Jackson site is somewhat atypical of other SRP locations because of its potentially high productivity. It would, therefore, *Drought periods occur annually and supplemental water may be required during stand establishment. 


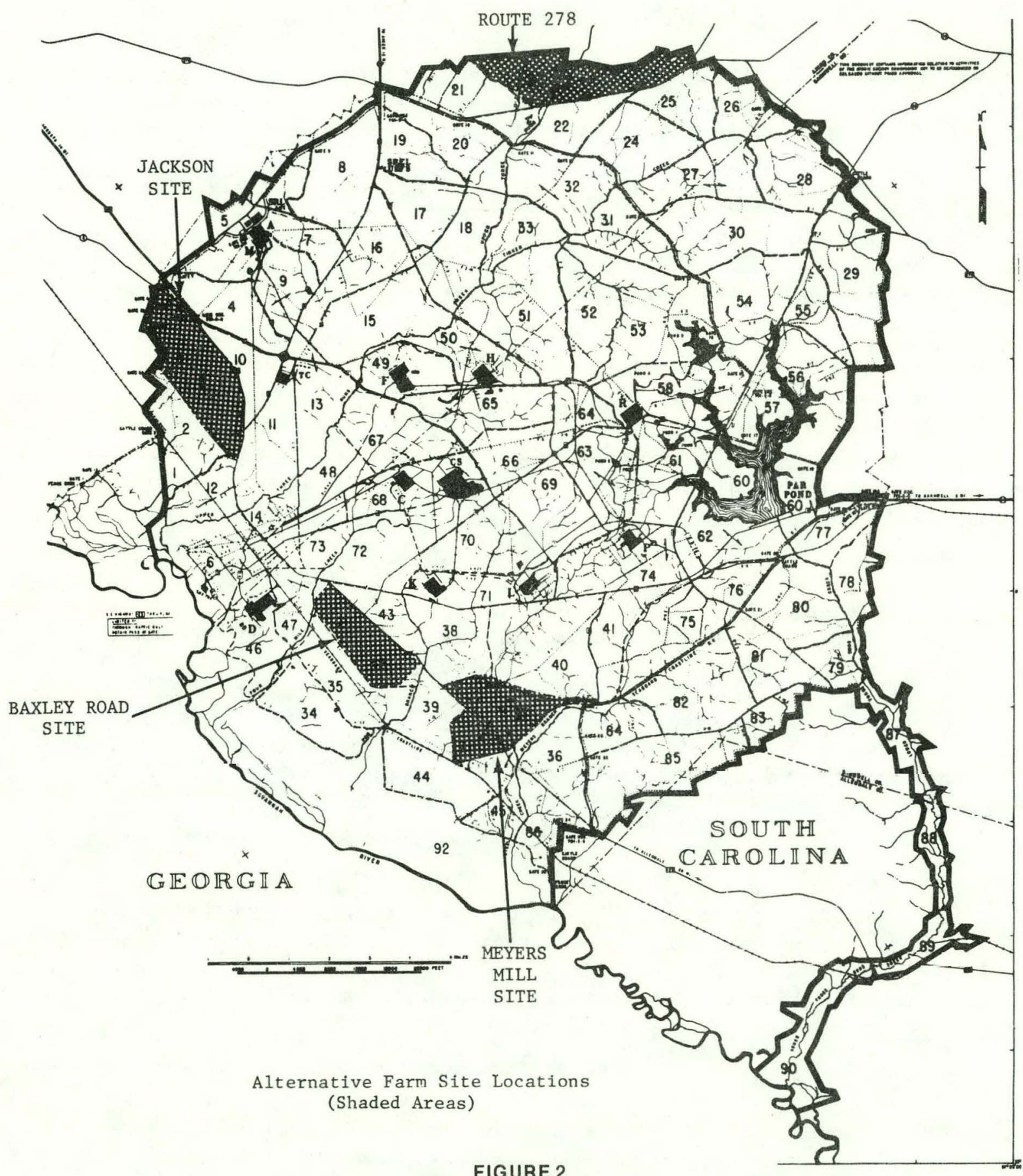

FIGURE 2

LOCATION OF TIMBER COMPARTMENTS CONTAINING ALTERNATIVE SITES FOR A PILOT SILVICULTURAL BIOMASS FARM AT THE SAVANNAH RIVER PLANT 
TABLE I

CHARACTERISTIICS OF POTENTIAL SRP-PILOT SILVICULTUPAL BIOMASS FAZM SITES

\begin{tabular}{|c|c|c|c|c|c|c|c|c|c|c|}
\hline SITE & $\begin{array}{l}\text { TTMBER } \\
\text { COMPARTMENT }\end{array}$ & $\begin{array}{l}\text { TIMPER } \\
\text { STAND }\end{array}$ & $\begin{array}{l}\text { TIMBER } \\
\text { GROP }\end{array}$ & $\begin{array}{l}\text { APPROXIMATE } \\
\text { STAND AREA } \\
\text { IN SITE AREA } \\
\text { (ACRES) }\end{array}$ & $\begin{array}{l}\text { STAND AGE } \\
\text { (YEARS) }\end{array}$ & $\begin{array}{l}\text { SITE INDEX } \\
\text { (AGE S0) }\end{array}$ & $\begin{array}{c}\text { SAWTIMBBER PROD,CTIVITY } \\
\text { (BOARD FT/Y:AR) }\end{array}$ & $\begin{array}{l}\text { SRP PRODUCTIVITY } \\
\text { CLASS }\end{array}$ & $\begin{array}{l}\text { REPRESENTATIVE } \\
\text { MAJOR SOIL } \\
\text { GROUPS }\end{array}$ & REMARKS \\
\hline Jackson & 3 & $\begin{array}{r}1 \\
2 \\
4 \\
5 \\
6 \\
13\end{array}$ & $\begin{array}{l}\text { Slash Pine } \\
\text { Mixed Hardwoods } \\
\text { Mixed Hardwoods } \\
\text { Loblolly Pine } \\
\text { Slash P1ne } \\
\text { Loblolly Pine }\end{array}$ & $\begin{array}{r}500 \\
20 \\
50 \\
70 \\
130 \\
40\end{array}$ & $\begin{array}{l}23 \\
50 \\
24 \\
22\end{array}$ & $\begin{array}{l}90 \\
60 \\
90 \\
90 \\
70 \\
80\end{array}$ & $\begin{array}{l}500-600 \\
100-150 \\
500-600 \\
500-600 \\
250-300 \\
300-400\end{array}$ & $\begin{array}{r}\text { I } \\
\text { IV } \\
\text { I } \\
\text { I } \\
\text { III } \\
\text { II }\end{array}$ & $\begin{array}{l}\text { Kalmia, Johns, } \\
\text { Grady, Bay- } \\
\text { boro }\end{array}$ & $\begin{array}{l}\text { Excellent Hard- } \\
\text { wood Site, } \\
\text { Easily } \\
\text { Accessible }\end{array}$ \\
\hline Route 278 & 23 & $\begin{array}{l}1 \\
2 \\
3 \\
5\end{array}$ & $\begin{array}{l}\text { Longleaf Pine } \\
\text { Loblolly Pire } \\
\text { Slash P1ne } \\
\text { Mixed Harducods }\end{array}$ & $\begin{array}{r}230 \\
70 \\
240 \\
240\end{array}$ & $\begin{array}{r}12 \\
19 \\
19 \\
4\end{array}$ & $\begin{array}{l}60 \\
60 \\
80 \\
80\end{array}$ & $\begin{array}{l}100-150 \\
100-150 \\
300-400 \\
200-250\end{array}$ & $\begin{array}{l}\text { IV } \\
\text { IV } \\
\text { II } \\
\text { III }\end{array}$ & $\begin{array}{l}\text { Troup Sand, } \\
\text { Terrace Troup } \\
\text { Sand, Kalmia, } \\
\text { Johns }\end{array}$ & $\begin{array}{l}\text { Variable Site } \\
\text { Easily } \\
\text { Accessible }\end{array}$ \\
\hline Meyers Mill & 37 & 1 & Longleaf P1re & 600 & 21 & 80 & $300-400$ & II & $\begin{array}{l}\text { Terrace Troup } \\
\text { Sand, Foquay, } \\
\text { Wagram }\end{array}$ & $\begin{array}{l}\text { Moderately Pro- } \\
\text { ductive Site, } \\
\text { Not Easily } \\
\text { Accessible }\end{array}$ \\
\hline Baxley Road & & $\begin{array}{l}4 \\
6 \\
7 \\
8 \\
9\end{array}$ & $\begin{array}{l}\text { Slash Plne } \\
\text { Mixed Hardwcods } \\
\text { Slash Pine } \\
\text { Slash Plne } \\
\text { Slash Pine }\end{array}$ & $\begin{array}{r}200 \\
50 \\
70 \\
40 \\
90\end{array}$ & $\begin{array}{l}20 \\
50 \\
20 \\
20 \\
28\end{array}$ & $\begin{array}{l}70 \\
90 \\
70 \\
80 \\
80\end{array}$ & $\begin{array}{l}250-300 \\
250-300 \\
250-300 \\
3000-400 \\
300-400\end{array}$ & $\begin{array}{r}\text { III } \\
\text { III } \\
\text { III } \\
\text { II } \\
\text { II }\end{array}$ & $\begin{array}{l}\text { Terrace Troup } \\
\text { Sand, Grady, } \\
\text { Bayboro }\end{array}$ & $\begin{array}{l}\text { Moderately Pro- } \\
\text { ductive Site, } \\
\text { Not Easily } \\
\text { Accessible }\end{array}$ \\
\hline
\end{tabular}


provide the greatest contrast to a less productive site.

\section{Route 278 Site-Area}

- A mixture of fertile and infertile soils with a wide range of suitability for upland hardwoods

.. Low to moderate productive potential

- Relatively arid site with sandy soils

- Relatively level terrain

- Remote from nuclear production facilities

W.e. No conflict with other research projects

- Currently forested with longleaf pine, slash pine and mixed hardwoods; possible conflict with current management plans involving present stand of longleaf pine.

- Remote from red-cockaded woodpecker colonies

- Accessible to contractors, researchers and visitors

The Route 278 site is generally less productive than other candidate areas. It wnild provide an orecllent contrast lu lie highiy productive Jackson site.

\section{Meyers Mill Site}

- Predominantly fertile soil suitable for upland hardwoods

- Moderately productive potential

- Sufficient water generally available

- Nearly level terrain

- Remote from nuclear production facilities

- No conflict with other research projects 
- Potential conflict with current forest management plans because it is forested with 20-year-old longleaf pine, a preferred species

- Remote from red-cockaded woodpecker colonies

- Less accessible to contractors, researchers and visitors because it is inside the security control area

The Meyers Mill site is relatively productive. However, because it is forested with 20-year-old longleaf.pine and is not readily accessible, it is a less desirable location.

Baxley Road Site

- Predominantly fertile soils suitable for upland hardwoods

- Moderately productive potential

- Sufficient water generally available

- Nearly level terrain

- Remote from nuclear production

- No conflict with other research projects

- Currently forested with slash pine and some mixed hardwoods

- Red-cockaded woodpecker colonies in the timber compartment but not in the site area

- Less accessible to contractors, researchers and visitors

The site is not as accessible to contractors, researchers and visitors because it is located well within the security control area. This is its most serious limitation as a potential PSBF site.

\section{Site Area Recommendation}

Each of the sites described above is potentially suitable for PSBF use. However, a joint Jackson (Timber Compartment 3) and Route 
278 (Timber Compartment 23) site is recommended above any other combination. Hardwoods and some softwoods would be established on approximately 500 acres in each area. Planting these two sites should provide a test of the biomass farm concept because the Jackson site is highly productive and will be difficult to manage, whereas the Route 278 site is only marginally productive, but should be much easier to manage. Together, the two locations provide considerable site diversity. Furthermore, both sites are readily accessible to contractors, researchers and visitors because they are located outside the security control area.

The Meyers Mill and Baxley Road sites are both moderately pro-. ductive areas and do not provide the contrasts of the combined Jackson/Route 278 option. The Meyers Mill site is also forested with a prime stand of longleaf pine and should be left undisturbed, if possible. Both the Meyers Mill and Baxley Road sites are located well inside the security fence and would present access problems to outsiders.

Therefore, the Jackson site (Timber Compartment 3) and the Route 278 site (Timber Compartment 23) are presented to the Department of Energy and to SRP management for consideration as PSBF sites, and the following plan is presented for their development. 
DESIGN AND PLANNING OF THE PILOT SILVICULTURAL BIOMASS FARM

The general features of the proposed pilot silvicultural biomass farm at the Savannah River Plant are based on conceptual designs developed by MITRE/Metrek during its systems study of silvicultura! energy farms.1 It was necessary to use this approach because much of the information obtained from field experience is currently limited to relatively small experiments. This situation will change during the course of the SRP-PSBF program and many of the currently envisioned PBBF operalions will be müdified accordingly. It is neceosary, therefore, to consider the PSBF design plan presented here as flexible and subject to change as new information becomes available. $\underline{\text { PSBF Design Plan }}$

Capital and $O \& M$ costs have been estimated for the installation and operation of a PSBF at the SRP. These "base" cases reflect currently planned levels of management for the SRP-PSBF. The range of uncertainty associated with each base case has been indicated by a "low" case and a "high" case surrounding each base case. These low and high cases reflect the range of data obtained from available sources.

Size and Layout

The PSBF will consist of 1,000 planted acres about equally divided between the Jackson and Route 278 sites. Each site is

IInman, R.E., D.J. Salo, "Silvicultural Biomass Farms," Vol. I-VI, MTR Number 7347, MITRE/Metrek, Mclean, VA., 1977. 
considered large enough to provide the data desired, but could be increased at the request of DOE. Additional acreage has been allocated for biomass storage, experimental test plots, work and access roads and irrigation lanes. The total area required is estimated to be about 1,100 acres. The locations of the proposed Jackson and Route 278 sites within their Timber Compartments are shown in Figures 3 and 4 , respectively. Each site has features which influence its layout.

\section{Jackson Site}

An inspection of the Jackson site revealed the presence of seven small and two extensive wet areas which are interconnected by an irregular system of old drainage ditches. In their present condition these drainage ditches are essentially nonfunctional, but they could be reconditioned to provide adequate drainage for the wet areas of the farm.

The proposed layout of the six annual modules and research and storage areas at the Jackson site are shown in Figure 5. The module layout is arranged to avoid wet areas. Figure 5 includes the location of reconditioned drainage ditches and of work roads. The major features of the site are summarized in Table II. Each annual module is characterized by its planted area and by the length of work roads required to service the module. The first module will require proportionally more roads than modules installed subsequently, because some of the roads will be shared by other modules. Roads servicing 


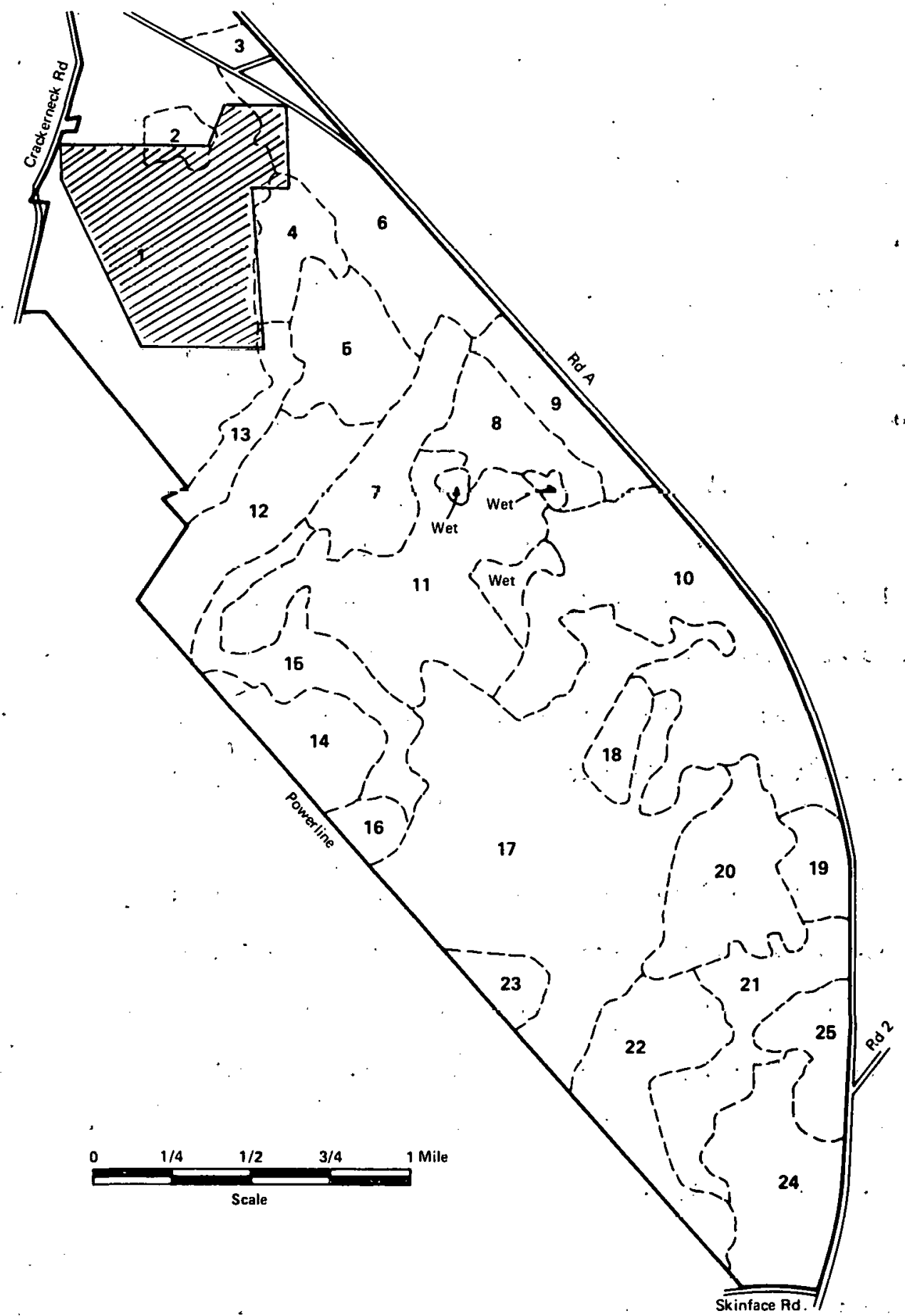

TIMBER COMPARTMENT 3

FIQURE 3

LOCATION OF THE JACKSON SITE-PILOT SILVICULTURAL

BIOMASS FARM 


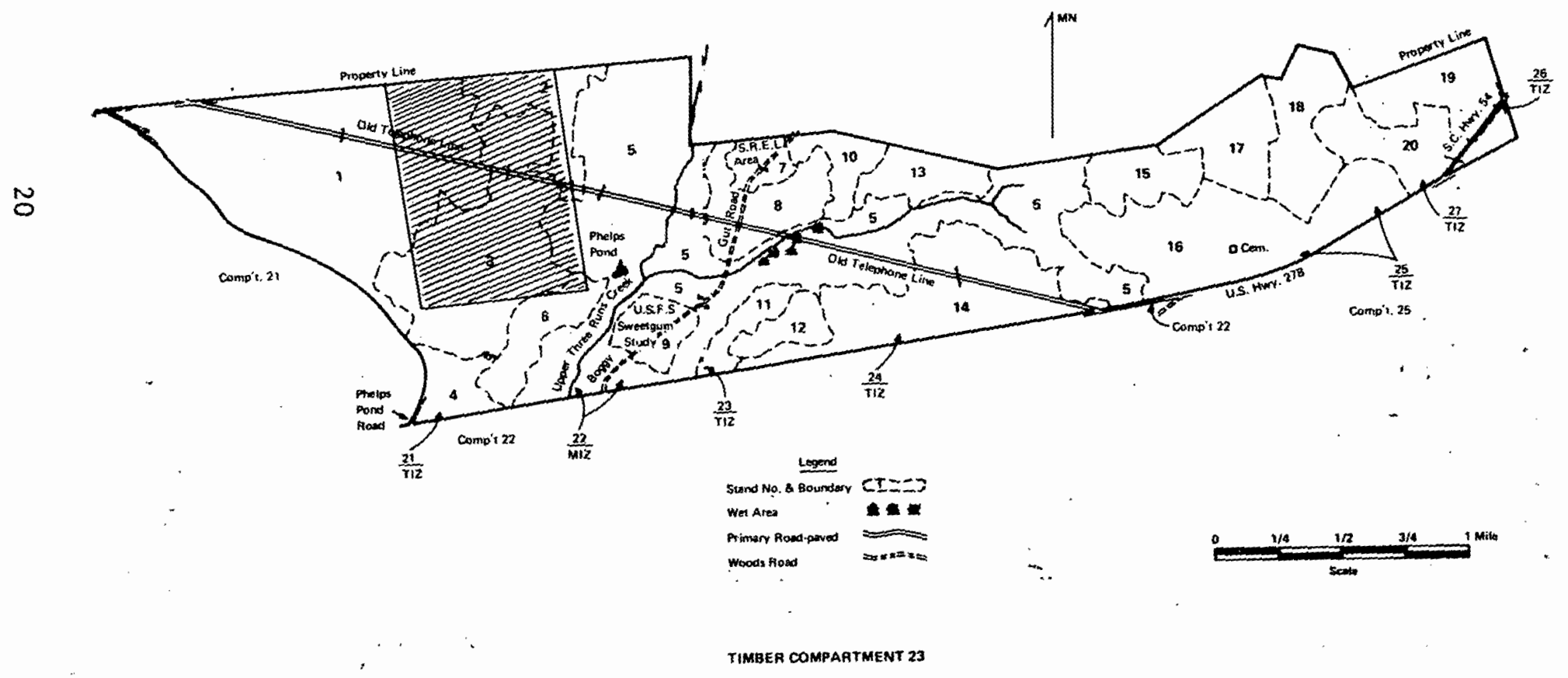
FIGUAE 4
LOCATIO 4 OF THE ROUTE 278 SITE-PHLT SILVICULTURAL
GIOMASS FARM 


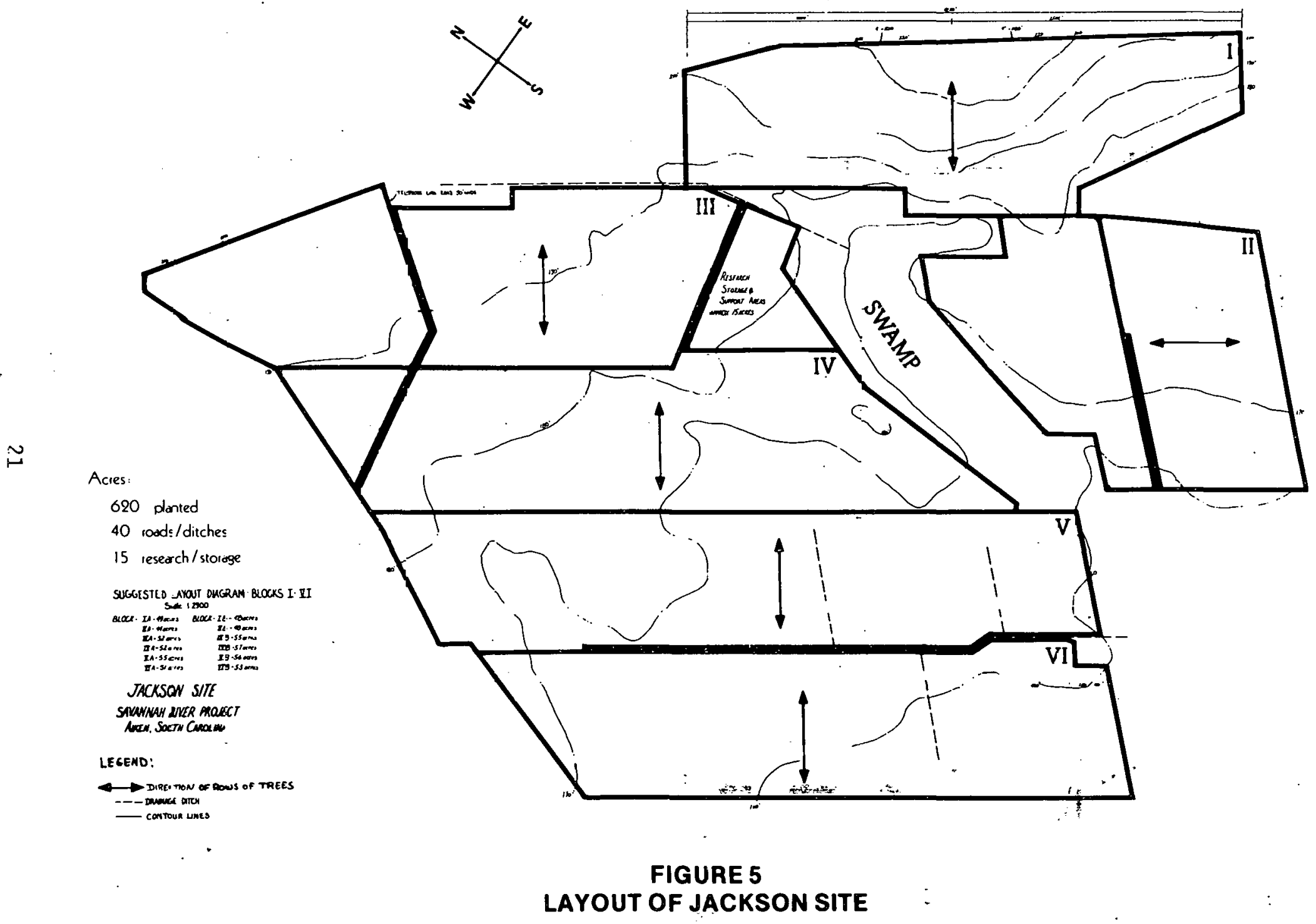


TABLE II

SITE CHARACTERISTICS OF THE PILOT SILVIGULTURAL BIOMASS FARM

JACKSON SITE

\begin{tabular}{|c|c|c|c|c|c|c|c|}
\hline Annual Module & I & II & III & IV & $\mathrm{V}$ & VI & Total \\
\hline $\begin{array}{l}\text { Planted area (acres) } \\
\text { Road area (acres) } \\
\text { Storage \& research area (acres) }\end{array}$ & $\begin{array}{c}97 \\
9(1) \\
15\end{array}$ & $\begin{array}{r}92 \\
7 \\
-\end{array}$ & $\begin{array}{r}107 \\
7 \\
-\end{array}$ & $\begin{array}{r}109 \\
6 \\
-\end{array}$ & $\begin{array}{r}111 \\
6 \\
-\end{array}$ & $\begin{array}{r}104 \\
4 \\
-\end{array}$ & $\begin{array}{r}620 \\
39 \\
15\end{array}$ \\
\hline Total site area (acres) & 121 & 99 & 114 & 115 & 117 & 108 & 674 \\
\hline $\begin{array}{l}\text { Road length (feet) } \\
\text { Ditches length (feet) }\end{array}$ & $\begin{array}{r}16,000 \\
4,160\end{array}$ & $\begin{array}{r}11,600 \\
1,780\end{array}$ & $\begin{array}{c}11,500 \\
-\end{array}$ & $\begin{array}{c}9,900 \\
-\end{array}$ & $\begin{array}{r}11,200 \\
5,950\end{array}$ & $\begin{array}{r}6,800 \\
14,900\end{array}$ & $\begin{array}{l}67,000 \\
26,790\end{array}$ \\
\hline
\end{tabular}

ROUTE 278, SITE

\begin{tabular}{|l|r|r|r|r|r|r|r|}
\hline Annual Module & I & II & III & IV & V & VI & Total \\
\hline Planted area (acres) & 63 & 63 & 63 & 63 & 63 & 63 & 378 \\
Road area (acres) & $7(1)$ & 4 & 4 & 4 & 4 & 4 & 27 \\
Storage \& research area (acres) & 10 & - & - & - & - & - & 10 \\
\cline { 2 - 7 } Total site area (acres) & 80 & 67 & 67 & 67 & 67 & 67 & 415 \\
\hline
\end{tabular}

TOTAL

\begin{tabular}{|l|r|r|r|r|r|r|r|}
\hline Annual Module & I & II & III & IV & V & VI & Total \\
\hline $\begin{array}{l}\text { Planted area (acres) } \\
\text { Road area (acres) }\end{array}$ Storage \& research area (acres) & 160 & 155 & 170 & 172 & 174 & 1.67 & 998 \\
Total PSBF area (acres) & 25 & - & - & - & - & - & 25 \\
\cline { 2 - 7 } Road length (feet) & 201 & 166 & 181 & 182 & 184 & 175 & 1089 \\
Ditches length (feet) & 26,400 & 11,604 & 16,600 & 15,000 & 16,300 & 11,900 & 97,304 \\
\hline
\end{tabular}

(1) Includes roads for storage and research area. 
the storage and research areas are included in the Module I road system. Drainage ditches will be cleared in each module as required.

As shown in Figure 5, some contour changes are observed between various parts of Module I. These contour changes were considered in the design of the irrigation system for that module. Dirt roads provide access to the Jackson site from a paved surface.

\section{Route 278 Site}

The proposed layout of the six annual modules and research and storage area at the Route 278 site are presented in Figure. 6. Table II summarizes the major characteristics of the site. A dirt road provides access from Route 278 .

Rotation Period and Annual Modules

A 6-year rotation schedule was selected for both seedling and coppice crops. Accordingly, the planted areas at each site are divided into six approximately equal modules which will be installed annually in succession.

\section{Biomass Crop}

Sycamore (Platanus occidentalis $\underline{\text { L. }}$ ) and European Black Alder (Alnus glutinosa) are proposed as hardwood species for the SRP-PSBF. Half of the sycamore will be planted on one-half of Modules III-VI and alder on the other half. In addition, a softwood species will be included with the two hardwoods on two modules at each site. Onefourth of Modules I and II will be planted with slash pine (Pinus elliottii Engelm. var. elliottii). Inclusion of a pine species on 


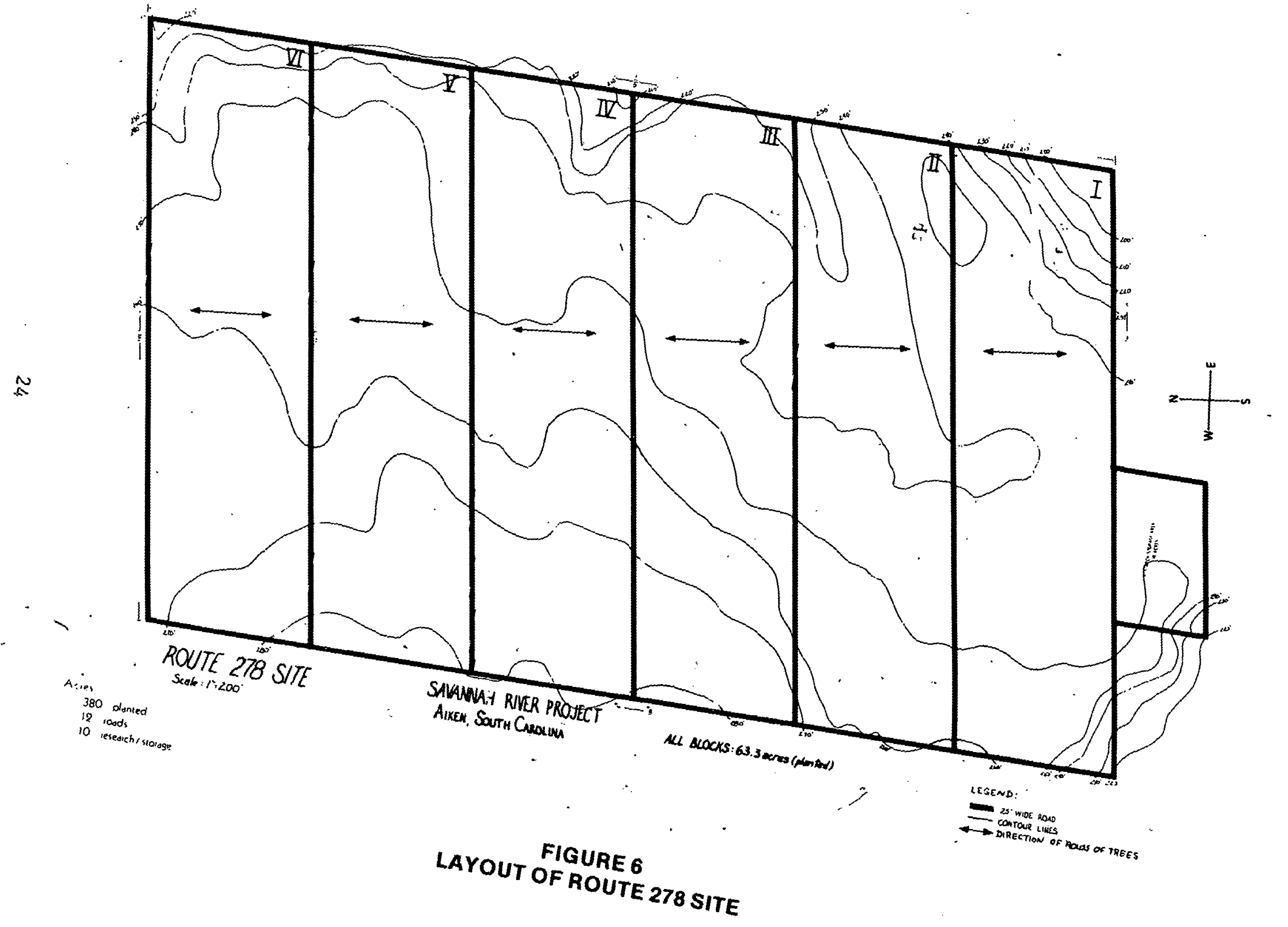


the PSBF will permit a ccuparison of identically managed hardwoods and softwoods.

\section{Planting Density and Planting Pattern}

A planting density of 2,725 trees per acre $\left(16 \mathrm{ft}^{2} / \mathrm{tree}\right)$ is suggested for all modules. Seedlings will be planted 2 feet apart in rows 8 feet apart rather than in $4^{\prime} \times 4^{\prime}$ rows, to reduce irrigation system costs. It is not expected that this change from the more common $4^{\prime} \times 4^{\prime}$ pattern of planting will significantly affect the projected productivity at the eite.l

\section{Irrigation/Fertilization Needs}

The two major options for irrigation of the PSBF are the traveller and the trickle systems. A trickle system is proposed because:

- A traveller system is already being used in energy farm research at the University of Georgia and by the U.S. Forest Service in Rhinelander, Wisconsin. Therefore; use of the trickle system on the PSBF will permit comparison of the two systems;

- The trickle system will be easier to manage and operate on a day-to-day basis and require lower operation/management $(O / M)$ costs;

- About 5 percent more acreage at a given site can be planted to an energy crop if a trickle system is used rather than a traveller system; and

- Less water is required with this system than with the traveller system. Nutrient losses are lower when fertilizer is applied with a trickle system than with a traveller system.

The capital cost of the trickle system, however, is greater than that of the traveller system. This higher cost is due, in large

$1_{\text {Robert Heeren, Union Camp Corporation, Frank1in, VA, personal }}$ communication, June 1978 . 
part, to the cost of materials such as plastic tubing. This tubing must be installed along each row of seedlings and the capital cost of the tubing - is approximately $\$ 450$ per acre when a $4^{\prime} \times 4^{\prime}$ spacing is used.1 The capital cost of the tubing can be reduced to around $\$ 270$ per acre by using a $2^{\prime} \times 8^{\prime}$ planting pattern. This cost is roughly.comparable to that of a traveller system.

Disadvantages of the trickle system include a need to replace the plastic tubing after each rotation because of damage and plugging. Caution is also required to prevent breakage of the tubing by weed cultivators.

\section{Fertilization}

Liquid fertilizer will be applied through the trickle irrigation system. This method of fertilization will help to reduce the O\&M costs of the farm.

\section{Productivity}

Metrek has estimated biomass productivity at a hypothetical site located in Hancock County, Georgia, about 75 miles from the SRP. 2 Based on local climate and soil characteristics, it was determined that a biomass farm planted with hardwoods such as sycamore could produce about 8 dry ton equivalents (DTE) per acre-year if managed

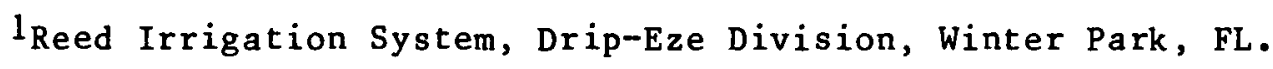
${ }^{2}$ Salo, D.J., R.E. Inman, "Silvicultural Biomass Farms, Land Suitability and Availability," Vol. III, MTR-7347, MITRE/Metrek, McLean, VA., May 1977.
} 
intensively. The growing conditions at the SRP are similar to those of this hypothetical site. A productivity of 8 DTE acre-year was therefore assumed for base case considerations at the "SRP-PSBF. Productivities are expected to vary between 5 DTE per acre-year (10w case) and 10 DTE per acre-year (high case).

The characteristics of the biomass farm adopted as the base case for the design of the PSBF are summarized in Table III. Overa11..Planning Schedule

An installation and operations schedule for the SRP-PSBF is presented in Figure 7. All years presented in the figure are:calendar years. It is assumed that selection of a contractor will begin in late 1979, and that site preparation will be initiated in 1980 . This schedule is necessary if the first seedlings are to be planted during early 1981. Failure to follow this schedule will delay the first planting until early 1982.

Site clearing and preparation and planting are scheduled at oneyear intervals for the first six years. One module will be cleared and planted annually at each site beginning with the clearing of Module I in 1980. Partial replanting of Modules I and II will be required after harvest of these modules because slash. pine is not. a coppicing species.

Field operations such as weed control, irrigation, fertilization, and maintenance will be required annually, but not necessarily on all modules. 
TABLE III

DESIGN CHARACTERISTICS OF THE PILOT SILVICULTURAL RIOMASS FARM

\section{ITEMS}

Total planted area

Total area with roads; storage, etc.

Rotation period (initial and coppice growth)

Number of annual modules

Planting density

Area per tree

Planting pattern:

Distance between rows

Distance between trees

Irrigation

Fertilization

Species

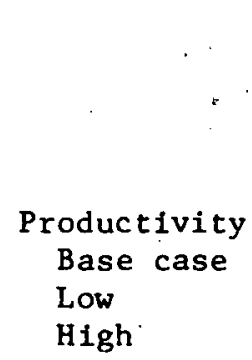

$\because$

UNITS

Acres

Acres.

Years.

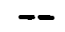

$$
\begin{gathered}
\text { Trees/acre } \\
\mathrm{ft}^{2} / \text { tree }
\end{gathered}
$$

ft

ft
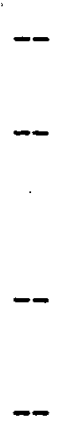

$-$

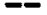

$$
\begin{aligned}
& \text { DTE } / a-y \\
& \text { DTE } / a-y \\
& \text { DTE } / a-y
\end{aligned}
$$

VALUE

1,000

1,100

6

6

2,725

16

8

Trickle system and well water

Liquid fertilizer applied through irrigation system

American sycamore (platanus occitentalis)

European Alder

(Alnus glutinosa)

Slash pine (rinus

elliottii Engelm. var. elliottii) (i)

8
5
10

\footnotetext{
(1) Planted only on one-fourth of the areas of modules I and II at both sites.

${ }^{(2)}$ Dry Ton Equivalent per acre-year.
} 


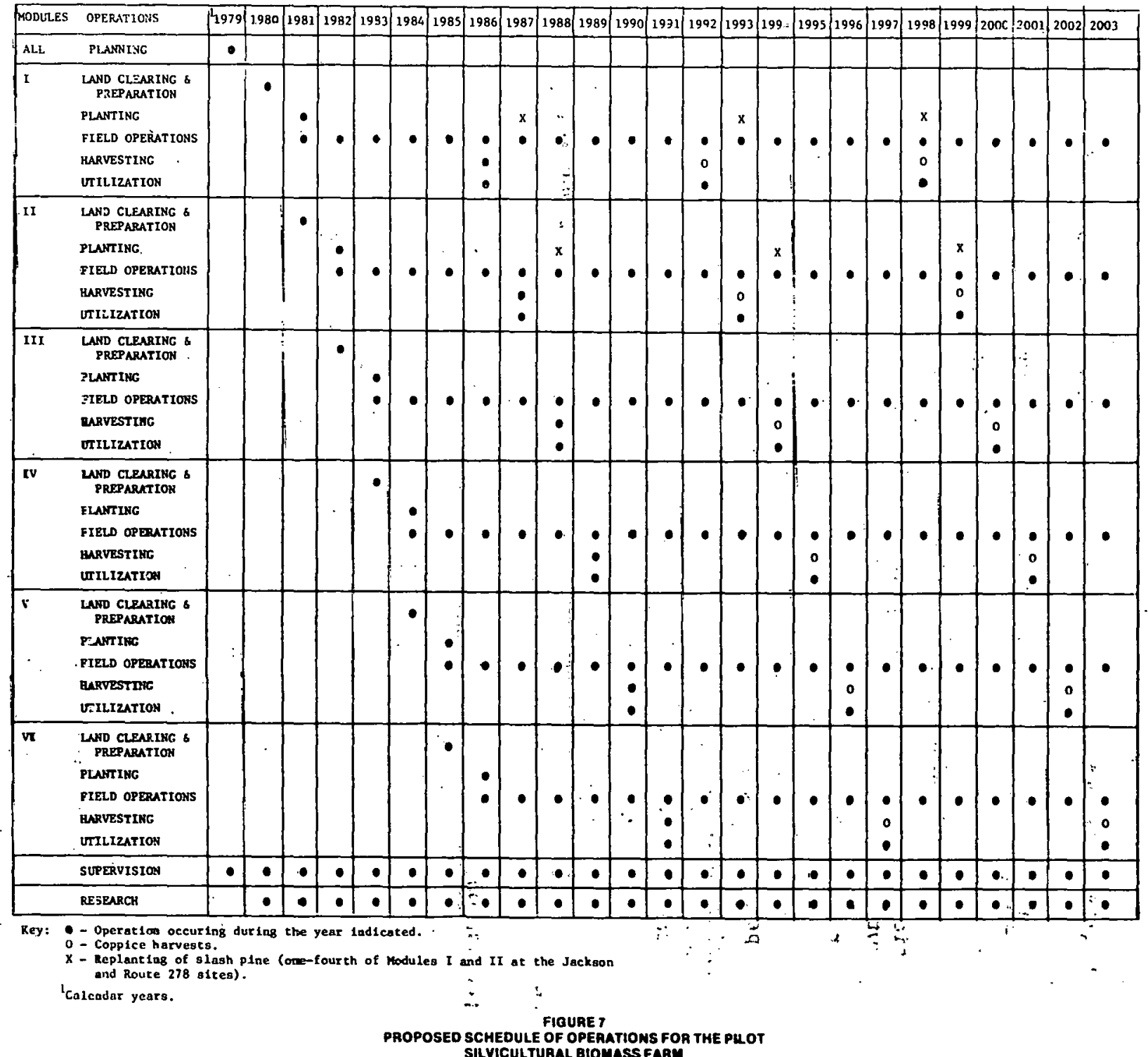


One module at each site will be harvested annually starting in late 1986 when Module I will reach the ends of the first six-year rotation. Research and supervision will be ongoing operations throughout the life of the farm.

It is proposed that, at a minimum, the lifetime of the PSBF include one seedling and two full coppice rotations. This would require funding until the year 2003. At that time a decision could be made to:

- Pursue the experiment indefinitely;

- Pursue the experiment for three coppice rotations.of Modules I and II, i.e., until the year 2005.' At this point Module II will also have reached almost three full coppice rotations; or

- Interrupt the experiment in 2003 and harvest all modules to obtain yield data at various stages of coppice growth.

The base case for the planning of the PSBF operation assumes that the experiment will be pursued until 2003, a period of 24 years. Biomass Farm Installation.

The installation of the PSBF includes the following steps, in approximate order: surveying, land clearing, land preparation, drainage ditching if needed, access and work road construction, utility installation if required, irrigation system.installation, and planting. These operations are discussed below. For each of the operations, local or regional contractors were contacted and asked to estimate the cost of the operation. The technical and cost data supplied by these operators were used in designing and costing the 
installation of the farm. The data gathered through these contacts are presented in the Appendix.

\section{Surveying}

This operation will be conducted in two stages: the initial survey of the two sites and marking of the annual modules; and, after the land has been cleared, staking out of the work roads, research areas, buildings and wells. The required work can be performed at cost by SRP personnel, Contract and Service Division. No significant lead trme is needed to iniliale lie work. The duration of the survey is two weeks per site. Survey of individual modules will require two weeks. See Appendix, Section 1 for details of this operation.

\section{Land Clearing}

Site clearing refers to the removal of timber presently growing on the land. The preferred method of clearing is by a timber sale because it provides the higest dollar return to the government. In a timber sale, the quantity and market value of the trees to be sold are estimated by the Forest Service (Appendix, Section 2). The sale is then advertised; bids are submitted and a contractor is selected. Contracts are negotiated with the Contract and Services Division of the Savannah River Plant. The total time required for a timber sale from initiation through the completion of harvest varies from 15-24 months. A fifteen-month period was adopted for planning purposes. 
A faster method of land clearing is the salvage sale. Salvage contracts are negotiated with local contractors on the basis of a standard price per load of wood removed. The return to the Government is lower, but the entire operation for a 200-acre tract can be completed in about six months.

A third method of clearing engages local operators to dispose of standing timber. The estimated cost of this method is about $\$ 80$ per acre (base case), but can range from $\$ 65$ (1ow case) to $\$ 150$ (high case) per acre. However, the job can be completed in about four to six weeks (see Appendix, Section 3).

In order to meet the February 1, 1981 planting deadline for Module I, it is recommended that it be cleared through a salvage sale (Option 1) or through clearing without recovery (Option 2). Modules II-VI will be cleared through timber sales. The base case data used in planning for land clearing are presented in Table. TV.

\section{Land Preparation}

After the land is cleared, the modules will be root-raked, the stumps and slash will be burned, the ash residue will be spread on the land and the area will be disked. In addition to preparing the soil for planting, disking will level the ground and fill holes and old ditches.

It is estimated that land preparation will cost $\$ 200$ per acre. The data base used for this estimate is presented in the Appendix, Section 3. The prices quoted by contractors operating in South 
DATA BASE FOR LAND CLEARING

OF THE PILOT SILVICULTURAL BIOMASS FARM

ITEM

UNITS

VALUE

Land Clearing

1. Timber Sale (1)

Duration per module

Cost: to project $(4)$

Months $\quad 15$

2. Salvage Sale (2)

Duration per module

Cost to project (4)

Months 6

$\$ \quad \therefore \quad 0$

3. C.jear rutting (3)

Duration per module

Cost to project

Base case

$\$$

0

Low case

High case

Weeks b

$\$$ /acre $\quad 80$

\$/acre.: : $\quad 65$

\$/acre $\quad 150$

(1) Method of clearing retained for Modules II to VI

(2) Option 1 for clearing of Module $\dot{I}$.

(3) Option 2 for clearing of Module I.

(4) These methods of land clearing will generate a credit to the government. The dollar value of the credit cannot be evaluated at present... 
Carolina suggest that the base price could.vary from about $\$ 140$ per acre (low case) to $\$ 300$ per acre (high case). Land preparation costs for the PSBF could therefore vary from 70 percent to 150 percent of the cost estimated for the base case. The work roads which will be 25 feet wide, crowned and ditched, and drainage ditches will be installed at the same time that the land is prepared. The research and wood and equipment storage areas will be developed as part of the installation of the first module at each site. The cost of installation of the work roads and drainage ditches is estimated to be $\$ 0.50$ and $\$ 2.50$ per foot, respectively. Based on the data in Table II describing the site, the average cost of the work roads is $\$ 50$ per acre planted, or about 25 percent of the base cost of land preparation. The period required to prepare one module will be about thirty days (Appendix, Section 3). A period of two months was allowed for planning purposes to provide for various delays such as those resulting from inclement. weather and lead time to initiate the work. Data used in planning the land preparation work are presented in Table $\mathrm{V}$. Irrigation

The proposed layouts for the irrigation systems at the Jackson and Route 278 sites are shown on Figures 8 and 9 , respectively. Details are'presented in the Appendix, Section 4. Important features of the irrigation systems are:

- The systems are designed to meet the estimated peak water requirements of the SRP-PSBF at any time during a rotation. The capacity of each of the 3 wells at the Jackson site will be 1000-gallons per minute (GPM) and each at the. Route 278 site will have a capacity of 500 GPM. 
DATA BASE FOR SITE PREPARATION AND IMPROVEMENT AT THE PILOT SILVICULTURAL BIOMASS FARM

ITEM

$$
\begin{aligned}
& \text { Site preparation } \\
& \text { Cost: Base case } \\
& \text { Low case } \\
& \text { High case }
\end{aligned}
$$

Work road

$$
\text { Cost: }
$$

Drainage ditches

$$
\begin{aligned}
& \text { Cost: } \text { Rase rase } \\
& \text { Low case } \\
& \text { High case }
\end{aligned}
$$

Duration of site preparation

and improvement per module (2 sites)
UNITS

VALUE

\$/acre

\$/acre

\$/acre

200

140

300

\$ / foot

0.50

$\xi /$ foot

2.5

$\$ /$ foot

$\$ /$ foot

1.5

3.5

months 


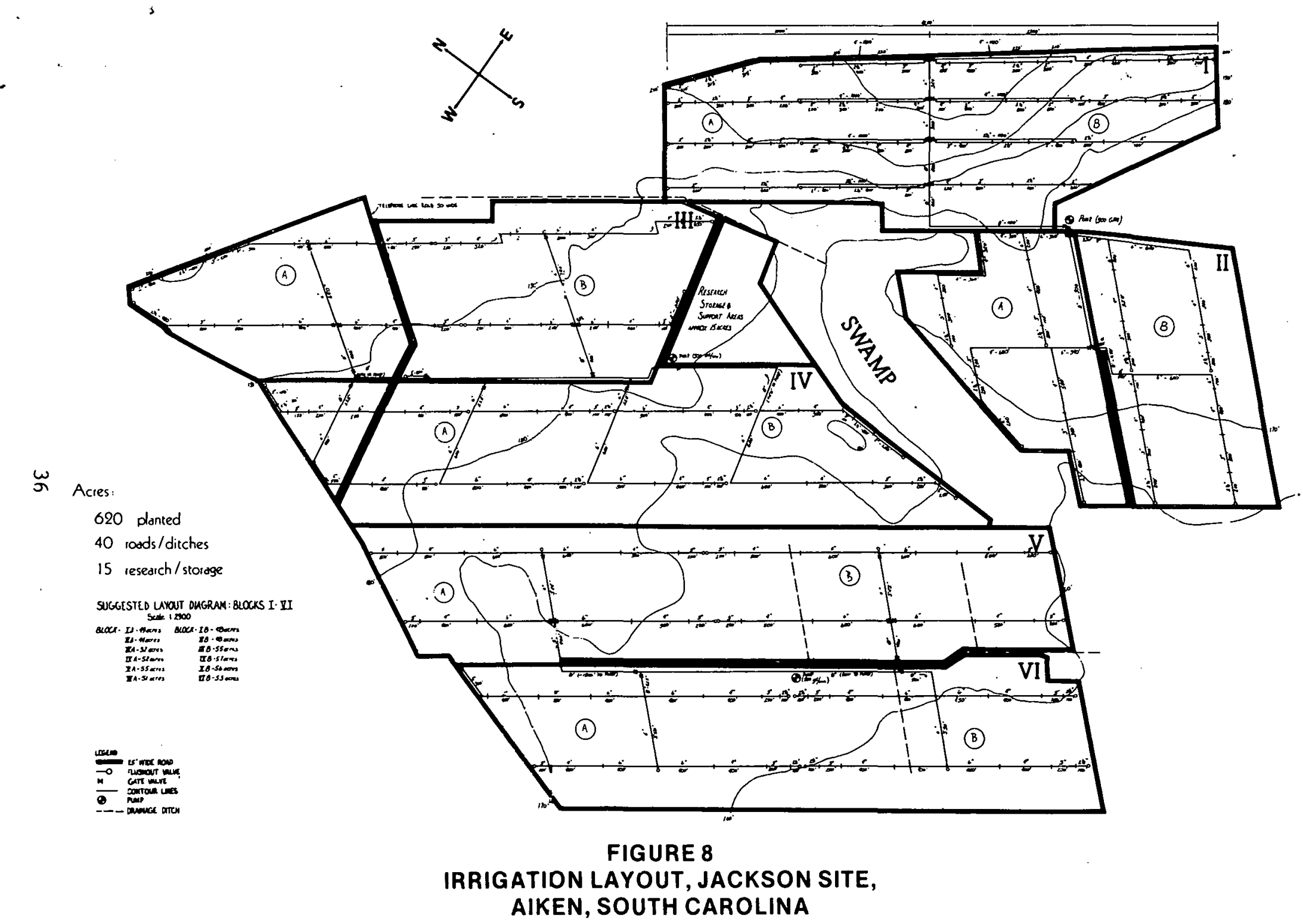




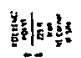

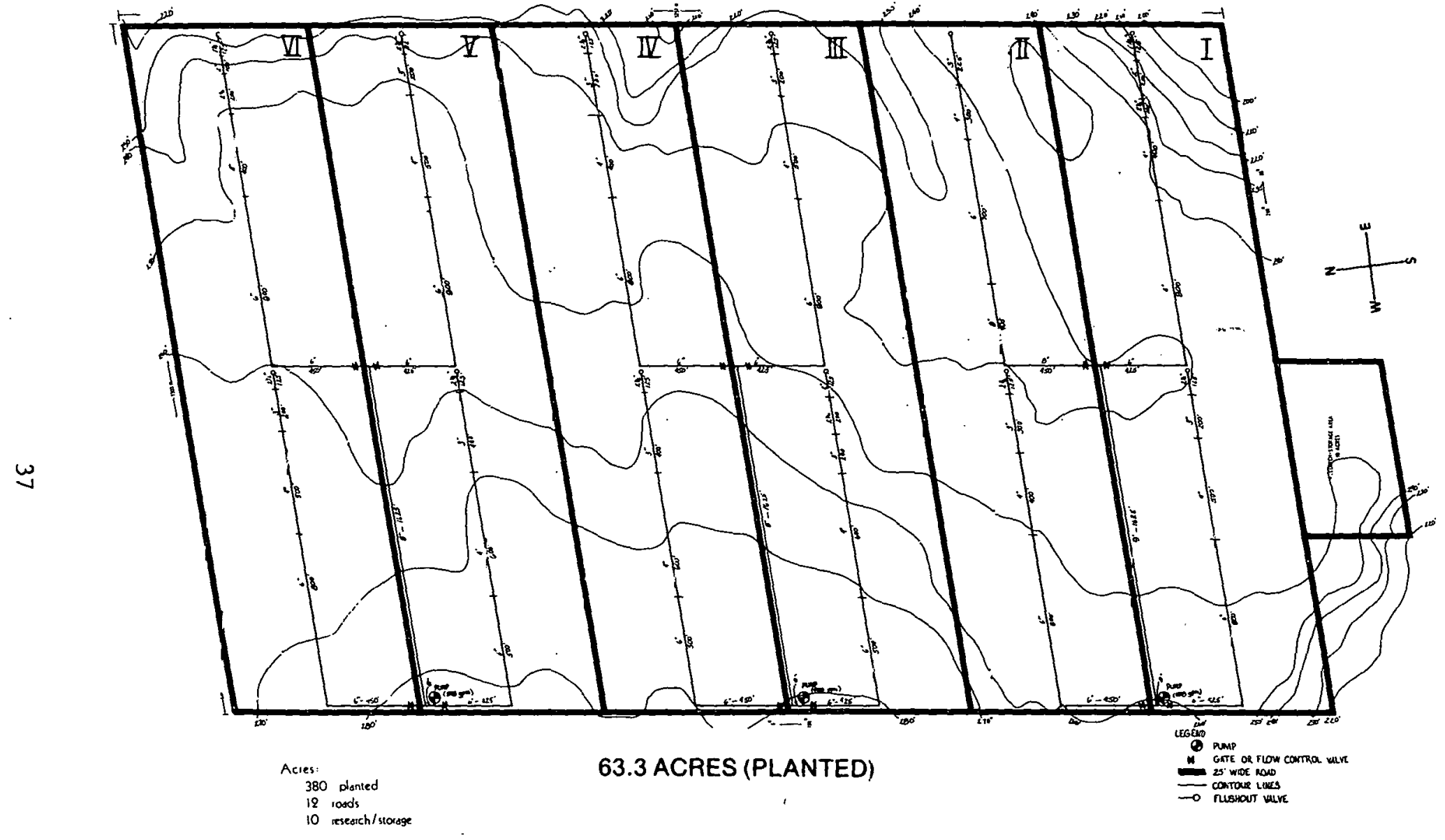

FIGURE 9

IRRIGATION LAYOUT, ROUTE 278 SITE, AIKEN, SOUTH CAROLINA 
- Two annual modules at each site will be irrigated with water from a single well.

- A complete daily irrigation cycle will include successive irrigation of the four half-modules served by one well. These are indicated as I-VI--A and B in Figures 8 and 9.

- Main and submain pipes buried at 3 feet and 18 inches, respectively, will supply water to plastic tubing running along each row of trees.

- Flow-regulating valves, flushout valves, a sand filter to eliminate grit and dirt from the well water, and pressure relief valves are integral components of the system.

- Three 5,000-gallon tanks with injection pumps will be used to meter liquid fertilizer into the irrigation water piped to each module. One of these tanks will be located near each we 11 .

- The well pump will be driven by a diesel engine to provide the greatest flexibility in controlling water flow.

- The irrigation system will be installed in two phases: 1) mains, submains and controls will be installed after site preparation. This can be accomplished in about one month. Materials should be ordered about three months prior to installation; 2) plastic tubing will be installed during the planting of secdlingo. This combined operaliua will require minor modifications of existing equipment. This is described in the Appendix, Section 6.

Features of the irrigation system are summarized in Table VI.

The average installation cost of the irrigation system, exclusive of wells and pumps, will be at about $\$ 530$ per acre. The replacement cost of plastic tubing after every harvest, i.e., every six years, will be about $\$ 230$ per acre.

Detailed characteristics, layout and costs for the components of the irrigation systems are presented in the Appendix, Section 6 . 
TABLE VI

CHARACTERISTICS OF THE IRRIGATION SYSTEM

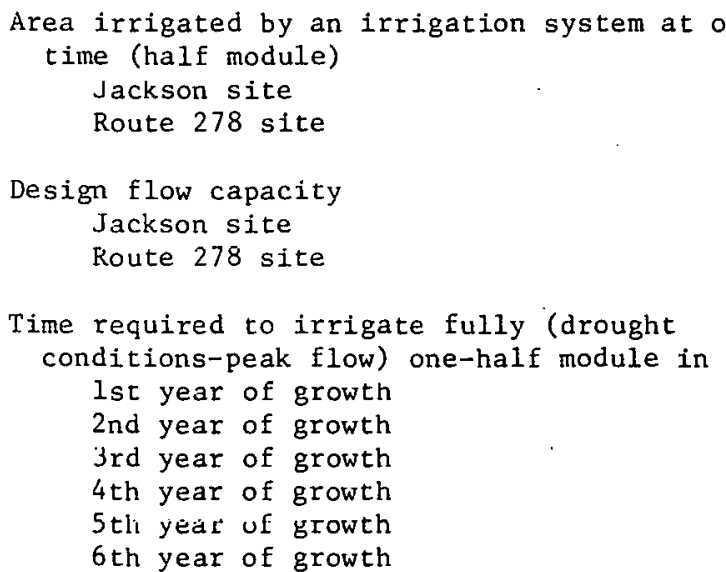

Time required to supply one acre-foot of water at peak flow

Jackson site

Route 278 site

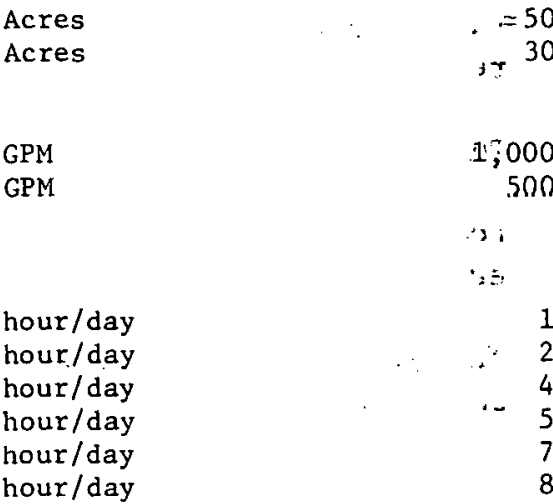

hours

hours

Spacing between drip irrigation pipes

Spacing hetween drip holes in plastic tubing

Working pressure of plastic tubes

Length of plastic tubing per acre planted

Average installation cost of irrigation system (excluding wells and pump)

Base case

Low case

ft.

ft.

2

psi

Et/acre $\quad 5,461$

Replacement cost of plastic tubing Base case Low case

Tanks for liquid fertilizer storage: Number per well or subsystem Capacity per tank

Duration of installation of the irrigation system for a module (including materials delivery)

$\$$ /acre $\quad 5.30$

$\$$ /acre $\quad 500$

S/acre 230

S/acre $\quad 200$

-

gallons $\quad 5,000$

tons of formulated $\quad=20$

months 4 


\section{Well Drilling and Pump Installation}

The proposed locations of the irrigation wells are shown in Figures 8 and 9 for the Jackson and Route 278 sites, respectively. Important characteristics of the wells include:

- Each well will supply irrigation water to two modules.

- Each well will consist of a 20 inch diameter concrete casing about 20 feet deep, followed by a 10 inch casing extending to a depth of about 250 feet. The final 100 to 200 feet of each well, extending to a depth of 350 to 450 feet, will be embedded in gravel and will include a screen.

- Each well will contain a submerged turbine driven by a vertical shaft connected to a diesel engine through a right angle coupling. This system was recommended by irrigation specialists in preference to an electrically driven pump (Appendix, Section 4). A one-month supply of diesel fuel will be stored at each well site.

- The planning schedule and cost estimates includé provisions for drilling a test well at each well location (Appendix, section 5). The total time required for installation of a well will be about six months. This includes ordering and delivery of required equipment.

Characteristics of the irrigation wells proposed for the SRP-PSBF are summarized in Table VII.

The estimated base case cost of a 1,000 GPM wel1 is $\$ 90,000$ and that of a 500 GPM well is $\$ 70,000$. On the basis of estimates made by well drillers, these installation costs might be reduced by about 5 percent under favorable conditions. On the other hand, unfavorable circumstances could require the driling of several test welis increasing costs by 15 to 20 percent. 
TABLE VII

CHARACTERISTICS OF THE WATER WELLS

ITEMS

UNITS

$\therefore$

Number of wells at each site

Capacity of the wells

Jackson site

Route 278 site

GPM

GPM

Ft.

Approxtmate depth of wells

Rating of diegel engine drive

Jackson site

Route 278 site

HP

HP

117

64

Fuel consumption for pumping (full capacity)

1,000 GPM well

500 GPM we11

Gallons diesel fuel/h

Gallons diesel fuel/h

$\$ /$ well

$\$ /$ wel1

0,000

$1,000 \mathrm{GPM}$ we11

500 GPM well

Months

6

Installation time

Cost of well, pump and drive- 
The average base case cost of the irrigation wells is $\$ 480$ per planted acre. The cost of the wells will thus increase the base case cost of the complete irrigation system to about $\$ 1,000$ per planted acre. ,

\section{Planting}

Year-old bare-root seedlings will be purchased from a state nursery and ,planted during the month of February during six consecutive years beginning in 1981. The following are important considerations related to seedlings:

- The South Carolina State Commission of Forestry, Columbia, South Carolina, will supply sycamore, European alder and - slash pine seedlings as required.

- The first order for the seedlings must be placed by September 1, 1979 to meet the February 1981 planting deadline.

- Seedlings will be lifted, packed and stored at the nursery for pick-up beginning January, 1981. Cost and shipping data for seedlings are presented in Appendix A- 6 .

Two-row commercial planters will be used for planting. Characteristics of this equipment are summarized in Appendix A-6. It is suggested that three planters be purchased for the PSBF. At the expected planting rate of 7,000 seedlings per day, this equipment would be used to plant one module at each site in about one month. It was suggested that irrigation tubing should be installed at the time of planting (Appendix, Section 4). This combined operation could be accomplished by modifying currently available equipment and would require only one tractor. Planting data are summarized in 
Table VIII and supporting data and references are provided in the Appendix, Section 6 .

The estimated planting cost of $\$ 55$ per acre is somewhat higher than the $\$ 30$ per acre required to stock conventional forest stands in the region. The latter cost, however, is for plantings of 600 trees per acre (about $8^{\prime} \times 10^{\prime}$ ) rather than 2700 trees per acre and equipment can, therefore, move faster. The estimated planting "cost of $\$ 55$ per acre assumes that a team of three laborers will operate each planter.

\section{Storage and Service Areas}

Each site will include a small research area for field experimentation.. It is proposed that the following support equipment and buildings be provided:

- Office and research space--a mobile home converted to office and laboratory use;

- Storage--prefabricated metal buildings for storage of equipment and supplies;

- Laboratory equipment for research and tests; and

- Scrvices including electric power, septic field, gasoline tank, etc.

A list of proposed equipment and services is provided in Table IX and cost and technical data are summarized in the Appendix, Section 7. Biomass Farm Operation

The major activities of a biomass farm include cultivation for weed control, irrigation, fertilization, harvesting, maintenance, 
TABLE VIII

DATA BASE FOR PLANTING

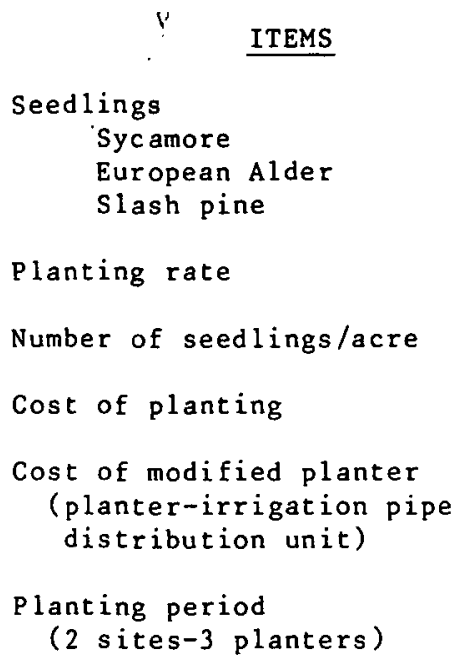

Seed 1 ings

Syc amore

European Alder

Slash pine

Planting rate

Number of seedlings/acre

Cost of planting

Cost of modified planter

(planter-irrigation pipe distribution unit)

Planting period

(2 sites-3 planters)

UNITS

VALUE

$\$ 1 / 1,000$

$\$ 1 / 1,000$

30

$\$ 1 / 1,000$

30

Seed lings/day

7,000

Seed 1 ings/acre

2,725

\$lacre

\$/unit

10,000

Month 
TABLE IX

EQUIPMENT AND SERVICES FOR THE RESEARCH AND STORAGE AREAS

\section{ITEMS}

Office and laboratory space

Area: Jackson site

Route 278 site

Cost (installed)

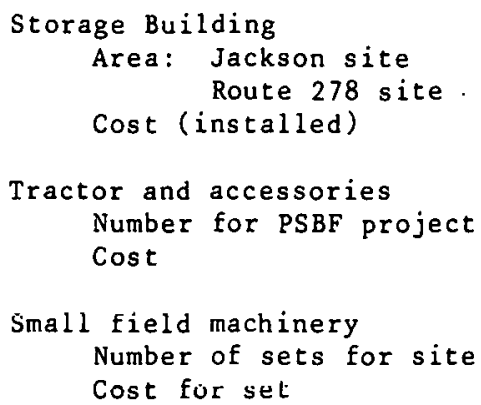

Basic laboratory equipment (2 sites)

office equipment ( 2 sites)

Services

(septic fields, power lines,

phone lines, gasoline tanks,...

2 sites)

Vehicles

( 4 wheel drive $1 \mathrm{~T}$ trucks)

Number for PSBF

Cost
UNITS

VALUE

Ft ${ }^{2}$

$\mathrm{Fr} \mathrm{r}^{2}$

$\$ / F t^{2}$

$F t^{2}$

$\mathrm{Ft}{ }^{2}$

$s / \mathrm{F}+2$

l, 500

800

ir. 20

3,000

2,000

$9: 50$

;es

\$/Unit

1

20,000

S/set

10,000

$\$$

20,000

$\$$

10,000

$\$$

25,000

$\$ /$ Unit $\quad 8,000$ 
record keeping and management. The schedule for field operations, summarized in Figure 10 is discussed below.

\section{Cultivation}

Biomass farms will require cultivation until trees are large enough so that competition by weeds will not inhibit their growth. The frequency of cultivation will depend upon factors such as site productivity and the age at which seedlings are planted. Data collected during short rotation pulpwood operations suggest the following weed control schedule:

- Cultivation every three weeks or seven times between April and early September during the first year of a rotation,

- Cultivation every four weeks, or five times during the second year of a rotation.

The cost of each cultivation treatment will be approximately $\$ 10$ per acre. The annual cost will be $\$ 70$ per acre for the first year and $\$ 50$ per acre for tho oocond year. Actual sosts of rultivation may vary from $\$ 9$ per acre per treatment to $\$ 12$ per acre per treatment because of terrain differences and module layout. The average cost of cultivation may vary from $\$ 110$ to $\$ 145$ per acre for each six year rotation.

Particularly extensive weed growth could result in a need for ten cultivation treatments per acre (every two weeks) the first year, six per acre (every three to four weeks) the second year, and once the fourth year. The cost of this cultivation program would be 


\begin{tabular}{|c|c|c|c|c|c|c|c|c|c|c|c|c|c|c|c|c|c|c|c|c|c|c|c|c|}
\hline MODULES & OPERATIONS & $P_{1981}$ & 1982 & 1983 & 1984 & 1985 & 1986 & 1987 & 1988 & 1989 & 1990 & 1991 & 1992 & $1 \leq 93$ & 1994 & 1995 & 1996 & 5. 1997 & 1998 & 1999 & 2000 & 2001 & 2002 & 2003 \\
\hline I & $\begin{array}{l}\text { Cultivation } \\
\text { Irrigation/ } \\
\text { Fe:tilization } \\
\text { Harjesting } \\
\text { Planting }\end{array}$ & . & . & \begin{tabular}{|c|}
+ \\
.
\end{tabular} & - & - & : & - & $\begin{array}{l}\cdot \\
.\end{array}$ & + & $\bullet$ & $\cdot \bullet$ & $\dot{0}$ & $\begin{array}{l}\cdot \\
\cdot \\
\mathbf{x}\end{array}$ & $\cdot$ & + & - & • & $\dot{0}$ & $\begin{array}{l}\cdot \\
\cdot \\
\mathrm{x}\end{array}$ & $\cdot$ & + & - & - \\
\hline II & $\begin{array}{l}\text { Culifvation } \\
\text { Irrjgation/ } \\
\text { Fertilization } \\
\text { Harresting } \\
\text { Planting }\end{array}$ & & • & $\begin{array}{l}\cdot \\
\bullet\end{array}$ & $\begin{array}{l}+ \\
.\end{array}$ & - & - & $\bullet$ & $\begin{array}{l}\cdot \\
\cdot \\
\mathrm{x}\end{array}$ & . & + & - & $\cdot$ & $\dot{0}$ & $\begin{array}{l}\cdot \\
\cdot \\
\mathrm{x}\end{array}$ & $\cdot$ & + & - & - & $\dot{0}$ & $\begin{array}{l}\cdot \\
\cdot \\
\mathrm{x}\end{array}$ & • & + & - \\
\hline III & $\begin{array}{l}\text { Cultivation } \\
\text { Irrigationi } \\
\text { Fertilization } \\
\text { Harvestlng }\end{array}$ & & & $\begin{array}{l}\cdot \\
.\end{array}$ & •. & $\begin{array}{l}+ \\
\bullet\end{array}$ & • & - & $:$ & $\begin{array}{l}. \\
.\end{array}$ & $\begin{array}{l}. \\
.\end{array}$ & $\begin{array}{l}+ \\
\cdot\end{array}$ & - & - & - & . & $\cdot$ & + & - & - & - & $\begin{array}{l}\dot{ } \\
0\end{array}$ & $\cdot$ & $\begin{array}{l}+ \\
.\end{array}$ \\
\hline IV & $\begin{array}{l}\text { Cultivation } \\
\text { Irrigation/ } \\
\text { Fertilization } \\
\text { Harvesting }\end{array}$ & & & & • & • & + & - & - & $:$ & • & $\begin{array}{l}\cdot \\
.\end{array}$ & + & - & - & $i$ & . & $\cdot \vec{\cdot}$ & + & - & - & - & - & $\begin{array}{l}\cdot \\
\cdot\end{array}$ \\
\hline $\mathrm{v}$ & $\begin{array}{l}\text { Cultivation } \\
\text { Irribation/ } \\
\text { Fertilization } \\
\text {.Harvesting }\end{array}$ & & & & & • & • & + & - & - & - & - & . & $\begin{array}{l}\div \\
.\end{array}$ & - & - & - & $\cdot \mid$ & . & + & $\cdot$ & - & - & • \\
\hline VI & $\begin{array}{l}\text { Cultivation } \\
\text { Irrigation/ } \\
\text { Fertilization } \\
\text { Harvesting }\end{array}$ & & & & & & • & . & $\begin{array}{l}+ \\
.\end{array}$ & - &. & $\vdots$ & $\begin{array}{l}. \\
. \bullet\end{array}$ & . & + & - & - & : & - & . & + & - & - & $:$ \\
\hline
\end{tabular}

Key: - Operation occurring during the year indicated.

o - Coppice än rvests.

$X$ - Replancling of Slash Ptne (one-fourth of annual module at Jackson and Rourte 278 s:tes).

+ - Only lncluded for "higi level" cultivation 1.e., cultivation during the three firm years.

'Calendar years. 
2170 per acre over a six year rotation. This represents an increase of about 40 percent over the base case.

If the growth of weeds is less than anticipated, cultivation may be required five times (every four weeks) during the first year, and three times (every six weeks) during the second year. The cost would be $\$ 80$ per acre over a six year rotation, i.e., about 35 percent less than the base case.

Technical and cost data for cultivation are summarized in the Appendix, Section 3, and Table X summarizes the features of the base case cultivation program.

With the exception of the year 1981 when only one module will be planted, about 2,000 acres (Table XI) must be cultivated annually at an anticipated average cost of about $\$ 20,000$. Actual annual costs for cultivation may be as 1 ow as $\$ 13,000$ or as high as $\$ 28,000$.

Fertilization.

It is generally recognized that fertilization will be necessary on short rotation energy farms in order to:

- Achieve desired productivity levels;

- Ensure economic success; and

- Replace the soil nutrients used.

Fertilization Requirements - Annual fertilization requirements have been estimated by two independent methods. In the first method, the content of nitrogen (N), phosphorus (P) and potassium (K) from 


\section{TABLE X}

DATA BASE FOR THE CULTIVATION PROGRAM

\section{ITEMS}

Number of cultivations per growing season Base case:

lst year

2nd year

High rase:

lst year

2nd year

3 rd year

Low case;

lst year

2nd year

Cost of one cultivation (base case)

Expected range of cultivation cost

\section{h}

UNITS

VALUE

\section{n}


TÁBLE XI $\because \underset{\vdots}{ }$

ACREAGE TO BE OULTIVATED YEARLX DURING THE LIFETIME OF THE PILOT SILVICULTURAL BIOMASS FARM

(BASE CASE)

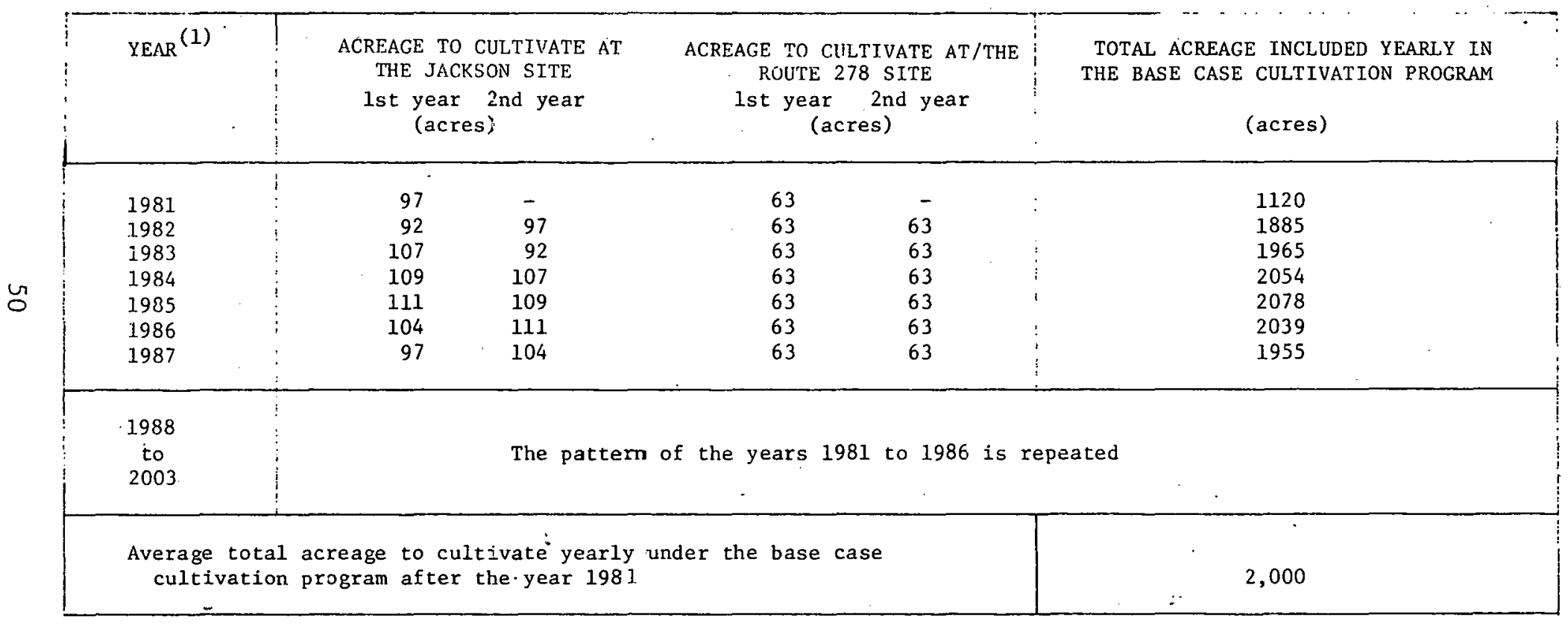

(1) Calendar year. 
hardwood species was analyzed. 1 The data were used to determine the amount of fertilizer needed per acre-year at various stages of growth during a six-year rotation for a base case productivity of 8 DTE per acre-year. The suggested yearly application rates were then determined assuming a 60 percent recovery factor. The results of this analysis are shown in Table XII.

The second method of estimating nutrient requirements was based on current agricultural practice on pasture land in Georgia. About 500 to 800 pnunds of 6-12-12. agricultural fortiliger arc applied annually to maintain productivities of about three tons of hay per acre-year. For an annual productivity of 8 DTE per acre-year, agricultural practice would suggest an average application of 104 pounds of nitrogen, 208 pounds of phosphorus as $\mathrm{P}_{2} \mathrm{O}_{5}$, and 208 pounds of potassium as $\mathrm{K}_{2} \mathrm{O}$. When these rates are compared with the average rates shown in Table XII, it is apparent that the two methods of evaluation agree well for nitrogen, fairly well for potassium and not as well for phosphorus.

Fertilizer application rates of 150 pounds of nitrogen and 80 pounds of phosphorous per acre-year for productivities of about 5.5 DTE per acre-year have been used by the International Paper Company. 2 These application rates exceed nutrient demand and IInman, R.E., D.J.Salo, "Silvicultural Biomass Farms, Vol. IV, Site-Specific Production Studies and Cost Analysis," MTR 7347, MITRE/Metrek, McLean, VA, 1977

2 John Nugent, International Paper Company, Natchez, MS, personal communication, June 1978. 
TABLE XII

APPLICATION RATES OF NITROGEN, PHOSPHORUS AND POTASSIUM

FERTILIZERS REQUIRED TO REPLACE MINED

NUTRIENTS AT THE PILOT SILVICULTURAL BIOMASS FARM

BASE CASE: PRODUCTIVITY $=8 \mathrm{DTE} / \mathrm{ACRE}-\mathrm{YEAR}$

Application Rate (lbs/acre-year)

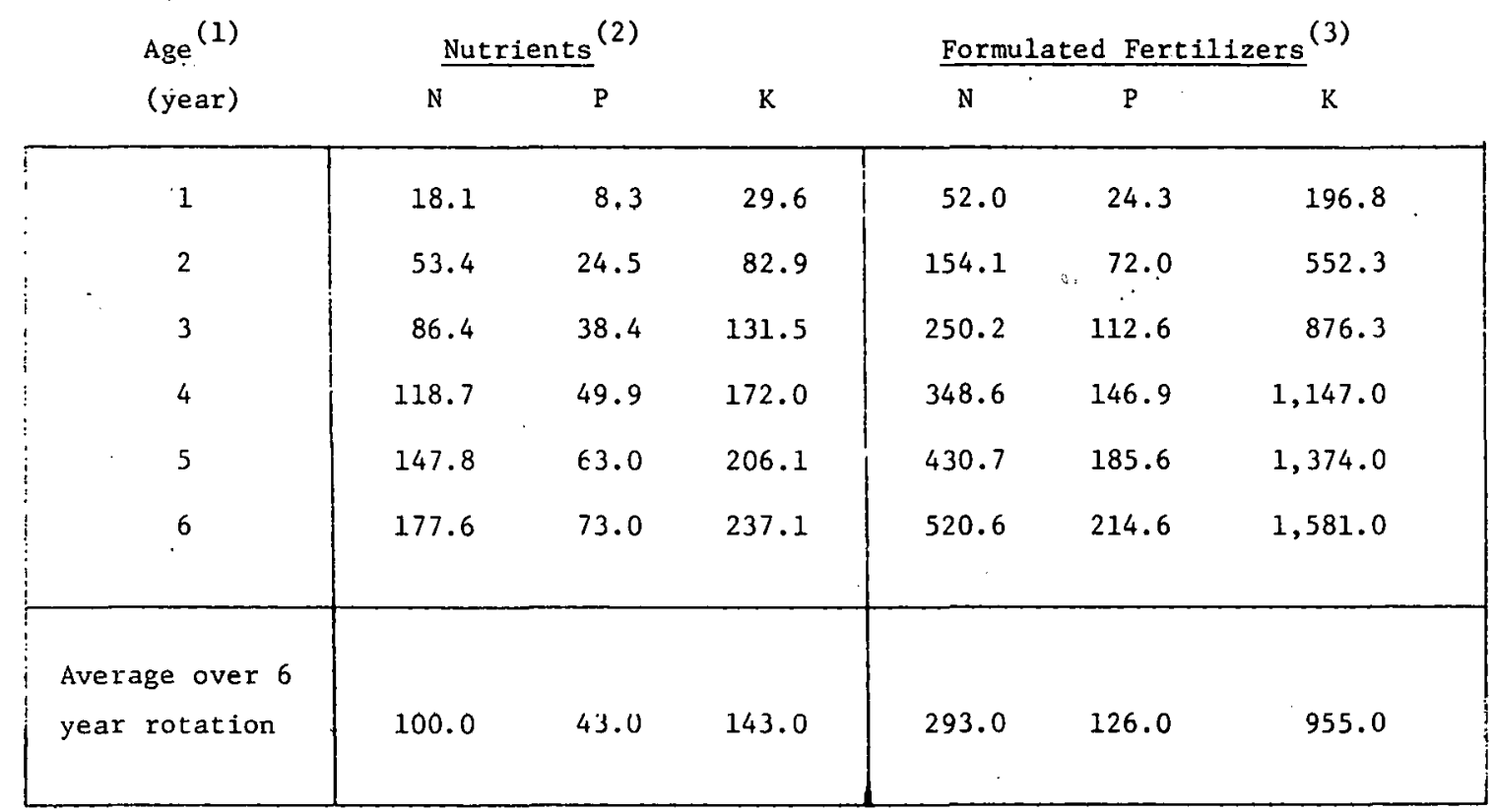

(1) Age since planting

(2) $\mathrm{P}$ as $\mathrm{P}_{2} \mathrm{O}_{5}, \mathrm{~K}$ as $\mathrm{K}_{2} \mathrm{O}$; includes 60 percent recovery factor.

(3) Liquid fertilizers:

$\mathrm{N}$ : Urea-ammonium nitrate solution, $30 \% \mathrm{~N}$

P: Urea-super phosphate solution, $10 \% \mathrm{~N}, 34 \% \mathrm{P}_{2}{ }_{5}$

K: Potassium oxide solution, $15 \% \mathrm{~K}_{2} 0$ 
correspond to 218 pounds of nitrogen and 116 pounds of phosphorous per acre-year for a productivity of 8 DTE per acre-year.

Application rates of 100 pounds of nitrogen per acre-year are used on experimental plots having productivities of about 8 DTE per acre-year in Wisconsin.1 Nitrogen application rates of 80 to 100 pounds per acre-year are also generally accepted by the Environmental Protection Agency (EPA) as design rates for wastewater application to forest land. 2

The application rates suggested in Table XII reflect the considerations discussed above, but it should be emphasized that considerable uncertainty exists regarding nutrient levels required to maintain given productivities. It is questionable, however, whether nutrient levels lower than those suggested in Table XII will be sufficient to maintain base case productivity. Foliar and soil N, P, K and micronutrient concentrations should be monitored to help assure that proper nutrient levels are maintained. Such information would also be of value in developing fertilization strategies for commercial biomass farms.

Fertilization Program - Liquid fertilizer will be applied annually during the growing season through the drip irrigation system. Liquid fertilizers will include:

- Urea-ammonium nitrate solution ( 30 percent $N$ ), TJ, Zavitkovski, USDA/Forest Service, Rhinelander, WI, personal communication, June 1978.

2Environmental Protection Agency, Land Treatment of Waste Waters, Technology Transfer, 1975. 
- Urea-superphosphate solution (10 percent $\mathrm{N}, 34$ percent $\mathrm{P}_{2} \mathrm{O}_{5}$ ), and

- Potassium oxide solution (15 percent $\mathrm{K}_{2} \mathrm{O}$ ).

Fertilizer solutions will be stored in six 5,000 gallon tanks, one of which will be located near each of the six wells on the PSBF. The fertilizers will be added to the irrigation stream as required.

The estimated annual application rates for formulated fertilizers are presented in Table XIII. These data were used to estimate the costs associated with the fertilization program.

After all six modules at a site are planted, formulated fertilizers will be applied at an average annual rate of about 145 tons $\mathrm{N}$, 65 tons $P$ and 480 tons $K$. This will cost about $\$ 47,000$ dollars per year at 1978 prices, or about $\$ 47$ per acre-year. 1

Annual Fertilization Schedule - The fertile soils at the Jackson site should retain nutrients administered during fertilization treatments. Jackson site modules, therefore, will be fertilized four times during each growing season. However, this treatment schedule may not correspond to that required for water application and additional irrigations may be necessary to apply nutrients. For each application, the nutrients required will be metered into the irrigation system which will operate at full capacity for a period of six hours. This treatment period will be followed by two hours of

\footnotetext{
Turrent costs of formulated fertilizers delivered f.o.b. to Aiken, SC are: urea ( 30 percent $N$ ) - $\$ 90 /$ ton; urea-superphosphate solution ( 10 percent $\mathrm{N} ; 34$ percent $\mathrm{P}_{2} \mathrm{O}_{5}$ ) - $\$ 155 /$ ton; $\mathrm{K}_{2} \mathrm{O}$ solution (15 percent $\mathrm{K}_{2} \mathrm{O}$ ) - $\$ 50 /$ ton--see Appendix for data.
} 
TABLE XIII

ANNUAL APPLICATION RATES OF NUTRIENTS BY MODULES OVER THE LIFETIME OF THE PILOT SLLVICULTURAL BIOMASS FARM-BASE CASE

(Tons of formulated fertilizers/year) ${ }^{(1)}$

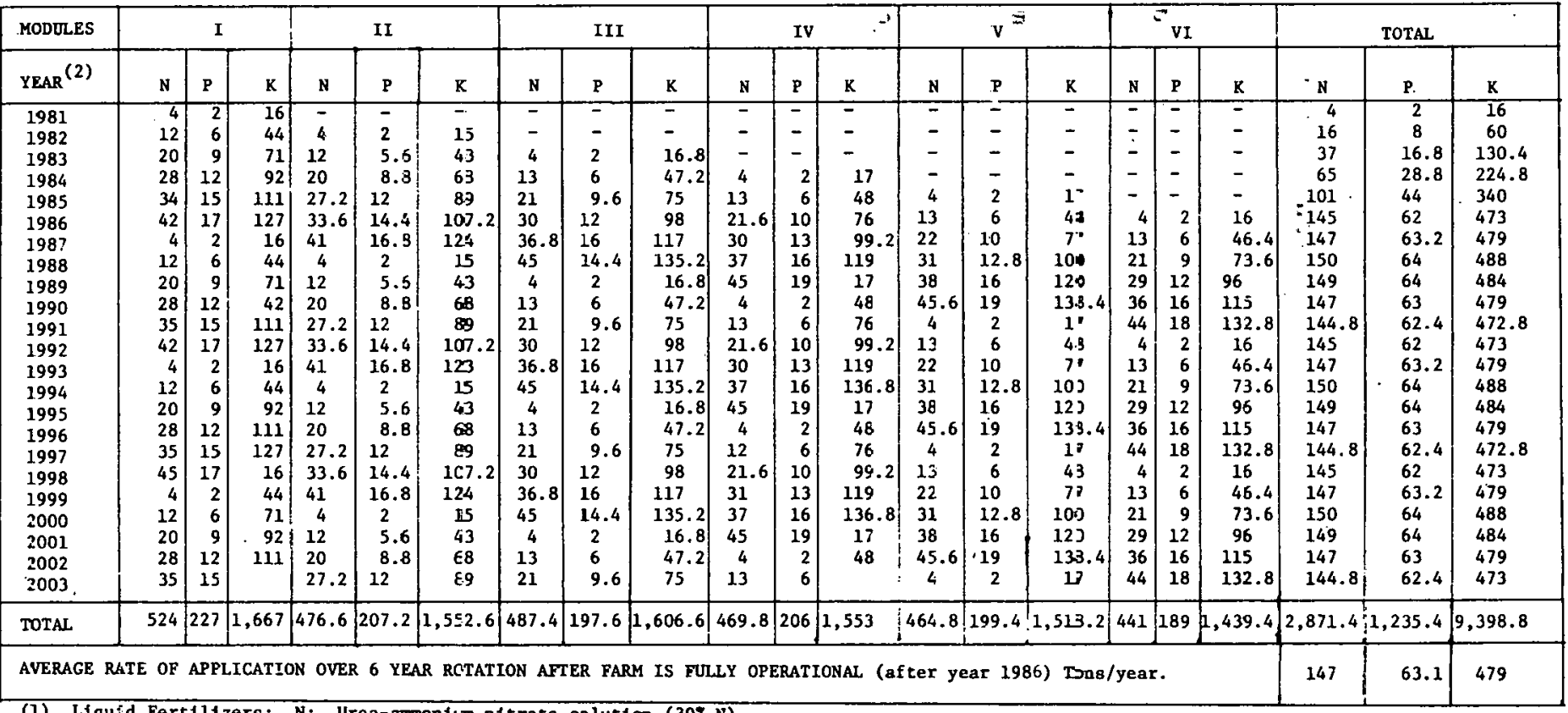

$\mathrm{P}$ : Urea-super-phosphate solution (10z N, $\left.34 \mathrm{Z} \mathrm{P}_{2} \mathrm{O}_{5}\right)$

Amounte determined on the basis of retes of application of Table XII.

Micro cutrients to be added as chelates as needed.

Note: 1 ton of forwalated 11 quid ferthlizer 18 about 250 gallons.

Amouncs are tocal for modules at botb the Jackean and 250

(2) Calender years. 
irrigation without fertilizer to flush the system and to avoid clogging, of drip holes by crystalized salts and algae. The total time required for fertilization at the Jackson site will be about 400 hours. 1

Soils at the Route 278 site are sandy and will not retain water or nutrients. It is proposed, therefore, that two acre-feet of water be used to irrigate the site each year. This recommendation is based on results obtained during the analysis of a hypothetical site in Metrek's system study of silvicultural biomass farms. 2 It will require the irrigation of each module every other day during the growing season. The application of nutrients can be accommodated into this irrigation schedule, and additional water will not be required. for fertilization. The annual fertilizer requirement can be met with equal biweekly nutrient applications during the growing season. This schedule will help to assure nutrient sufficiency in the sandy soils which are subject to leaching.

\section{Irrigation Program}

It was estimated that one acre-foot of irrigation water per year will be required at the Jackson site to compensate for water deficits during the growing season. 3 The 1000 GPM irrigation system at that

T8 hrs per treatment times 4 treatments per year times 12 halfmodules per site.

2 Inman, R.E. and D.J. Salo, "Silvicultural Biomass Farms, Site Specific Production Studies and Cost Analyses," Vol. IV, MTR 7347, MITRE/Metrek, McLean, VA, 1977.

3 Inman, R.E. and D.J. Salo, "Identification of sites for a Pilot Silvicultural Biomass Farm at the Savannah River Plant." WP 12676, MITRE/Metrek, October 1977. 
site will operate approximately 3000 hours per year to deliver the water required during these dry periods. This corresponds to the irrigation of each module once each week during the growing season, but actual irrigation treatments will occur on an irregular basis as necessary.

It is anticipated that an additional 400 hours of full capacity pumping will be required at the Jackson site to meet water requirements during droughty years (Table VI). The annual cost of irrigation at the Jackson site will be $\$ 12,000$ during normal years, and $\$ 16,000$ during droughty years. As previously.indicated, it will be necessary to irrigate the Route 278 site at an annual rate of two acre-feet. The $500 \mathrm{GPM}$ irrigation system at that site will operate approximately 3000 hours per year to deliver the required water. This corresponds to irrigating each module every other day during the growing season. The annual cost of this irrigation schedule at the Route 278 site will be about $\$ 17,000$. It is likely that one person will be able to operate and maintain the irrigation systems at both sites. Data relevant to irrigation operations at the PSBF are summarized in Table XIV.

\section{Harvesting}

The PSBF will serve as a test site to evaluate harvesting equipment specifically designed for silvicultural biomass farms. This machinery is currently being developed, so for present planning purposes the costs of conventional harvesting operations have been used. Data are summarized in Table XV. 
DATA BASE FOR THE IRRIGATION PROGRAM

ITEMS

UNITS

Jackson site:

Base case:

Irrigation needs.

Cost

High case:

Irrigation needs

Cost

Route 278:

Irrigation needs

Cost
Acre-foot/acre-year

$\$ /$ acre-year (3)

$1.2^{(1)}$

23

Acre-foot/acre-year

\$/acre-year (3)

$1.5^{(2)}$

27

Acre-foot/acre-year

\$/acre-year (3)

VALUE

(1) Includes supplementary water for application of fertilizers four times per year.

(2)

Includes supplementary water for application of fertilizers four times per year, irrigation during 15 days of drought and base case irrigation of 1 acre-foot.

(3) Based on fuel consumption and pump performance shown in Table VII. 
ITEMS

Harvesting period

Harvesting capacity

Harvester fuel consumption

Wagon capacity

Wagon cost

Number of wagons for the TSBF

Cost of harvesting

Base case (1): fuel (2)

personnel (3)

total

Low case (4): total

High case(5): total
UNITS

VALUE

Nov. 15 to

March 1 .

DTE/hour

10

Ga1. diesel

fuel/hour

DTE

\$/unit

7,500

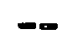

2

$\$$ /acre

43

$\$$ /acre

63

\$/acre

106

$\$ /$ acre

66

-\$/acre

(1) Productivity: 8 DTE/acre-year

(2) Include fuel for dump wagon

(3) Temporary personnel: one heavy equipment operator and one laborer

(4) Productivity: $5 \mathrm{DTE} /$ acre-year

${ }^{(5)}$ Productivity: $10 \mathrm{DTE} /$ acre-year 
Harvesting will be performed during, the winter dormant season. Trees will be felled, bunched, skidded and chipped by different machines if conventional practice is employed. If prototype harvesters are used, the actual harvest sequence will depend upon the characteristics of the equipment. One possibility is that a mobile feller-chipper will fill a trailing wagon which will be pulled to the chip storage area by a tractor when it is full. It may be necessary to harvest on a two-shift basis for part of the harvest period, depending upon equipment used, weather and other variables. This possibility must be considered in planning the details of the harvest operations .

\section{Maintenance}

The following maintenance operations are routinely planned for the PSBF :

- Hork road improvement after each harvest or every six years. This will include crowning and ditching. The work will be subcontracted;

- Replacement of irrigation tubing after each harvest. This work will be subcontracted; and

- General maintenance of buildings and equipment (painting, minor repairs, vehicle lubrication, etc.) Small jobs will be done by the permanent staff of the PSBF while major repairs will be subcontracted.

\section{Personne1}

The following personnel will be required to operate the PSBF:

- Supervisor: responsible for day-to-day management of the project and coordination with outside contractors, SRP and DOE ; 
- One Tractor Operator: cultivation during the growing season, harvesting during the dormant season, maintenance;

- One Farm Laborer: irrigation/fertilization system operation and maintenance during the growing season, biomass storage and equipment maintenance during the winter; and

- One Clerk-Bookkeeper.

These workers will be employed on a full-time basis and will be assisted by part-time laborers as needed. Part-time employees will be needed to perform tasks such as replanting 81 ash pine stands and clearing drainage ditches. It is estimated that about 60 man-days of part-time labor will be required annually.

In addition to field personnel, it will be necessary for the contractor to provide one man-year of engineering and one-half manyear of technical support annually. 
THIS PAGE

\section{WAS INTENTIONALLY LEFT BLANK}


IMPLEMENTATION PLAN FOR THE PILOT SILVICULTURAL BIOMASS FARM

Following the conceptual design for the Pilot Silvicultural Biomass Farm presented in the previous section, the first annual module will be planted in February, 1981 and will be followed by planting of subsequent modules at one year intervals until 1986. Careful planning and coordination of the operations required prior to planting will be needed if the first and subsequent planting dates are to be met. Failure to meet the February, 1981 planting deadline will delay establishment of each pair of modules by one year. Installation Plan for the Pilot Silvicultural Biomass Farm

The various operations described in the design and planning schedule are different for Modules I than for other modules and therefore are discussed separately.

Planning for the Installation of the First Modules

A preliminary assessment of the time available until the first seedlings will be planted in February, 1981, showed that land clearing by a timber sale, the preferred method, may be difficult to schedule.

Two alternative options for the installation of the first modules, therefore, have been considered. Both options assume that installation activities will begin in early August, 1979.

Option 1 - The first modules at each site could be cleared through a salvage wood sale. This procedure is less desirable than a tiuber sale from an economic point of view but can be concluded in a much shorter period of time. 
Three dates are critical if this option is selected:

- September 1, 1979 - Year 1 seedlings would be ordered;

- December 1, 1979 - Land clearing through salvage sale would be initiated;

- February 1; 1981 - Year 1 seedlings would be planted.

As indicated here, several operations may have to begin before a prime contractor for the SRP-PSBF can be selected through a regular RFP-bid-contract cycle. It is suggested therefore that, if needed, an acting contractor be selected to initiate and manage the program until the permanent contractor takes over. The acting contractor would be responsible for the on-time completion of tasks represented by paths 1 to 14 and 7 to 10 in Figure 11 and Table XVI. This would ensure that the first modules will be planted during early 1981 .

Other paths are more flexible as provisions for delays have been included in the schedules.

Option 2 - The first modules at oash oitc could be cleared w1thout recovery of the wood. This method of clearing is the fastest, but does not bring any cash to the Treasury.

The schedule of operations is shown on Figure 12 and the operations are described in Table XVII.

Four dates are critical if this option is chosen:

- September 1, 1979 - Year 1 seedlings would be ordered;

- March 1, 1980 - Prime contractor would begin work;

- April 1, 1980 - Land-clearing would begin;

- February 1, 1981 - Year 1 seedlings would be planted. 
In this option, all work except the ordering of seedlings would be performed after contractor selection through a regular RFP-bidcontract cycle. The contractor therefore would have complete responsibility for the project from its initiation.

The paths 1 to 14 and 7 to 10 in Figure 12 represent the tasks which must be completed on time if an early 1981 planting deadline is to be met. Other paths are less critical because provisions have been made in the schedule for delays due to bad weather, contract negotiations with subcontractors, etc. Installation of Modulco II, TV, VI

The installation of modules two, four and six will not include building installation, vehicle and planting equipment purchases or well drilling. Wells installed on modules one, three and five will supply irrigation water to all six modules at each site. Land clearing will be accomplished through timber sales.

The schedule of operations and the operations themselves, are described in Figure 13 and Table XVIII.

For a planting deadline of February 1 , Year $\mathrm{N}(\mathrm{N}=1982,1984$ or 1986), the following dates are critical:

- January 1, Year $\mathrm{N}$ minus 2 - timber sale initiated. In the case of module 2, this deadline is January 1, 1980. The timber sale for module 2 will be initiated by an acting contractor (option 1) or by the permanent contractor (option 2);

- September 1, Year $N$ minus 2, seedlings ordered;

- February 1, Year N, seedlings planted.

The acquisition of seedlings on schedule (path 3-7) is critical to the installation of modules II, IV and VI. There is some flexibility 


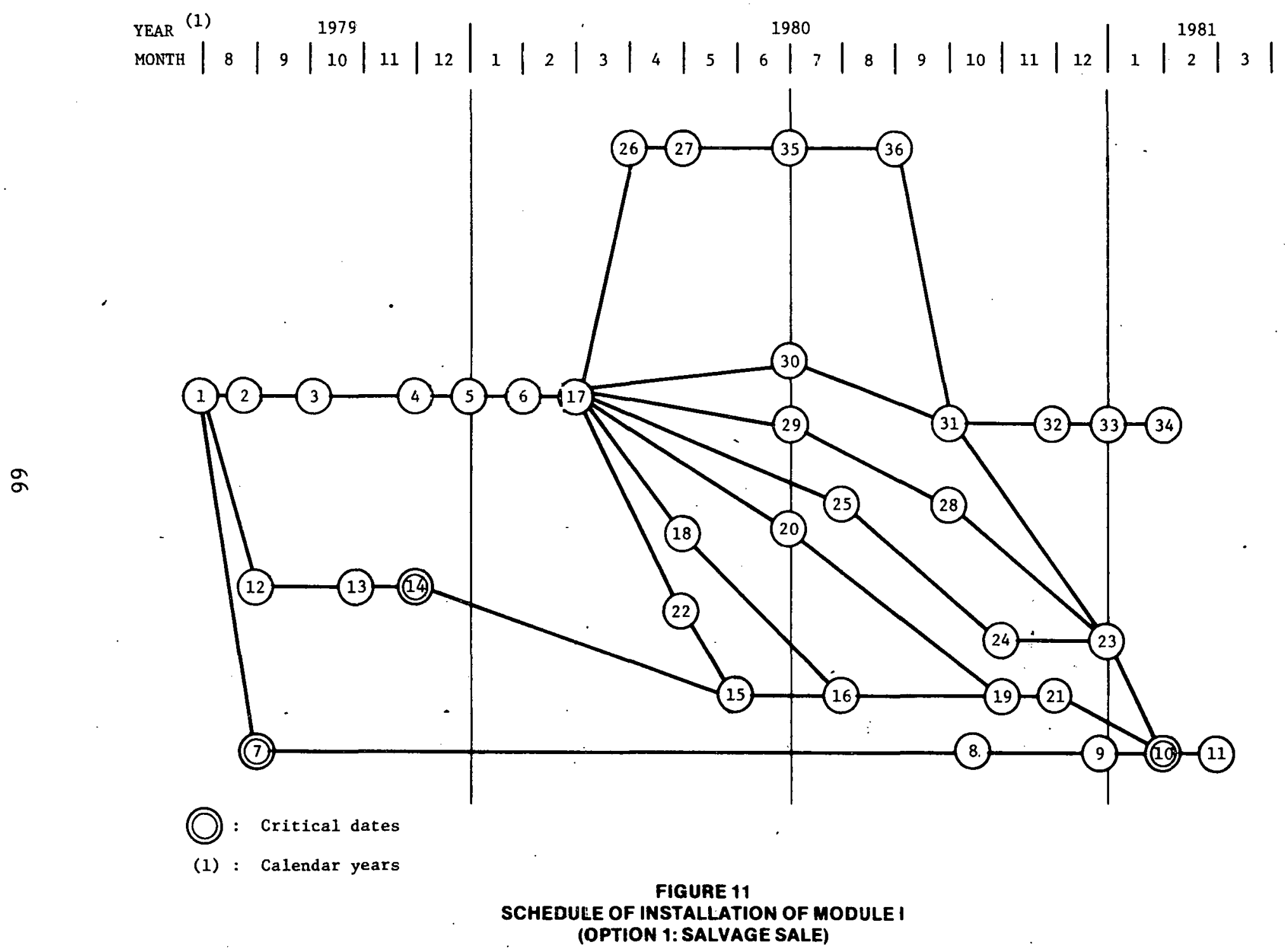


TABLE XVI

OPERATIONS FOR SCHEDULE OF INSTALLATION OF FIRST MODULES

(Opetion 1 - Salvage Sale Approach)

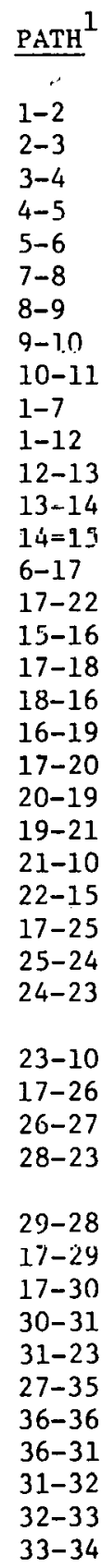

\section{OPERATIONS}

Prepare RFP

Issue RFP

Receive proposals

Select contractor

Finalize contract

Seedling production (nursery)

Seedling storage (nursery)

Seedling delivery

Planting and irrigation pipes in place

Order seedlings

Sclect interim coutractor

Working plan by interim contractor - initiate work

Survey sites and annual modules

Land ćlèàînğ (salvage wood)

Take over by final contractor

Initlate and contract land preparation

Land preparation

Inttiate and contract well drilling

Delivery of well equipment

Well drilling and installation

Initiate and contract irrigation system

Delivery of irrigation equipment

Installation of irrigation mains

Test wells, irrigation mains, site inspection

Survey of first modules (roads, etc.)

Order planting equipment

Delivery of planting equipment

Combine planting and irrigation equipment - bids for planting work

Test planting equipment - select planting contractor

Order vehicles

Delivery vehicles

Install buildings and services (septic field, power line, etr.)

Delivery of buildings and service equipment and materials

Initiate and contract for buididings and services

Initiate and contract for research equipment

Delivery of research equipment

Installation or research equipment

Recruiting of field persunnel

Hiring of field personnel

Field personnel takes over day-to-day management

Specifications for cultivation work

Receive bids for cultivation work

Contract fur cultivation work

$1_{\text {See Figure } 11 .}$ 


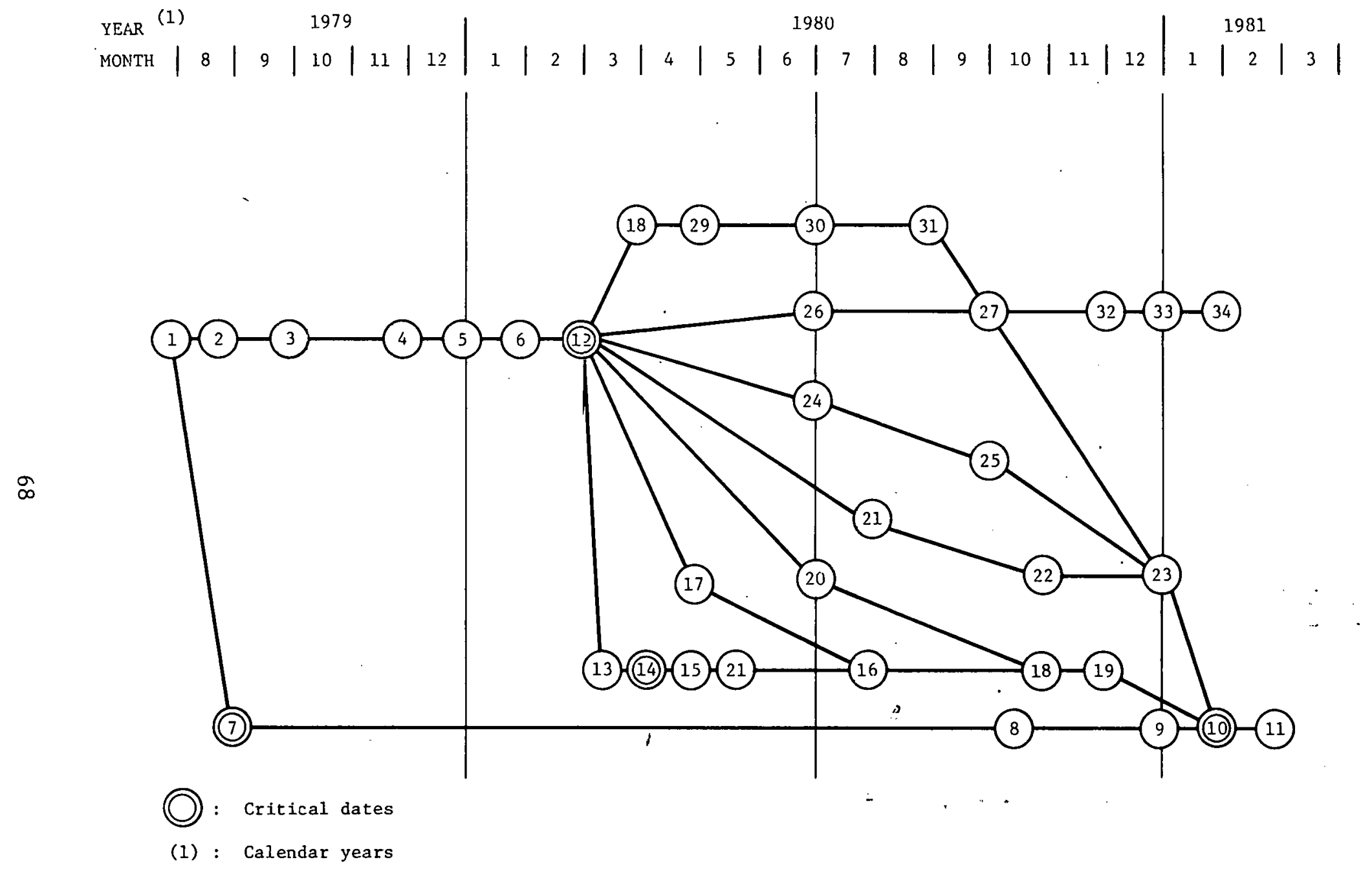

FIGURE 12

SCHEDULE OF INSTALLATION OF MODULE I

(OPTION 2: LAND CLEARING WITH NO WOOD RECOVERY) 
TABLE XVII

OPERATIONS FOR SCHEDULE OF INSTALLATION OF FIRST MODULES

(Option 2 - Land Clearing Without Wood Recovery)

PATH $^{1}$

1-2

2-3

3-4

4-5

5-6

6-12

$1-7$

$7-8$

8-9

9-10

$10-11$

$12-13$

13-14

14-15

15-21

21-16

12- 17

$1.7-16$

16-18

$18-19$

19-10

12-20

20-18

12-21

$21-22$

22-23

23-10

12-24

24-25

25-23

12-26

26-27

27-23

$12-28$

28-29

$29-30$

$30-31$

$31-27$

$27-32$

$32-33$

$33=34$

\section{OPERATIONS}

Prepare RFP

Issue RFP

Receive proposals

Select contractor

Finalize contract

Finalize detailed plans by contractor

Order seedlings

Seedlings production (nursery)

Seedlings storage (nursery)

Seedling delivery

Planting and irrigation pipes in place

Initiato and rontrart for land clearing and preparation

Survey of sites and annual modules

Land clearing

Survey of first modules (roads, etc.)

Land Preparation

Initiale and contract for well drilling

Delivery of well equipment

Well drilling and installation

Installation of irrigation mains

Test wells, irrigation mains, site inspection

Initiate and contract irrigation system

Delivery of irrigation equipment

Order planting equipment

Delivery of plantins, equipment.

Combine planting and irrigation equipment - bids for plant work

Test planting equipment - select planting operator

Initiate and contract for buildings and services

Delivery of buildings and service equipment and materials

Installation of buildings and services (septic fields, power line, etc.)

Initiate and contract for research eyuipiment

Delivery of research equipment

Installation of research equipulent

Order vehicles

Delivery of vehicles

Recruiting of field personnel

Hiring of field personnel

Field personnel takes over day-to-day management

Speciflcatluns füi cultivation work

Receive bids for cultivation work

Contract for cultivation work

${ }^{1}$ See Figure 12. 


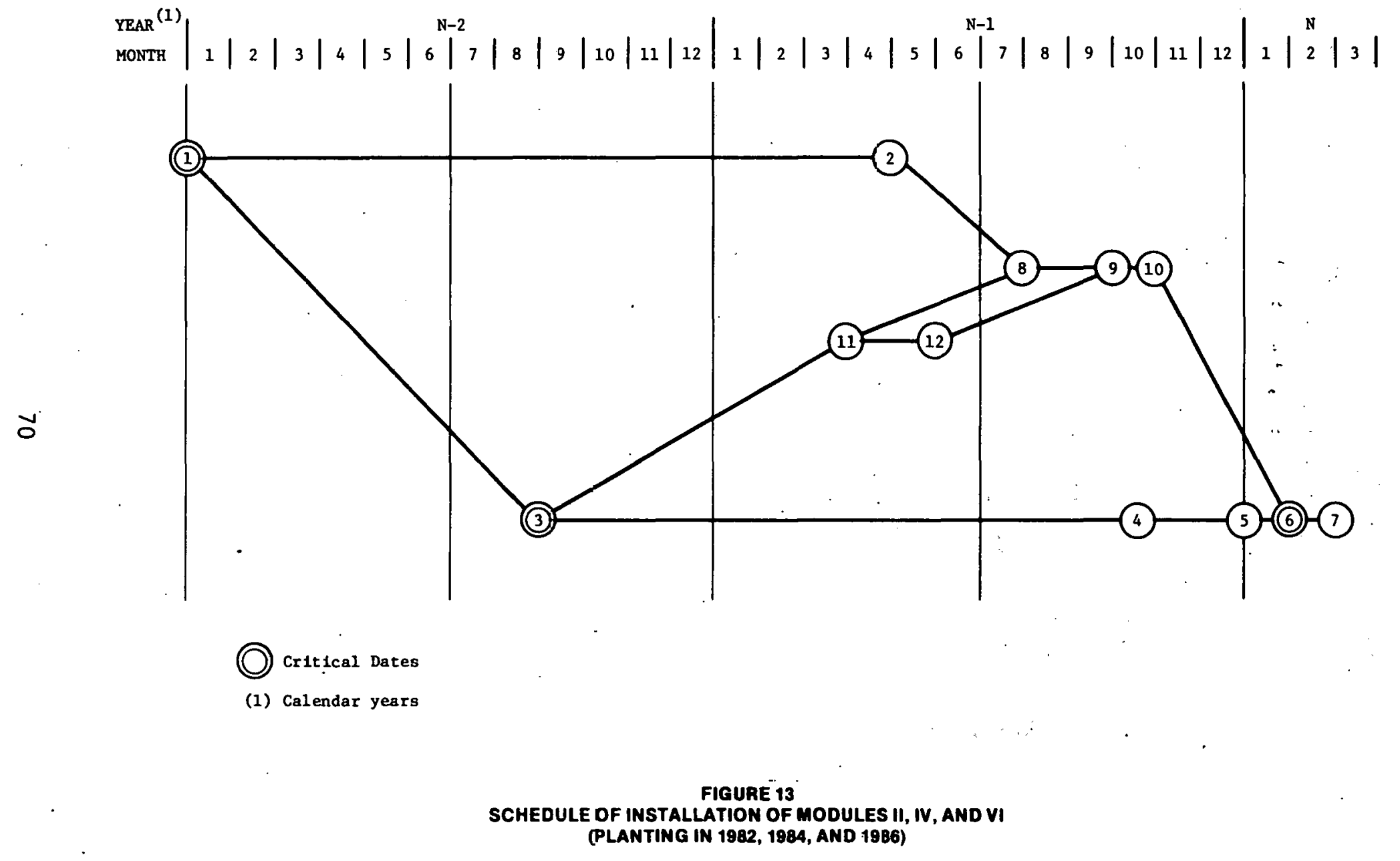


OPERATIONS FOR SCHEDULE OF INSTALLATION

OF MODULES TWO, FOUR AND SIX

(PLANTING IN 1982,1984 , AND 1986)

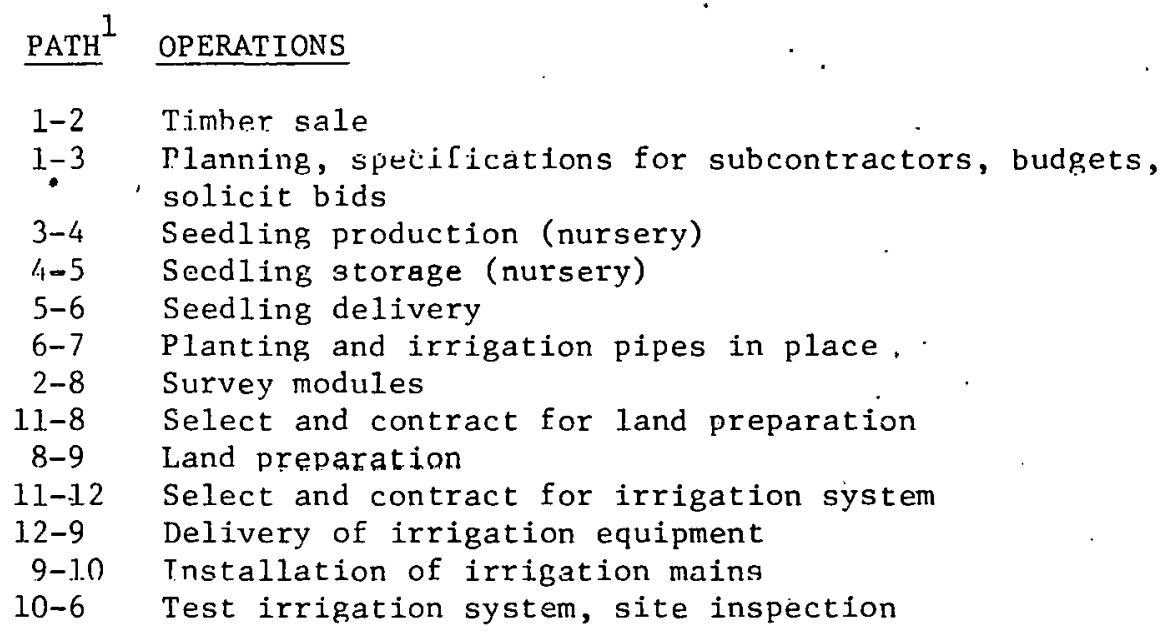

$\overline{1}_{\text {See Figure } 13 .}$ 


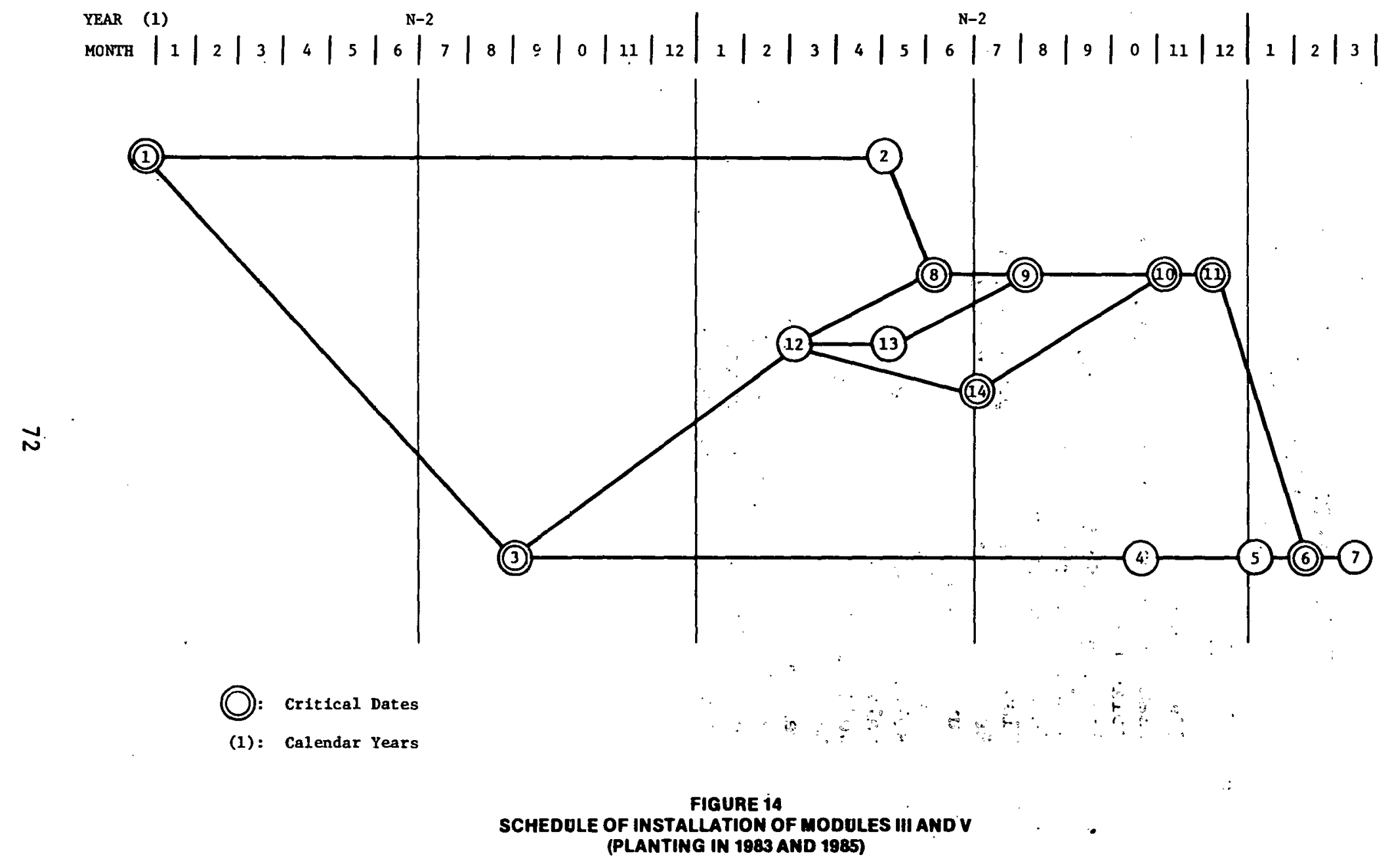




\section{TABLE XIX}

OPERATIONS FOR SCHEDULE OF INSTALLATION

OF MODILES THREE AND FIVE

(PLANTING IN 1983 AND 1985)

\section{PATH $^{1}$ OPERATIONS}

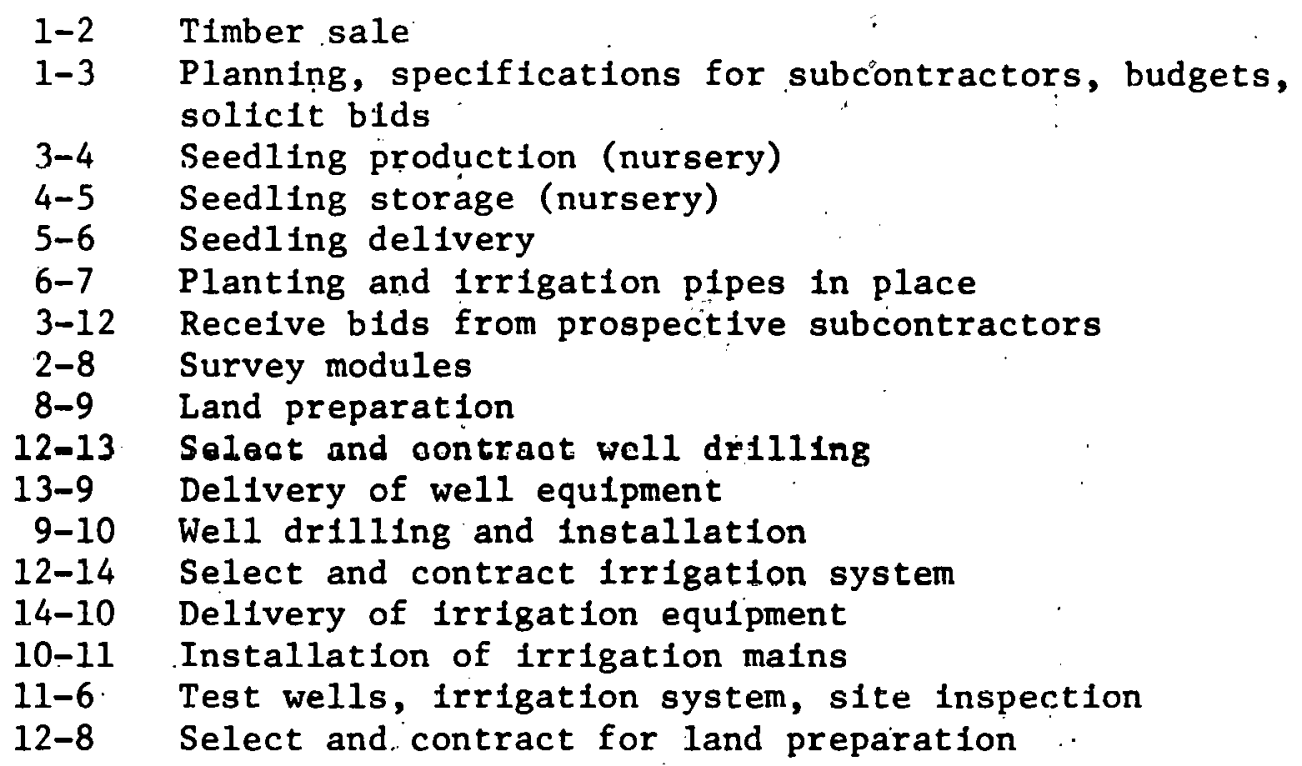

$1_{\text {See Figure } 14 .}$ 
in the timber sale schedule (path 1-2) and there is considerable flexibility in other schedules.

Installation of Modules III and V

Wells must be installed as a part of the installation of modules III and V. This will occur the year before planting.

The schedule of operations to establish modules III and $V$ is presented in Figure 14 and Table XIX. For a planting deadline of February 1, Year $N(N=1983$ or 1985) the following dates are critical:

- January 1, Year $\mathrm{N}$ minus 2, timber sale initiated;

- September 1, Year $\mathrm{N}$ minus 2, seedlings ordered; and

- February 1, Year $\mathrm{N}$, seedlings planted.

Meeting schedules for the timber sale (path 1-2) and seedling acquisition (path $3-7$ ) is critical if modules III and $V$ are to be installed as planned. There is some flexibility in other schedules. Sumary of planting Schedule

The schedule of operations leading to the final installation of the PSBF by March 1, 1986 is summarized in Figure 15. The time required for each major operation is indicated by a continuous 1 ine and important deadlines are indicated.

It should be stressed that the planning proposed in Figure 15 lends itself to some modification provided the critical deadlines are met. For instance, a single timber sale resulting in the clearing of several annual modules, rather than yearly timber sales for individual modules might be preferred. Also, it may be preferred to drill 


\begin{tabular}{|c|c|c|c|c|c|c|c|c|c|}
\hline MODULE & 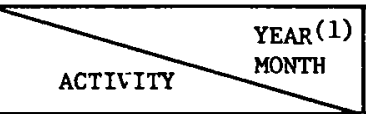 & $\begin{array}{ccc} & 679 \\
8 & 10 & 12\end{array}$ & $\begin{array}{c}1980 \\
24681012\end{array}$ & 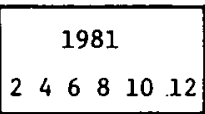 & 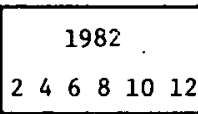 & 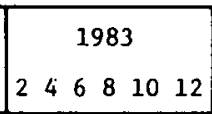 & $\begin{array}{rl} & 1984 \\
24 & 681012\end{array}$ & 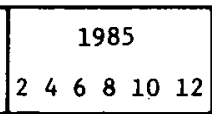 & 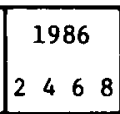 \\
\hline ALL & $\begin{array}{l}\text { PLANNINC - CONIRACTOR } \\
\text { SELECTION. }\end{array}$ & & סמ & & & & & & \\
\hline I & $\begin{array}{l}\text { LAND CLEARING } \\
\text { LAND PREPARATION } \\
\text { IRRIGATION AND WELLS } \\
\text { SEEDLINGS - PLANTING }\end{array}$ & 10 & a & م & & . & & & \\
\hline II & $\begin{array}{l}\text { LAND CLEARING } \\
\text { LAND PREPARATION } \\
\text { IRRIGATION } \\
\text { SEEDLINGS - PLANTING }\end{array}$ & & & & ם & & & & \\
\hline III & $\begin{array}{l}\text { LAND CLEARING } \\
\text { LAND PREPARATION } \\
\text { IRRIGATIJN AND WELLS } \\
\text { SEZDLINGS - PLANTING }\end{array}$ & . & & & & & : & & \\
\hline IV & $\begin{array}{l}\text { LAVD CLEARING } \\
\text { LAND PREPARATION } \\
\text { IRRIGATIDN } \\
\text { SEZDLINGS - PLANTING }\end{array}$ & & & & & & U & & \\
\hline $\mathbf{v}$ & $\begin{array}{l}\text { LAND CLEARING } \\
\text { IAND PREPARATION } \\
\text { IRRIGATION } \\
\text { SEEDLINGS - PLANTING }\end{array}$ & 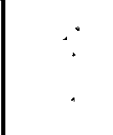 & & & . & & - & 1. & \\
\hline vI & $\begin{array}{l}\text { LAADD CLEARING } \\
\text { LARD PREPARATION } \\
\text { IRRIGATION } \\
\text { SEEDLINGS - PLANTING }\end{array}$ & & & , & - & & $\sigma$ & & \\
\hline ALL & $\begin{array}{l}\text { ORDERING AND DELIVERY } \\
\text { OF HARVESTING EQUTPMENT. }\end{array}$ & & & & & & 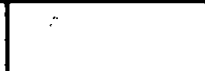 & & \\
\hline
\end{tabular}

D CRITICAL DATES

(1) CALENDAR YEARS

FIGURE 15

SUMMAAYY SCHEDULE FOR THE INSTALLATION OF THE

PILOT SILVICULTURAL BIOMASS FARM 
all wells at one site the first year and to install the pumping equipment when the wells are scheduled for service. Such day-to-day decisions will be made by the contractor, DOE, and field personnel on the basis of discussions with and recommendations from the subcontractors involved.

Operation Plan for the Pilot Silvicultural Biomass Farm

The operation of the PSBF involves a number of annual field operations. Some of these operations, such as irrigation and fertilization, occur every year in every module. Others, such as harvesting, occur. only occasionally.

The schedule of the field operations required for a given year are summarized in Figure 16. All planted modules will be irrigated and fertilized between March 15 and September 15 during each year of a rotation. Actual irrigation and fertilization requirements will vary from year to year and will depend upon factors such as weather conditions and stand age.

Each module will be harvested after the sixth year of growth. All harvesting operations will be completed during the dormant season and may therefore occur during portions of two calendar years. Roads will be repaired and irrigation tubing will be replaced after each module is harvested.

The design of. the PSBF includes the planting of one-fourth of Modules I and II with slash pine. It will be necessary to replant these areas after each harvest because slash pine will not coppice. 


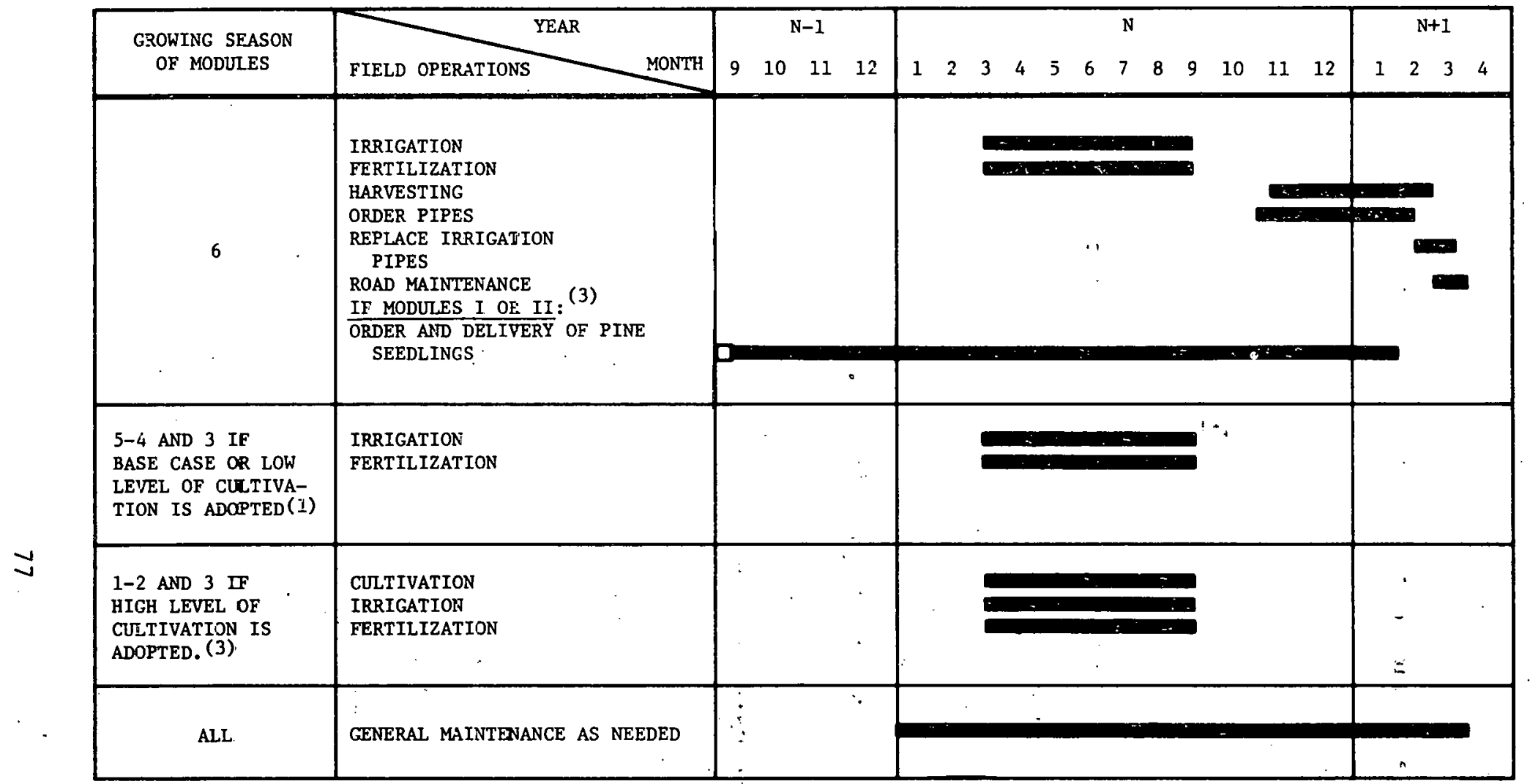

(1) Low level or base case cultivation: cultivation during the growing season for the first two years of a rotation (see Section IV).

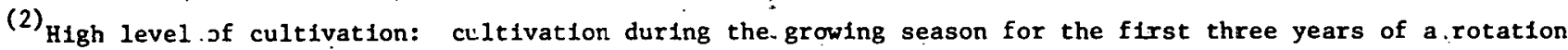
(see Section IV)

(3) One fourth of the area of modules I anc II are planted in slash pine, which have to be replanted after harvest.

a Critical date. 
THIS PAGE

WAS INTENTIONALLY

LEFT BLANK 


\section{COST ESTIMATES FOR INSTALLATION AND OPERATION}

Cost estimates for the installation and operation of the PSBF were developed. These estimates are based on prices quoted by various local and regional contractors and are reported in 1978 dollars. Yearly budgets were developed for Federal Government Fiscal Years (FY), i.e., October 1 to September 30 of the next year, starting with FY 1979 (October 1, 1978 to September 30, 1979).

The estimated installation costs for the Jackson and Route 278 oitoc are sbown in Tables XX and XXI, respectively. These costs are itemized by Fiscal Year and by type of operation. Most costs are associated with the development of a given module at each site during each year. Planting, however, occurs the year after land clearing and site preparation. The expense of drilling irrigation wells is incurred only every other FY as each well supplies water to two modules.

No credit was taken for the salvage (Modules I, Option 1) or sale of timber (modules II - VI) present on the land. No cost is quoted for the purchase of seedlings for Modules I as thc ocedlings will be ordered during FY 1979.

Item 16 in Table $\mathrm{XX}$, harvesting support equipment refers to the purchase of two dump wagons for the collection and transportation of the wood chips. No cost is included for the purchase of a harvester because a prototype harvester is presently being developed and should be available by the end of the first rotation of Modules I. 
TABLE XX

INSTALLATION COSTS - JACKSON SITE

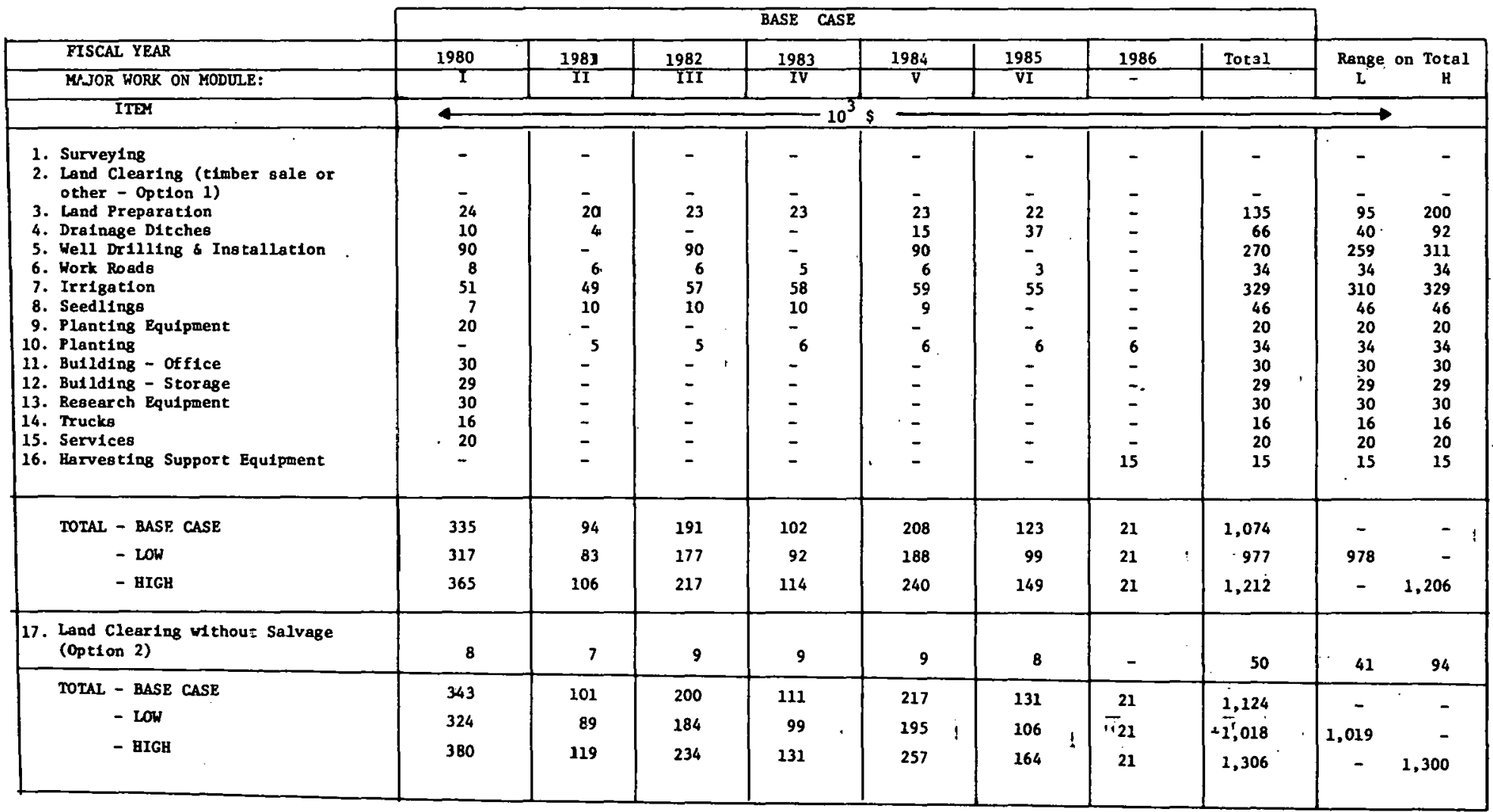


TABLE XXI

INSTALLATION COSTS - ROUTE 278 SITE

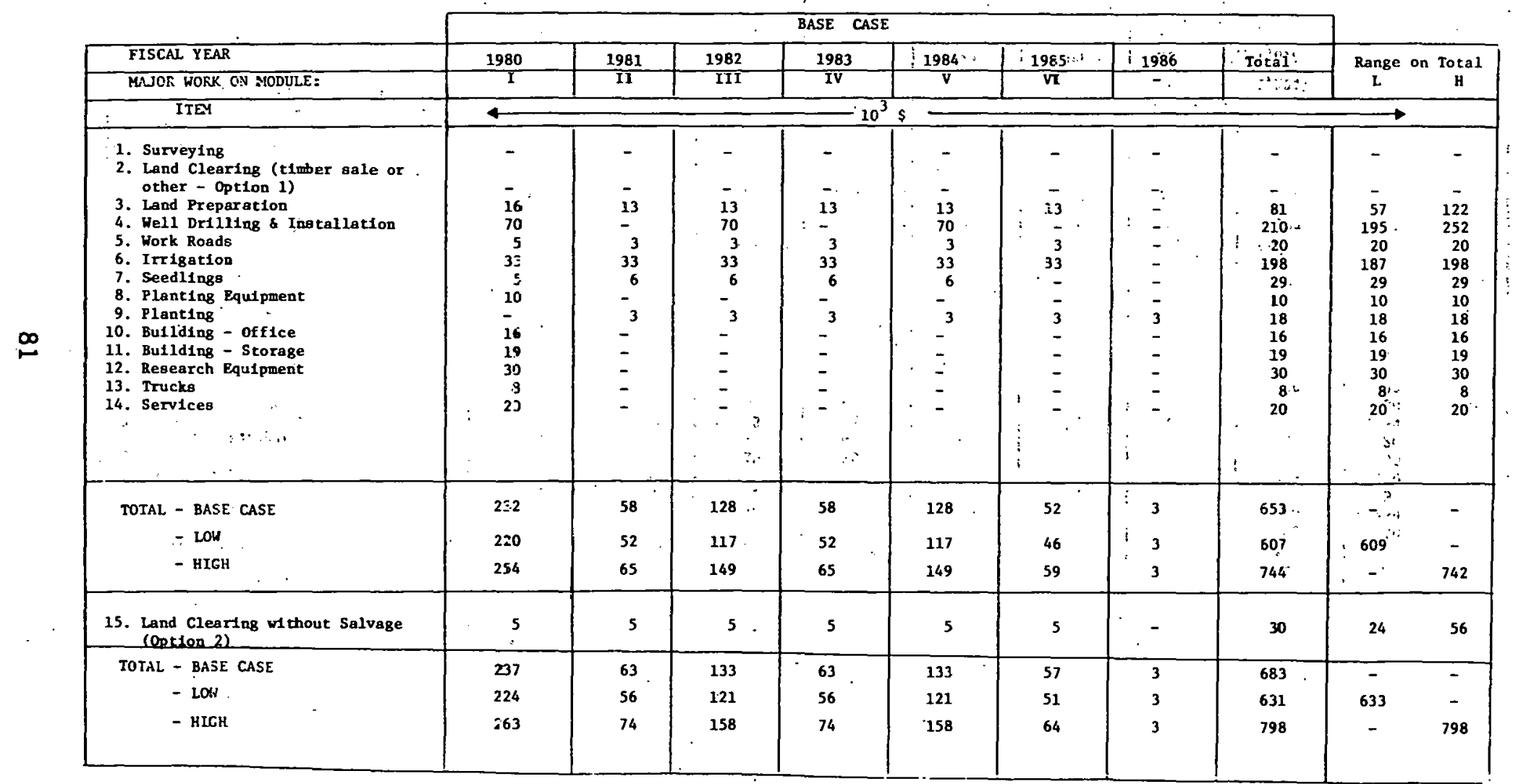


The low and high costs reflect the uncertainty which can be expected on the cost of some of the major tasks required to install the PSBF. The anticipated fluctuations in total installation cost is of the order of plus or minus 10 to 15 percent of the base case cost. Major areas of uncertainty include the cost of land preparation, the cost of drainage ditches and the cost of the irrigation system. Summaries of installation costs at both sites are presented in Table XXII by major components and by fiscal years. Nearly 60 percent of the total installation cost can be allocated to the capital cost of the irrigation system. Land preparation is the second highest cost item and contributes almost 20 percent of the total. Buildings, services and equipment account for about 15 percent. This relatively large contribution by miscellaneous purchases is not necessarily representative of a commercial operation in which, for example, a single office building should be adequate for a muil larger farm than the PSBF. Finally, the cost of the seedlings and their planting is the smallest item in the installation budget. Operation Cost Estimates

Cost estimates for the operation of the PSBF were developed for the base case design discussed above. Table XXIII summarizes the expected operating costs by fiscal year and line item. The base case for each operation was described above. The low and high cases correspond to variations in the level or intensity of management and not in the costs which are the same as those used for the base case. 
TABLE XXII

SUMPARY OF INSTALLATION COSTS FOR THE PILOT SILVICULTURAL BIOMASS PARM (JACRSON AND ROUTE 278 SITES) ${ }^{(1)}$

\begin{tabular}{|c|c|c|c|c|c|c|c|c|c|}
\hline \multirow[b]{2}{*}{ FISCAL YEAR } & \multicolumn{8}{|c|}{$10^{3} s$} & \multirow{2}{*}{$\begin{array}{c}\text { Percentage of } \\
\text { Total } \\
\text { Percent }\end{array}$} \\
\hline & 1980 & 1.981 & 1982 & 1983 & 1986 & 1985 & 1986 & Total (2) & \\
\hline $\begin{array}{l}\text { ITEAS: } \\
\text { 1. Site Improvenent (roads, } \\
\text { ditches) } \\
\text { 2. Land Preparation } \\
\text { 3. Total }\end{array}$ & $\begin{array}{l}23 \\
\frac{40}{63}\end{array}$ & $\begin{array}{l}13 \\
\frac{33}{46}\end{array}$ & $\begin{array}{r}9 \\
36 \\
45\end{array}$ & $\begin{array}{r}8 \\
36 \\
44\end{array}$ & $\begin{array}{r}24 \\
-35 \\
60\end{array}$ & $\begin{array}{r}43 \\
35 \\
78\end{array}$ & E & $\begin{array}{l}120 \\
\frac{216}{33.6}\end{array}$ & $\begin{array}{r}6.9 \\
12.5 \\
19.4\end{array}$ \\
\hline $\begin{array}{l}\text { 4. Irrigation PLping } \\
\text { 5. Hells } \\
\text { 6. Total }\end{array}$ & $\begin{array}{r}84 \\
\frac{160}{244}\end{array}$ & $\frac{82}{82}$ & $\begin{array}{r}90 \\
160 \\
250\end{array}$ & $\frac{91}{91}$ & $\begin{array}{r}92 \\
\frac{160}{252}\end{array}$ & $\frac{\mathrm{BB}}{\mathrm{B8}}$ & $\begin{array}{l}- \\
-\end{array}$ & $\begin{array}{r}527 \\
1,080 \\
, 007\end{array}$ & $\begin{array}{l}30.4 \\
\frac{27.7}{58.1}\end{array}$ \\
\hline $\begin{array}{l}\text { 7. Seedlings } \\
\text { 8. Planting } \\
\text { 9. Total }\end{array}$ & $\frac{12}{12}$ & $\begin{array}{r}16 \\
8 \\
24\end{array}$ & $\begin{array}{r}16 \\
\frac{8}{24}\end{array}$ & $\begin{array}{r}16 \\
\frac{9}{25}\end{array}$ & $\begin{array}{r}15 \\
9 \\
24\end{array}$ & $\frac{\overline{9}}{9}$ & $\frac{\overline{9}}{9}$ & $\begin{array}{r}75 \\
\frac{52}{127}\end{array}$ & $\begin{array}{l}4.3 \\
\frac{3.0}{7.3}\end{array}$ \\
\hline $\begin{array}{l}\text { 10. Bu1ld1ags, Services, } \\
\text { Equipment }\end{array}$ & 248 & - & - & - & - & - & 15 & 203 & 15.2 \\
\hline TOTAL - BASE CASE & 567 & 152 & 319 & 160 & 336 & 175 & 24 & 1,733 & 100.0 \\
\hline - LOW & 537 & 135 & 294 & 144 & 305 & 145 & 24 & 1,584 & 91.4 \\
\hline - HIGH & 619 & 171 & 366 & 179 & 389 & 208 & 24 & 1,956 & 112.9 \\
\hline
\end{tabular}

(1) Land clearing jy oalvage sale (Option 1) No credit for timber sale

78 Dollars

(2) Total costs in dollans (not $10^{3}$ \$) are aloo cost per acre/planted. 


\section{THIS PAGE}

\section{WAS INTENTIONALLY \\ LEFT BLANK}




\begin{tabular}{|c|c|c|c|c|c|c|c|c|c|c|c|c|c|c|c|c|c|c|c|c|c|c|c|c|c|}
\hline ERATION FISCAL YEAR & 1980 & 1981 & 1982 & 1983 & 1984 & 1985 & 1986 & 1987 & 1988 & 1989 & 1990 & 1991 & 1992 & 1993 & 1994 & 1995 & 1996 & 1997 & 1998 & 1999 & 2000 & 2001 & 2002 & 2003 & TotaL \\
\hline curtivarton - $\begin{array}{r}\mathrm{BC} \\
\mathrm{H} \\
\mathrm{H}\end{array}$ & $\overline{-}$ & $\begin{array}{l}11 \\
8 \\
16\end{array}$ & $\begin{array}{l}19 \\
13 \\
25\end{array}$ & $\begin{array}{l}20 \\
13 \\
28 \\
28\end{array}$ & $\begin{array}{l}21 \\
14 \\
29\end{array}$ & $\begin{array}{l}21 \\
14 \\
29\end{array}$ & $\begin{array}{l}20 \\
14 \\
29\end{array}$ & $\begin{array}{l}20 \\
13 \\
28 \\
\end{array}$ & $\begin{array}{l}19 \\
13 \\
27\end{array}$ & $\begin{array}{l}20 \\
13 \\
28 \\
\end{array}$ & $\begin{array}{l}21 \\
14 \\
29 \\
\end{array}$ & $\begin{array}{l}21 \\
14 \\
29 \\
\end{array}$ & $\begin{array}{l}20 \\
14 \\
28 \\
\end{array}$ & \begin{tabular}{|l}
20 \\
13 \\
28 \\
\end{tabular} & $\begin{array}{l}19 \\
13 \\
27 \\
\end{array}$ & $\begin{array}{l}20 \\
13 \\
28 \\
\end{array}$ & $\begin{array}{l}21 \\
14 \\
29 \\
\end{array}$ & $\begin{array}{l}21 \\
14 \\
29 \\
\end{array}$ & $\begin{array}{l}20 \\
14 \\
29\end{array}$ & $\begin{array}{l}20 \\
13 \\
28 \\
\end{array}$ & $\begin{array}{l}19 \\
13 \\
27 \\
\end{array}$ & $\begin{array}{l}20 \\
13 \\
28\end{array}$ & $\begin{array}{l}21 \\
14 \\
29\end{array}$ & $\begin{array}{l}21 \\
14 \\
29\end{array}$ & $\begin{array}{l}455 \\
305 \\
63 ?\end{array}$ \\
\hline $\begin{array}{r}\text { IRRICATION - BC- Fue1 } \\
\text { Tubing } \\
\text { Totat } \\
\text { H } \\
\text { Totata1 } \\
\end{array}$ & $\underline{E}$ & $\begin{array}{c}\frac{5}{5} \\
5 \\
\end{array}$ & \begin{tabular}{|l}
$\frac{10}{10}$ \\
$\frac{11}{11}$ \\
\end{tabular} & $\frac{\frac{15}{15}}{1.7}$ & $\begin{array}{l}\frac{20}{20} \\
20 \\
22\end{array}$ & $\begin{array}{l}\frac{26}{26} \\
28 \\
\end{array}$ & $\begin{array}{l}\frac{31}{31} \\
34\end{array}$ & $\begin{array}{l}31 \\
\frac{37}{68} \\
71\end{array}$ & $\begin{array}{l}\frac{31}{36} \\
\frac{67}{70} \\
\end{array}$ & $\begin{array}{l}31 \\
\frac{39}{70} \\
73\end{array}$ & $\begin{array}{l}31 \\
\frac{40}{71} \\
74 \\
44\end{array}$ & $\begin{array}{l}31 \\
40 \\
71 \\
74 \\
\end{array}$ & $\begin{array}{l}31 \\
39 \\
70 \\
73 \\
3\end{array}$ & $\begin{array}{r}31 \\
37 \\
68 \\
71\end{array}$ & $\begin{array}{l}\frac{31}{36} \\
\frac{367}{67} \\
70\end{array}$ & $\begin{array}{l}31 \\
\frac{39}{.70} \\
.73 \\
\end{array}$ & $\begin{array}{r}31 \\
\frac{40}{71} \\
74 \\
\end{array}$ & $\begin{array}{l}31 \\
\frac{40}{71} \\
74 \\
\end{array}$ & $\begin{array}{l}31 \\
39 \\
70 \\
73 \\
\end{array}$ & $\begin{array}{l}31 \\
37 \\
68 \\
71\end{array}$ & $\begin{array}{l}31 \\
\frac{36}{67} \\
70 \\
\end{array}$ & \begin{tabular}{|c|}
31 \\
39 \\
70 \\
73 \\
\end{tabular} & $\begin{array}{l}31 \\
\frac{30}{71} \\
74 \\
\end{array}$ & \begin{tabular}{|l|}
31 \\
70 \\
74 \\
\end{tabular} & $\begin{array}{l}\frac{634}{634} \\
\frac{545}{1,288} \\
1,349\end{array}$ \\
\hline 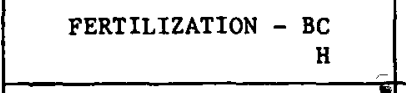 & $=$ & $\frac{1}{2}$ & $\begin{array}{r}6 \\
12 \\
\end{array}$ & $\begin{array}{l}13 \\
26 \\
\end{array}$ & $\begin{array}{l}22 \\
44 \\
\end{array}$ & $\begin{array}{r}33 \\
66 \\
\end{array}$ & $\begin{array}{r}46 \\
92 \\
\end{array}$ & $\begin{array}{r}47 \\
94 \\
\end{array}$ & $\begin{array}{l}48 \\
96 \\
\end{array}$ & \begin{tabular}{|l}
47 \\
94 \\
\end{tabular} & $\begin{array}{r}47 \\
94 \\
\end{array}$ & \begin{tabular}{|l|l}
46 \\
92 \\
\end{tabular} & $\begin{array}{l}46 \\
92 \\
\end{array}$ & $\begin{array}{r}47 \\
94 \\
\end{array}$ & $\begin{array}{l}48 \\
96 \\
\end{array}$ & $\begin{array}{l}47 \\
94 \\
\end{array}$ & $\begin{array}{l}47 \\
94 \\
\end{array}$ & $\begin{array}{l}46 \\
92 \\
\end{array}$ & $\begin{array}{l}46 \\
92 \\
\end{array}$ & $\begin{array}{l}47 \\
94\end{array}$ & $\begin{array}{l}48 \\
96 \\
\end{array}$ & $\begin{array}{l}47 \\
94\end{array}$ & $\begin{array}{l}47 \\
94 \\
\end{array}$ & $\begin{array}{l}46 \\
92 \\
9\end{array}$ & $\begin{array}{r}318 \\
1,836 \\
\end{array}$ \\
\hline 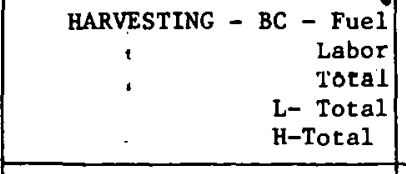 & $\begin{array}{l}=- \\
=- \\
=-\end{array}$ & $\bar{\Xi}$ & $\begin{array}{l}-- \\
\overline{-} \\
--- \\
\end{array}$ & $\underline{\Xi}$ & $\begin{array}{l}=- \\
=- \\
--\end{array}$ & $\begin{array}{l}= \\
=- \\
--\end{array}$ & $\begin{array}{l}= \\
= \\
--\end{array}$ & $\begin{array}{c}7 \\
\frac{10}{17} \\
11 \\
21 \\
\end{array}$ & $\begin{array}{r}7 \\
-\frac{10}{17} \\
11 \\
21 \\
\end{array}$ & $\begin{array}{r}7 \\
\frac{11}{18} \\
11 \\
23 \\
\end{array}$ & $\begin{array}{l}\frac{71}{11} \\
18 \\
11 \\
23\end{array}$ & $\begin{array}{r}7 \\
-11 \\
18 \\
11 \\
23 \\
\end{array}$ & $\begin{array}{c}71 \\
\frac{11}{18} \\
11 \\
23 \\
\end{array}$ & $\begin{array}{r}7 \\
10 \\
11 \\
11 \\
21 \\
\end{array}$ & $\begin{array}{r}7 \\
10 \\
17 \\
11 \\
21 \\
\end{array}$ & $\begin{array}{l}7 \\
11 \\
18 \\
11 \\
23 \\
\end{array}$ & $\begin{array}{r}7 \\
11 \\
11 \\
11 \\
23 \\
\end{array}$ & $\begin{array}{l}7 \\
\frac{11}{18} \\
11 \\
23 \\
\end{array}$ & $\begin{array}{r}7 \\
11 \\
118 \\
11 \\
23 \\
\end{array}$ & $\begin{array}{l}7 \\
\frac{10}{17} \\
11 \\
21 \\
\end{array}$ & $\begin{array}{r}7 \\
\frac{10}{17} \\
11 \\
21 \\
\end{array}$ & $\begin{array}{r}7 \\
\frac{11}{18} \\
\frac{11}{23} \\
\end{array}$ & $\begin{array}{l}7 \\
11 \\
18 \\
11 \\
23 \\
\end{array}$ & \begin{tabular}{|c|}
1 \\
18 \\
11 \\
21 \\
\end{tabular} & $\begin{array}{l}119 \\
\frac{119}{310} \\
137 \\
379\end{array}$ \\
\hline 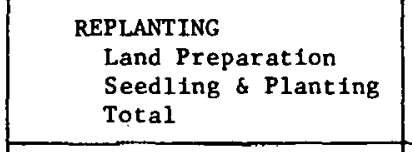 & $=$ & $\underline{-}$ & $\bar{z}$ & $\equiv$ & $\ddot{-}$ & $\frac{-1}{1}$ & $\frac{-1}{1}$ & $\begin{array}{r}8 \\
\frac{2}{10} \\
\end{array}$ & $\begin{array}{r}8 \\
\frac{2}{10} \\
\end{array}$ & $=$ & $\overline{-}$ & $\frac{1}{1}$ & $\frac{-1}{1}$ & $\frac{2}{10}$ & $\frac{2}{10}$ & $\overline{-}$ & $\bar{z}$ & $\frac{-1}{1}$ & $\frac{-1}{1}$ & $\begin{array}{r}8 \\
\frac{2}{10} \\
\end{array}$ & $\begin{array}{r}8 \\
\frac{2}{10} \\
\end{array}$ & $\bar{z}$ & 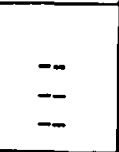 & $\bar{z}$ & $\begin{array}{l}48 \\
\frac{18}{66}\end{array}$ \\
\hline MALINTEANCE \& REPATR & 2 & 9 & 9 & 11 & 11 & 13 & 13 & 32 & 30 & 30 & 29 & 30 & 28 & 32 & 30 & 30 & 29 & 30 & 28 & 32 & 30 & 30 & 29 & 30 & 577 \\
\hline 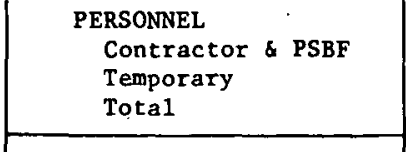 & $\begin{array}{r}200 \\
\frac{3}{203} \\
\end{array}$ & $\begin{aligned} 200 \\
203 \\
\end{aligned}$ & $\begin{array}{r}200 \\
\frac{3}{203} \\
\end{array}$ & $\frac{200}{203}$ & $\begin{array}{r}\frac{200}{203} \\
203 \\
\end{array}$ & $\begin{array}{l}200 \\
\frac{3}{203} \\
\end{array}$ & $\begin{array}{r}200 \\
\frac{3}{203} \\
\end{array}$ & $\begin{array}{r}200 \\
\frac{3}{203} \\
\end{array}$ & $\begin{array}{r}200 \\
\frac{200}{203} \\
\end{array}$ & \begin{tabular}{|l}
200 \\
3 \\
203 \\
\end{tabular} & $\begin{array}{l}200 \\
\frac{3}{203} \\
\end{array}$ & $\begin{array}{l}\frac{200}{3} \\
203 \\
\end{array}$ & $\begin{array}{r}200 \\
203 \\
203 \\
\end{array}$ & $\begin{array}{l}200 \\
\frac{3}{203} \\
\end{array}$ & $\begin{array}{r}200 \\
\frac{3}{203} \\
\end{array}$ & $\begin{array}{r}200 \\
\frac{3}{203} \\
\end{array}$ & $\begin{array}{r}200 \\
\frac{3}{203} \\
\end{array}$ & $\begin{array}{r}200 \\
\frac{3}{203} \\
\end{array}$ & $\begin{array}{l}200 \\
\frac{3}{203} \\
\end{array}$ & $\begin{array}{l}200 \\
\frac{3}{203} \\
\end{array}$ & $\begin{array}{l}\frac{200}{3} \\
203 \\
203\end{array}$ & $\begin{array}{r}200 \\
\frac{3}{203} \\
\end{array}$ & $\begin{array}{r}\frac{200}{203} \\
\end{array}$ & $\begin{array}{l}200 \\
\frac{3}{203} \\
\end{array}$ & \begin{tabular}{|l}
4.800 \\
$\frac{72}{4,872}$ \\
4.2
\end{tabular} \\
\hline UTILITIES \& SERVICES & 6 & 12 & 12 & 12 & 12 & 12 & 12 & 12 & 12 & 12 & 12 & 12 & 12 & 12 & 12 & 12 & 12 & 12 & 12 & 12 & 12 & 12 & 12 & 12 & 282 \\
\hline $\begin{array}{l}\text { EQUTPYENT REPLACEMENT } \\
\text { Trucks } \\
\text { Tractor } \\
\text { Irrtgattion Pumps } \\
\text { Wragons } \\
\text { Planters } \\
\text { Miscellaneous } \\
\text { TotaL }\end{array}$ & $\begin{array}{l}= \\
= \\
\frac{-5}{5}\end{array}$ & $\begin{array}{l}z \\
\bar{z} \\
\frac{5}{5} \\
\frac{-}{5}\end{array}$ & $\begin{array}{c}z- \\
=- \\
z- \\
\frac{5}{5} \\
\end{array}$ & $\begin{array}{l}= \\
\equiv \\
= \\
\frac{5}{5} \\
5\end{array}$ & $\begin{array}{l}-z \\
z- \\
-- \\
\frac{-}{5} \\
\end{array}$ & $\begin{array}{l}= \\
=- \\
-\because \\
\frac{5}{5} \\
\end{array}$ & $\begin{array}{l}= \\
= \\
= \\
\frac{5}{5}\end{array}$ & $\begin{array}{c}-- \\
\overline{--} \\
\overline{-} \\
5 \\
\end{array}$ & $\begin{array}{l}z \\
= \\
\frac{5}{5} \\
5\end{array}$ & $\begin{array}{c}-- \\
--- \\
-- \\
-5 \\
5\end{array}$ & $\begin{array}{r}24 \\
20 \\
-- \\
-5 \\
\frac{5}{49} \\
\end{array}$ & $\begin{array}{l}= \\
\frac{z}{30} \\
\frac{5}{35}\end{array}$ & $\begin{array}{l}-- \\
-- \\
-- \\
\frac{5}{5} \\
5\end{array}$ & $\begin{array}{c}-- \\
-- \\
-- \\
-5 \\
5 \\
\end{array}$ & $\begin{array}{c}-- \\
-- \\
-- \\
-5 \\
5 \\
\end{array}$ & \begin{tabular}{c|}
-- \\
-- \\
-- \\
-5 \\
5 \\
\end{tabular} & $\begin{array}{r}\frac{7}{45} \\
\frac{15}{-5} \\
\frac{5}{5} \\
\end{array}$ & $\begin{array}{l}\overline{-\bar{z}} \\
\overline{--} \\
\overline{-3} \\
\frac{3}{5} \\
\end{array}$ & $\begin{array}{r}-- \\
45 \\
-- \\
\frac{5}{50} \\
\end{array}$ & $\begin{array}{l}= \\
=- \\
\frac{-}{5} \\
\frac{5}{5}\end{array}$ & $\begin{array}{r}24 \\
20 \\
45 \\
30 \\
5 \\
124 \\
\end{array}$ & $\begin{array}{r}7 \\
-Z \\
7- \\
\frac{5}{5} \\
\end{array}$ & $\begin{array}{c}z- \\
\bar{z} \\
\frac{-}{5} \\
\frac{5}{5}\end{array}$ & $\begin{array}{l}\frac{Z}{Z} \\
\frac{Z}{5} \\
\frac{5}{5}\end{array}$ & $\begin{array}{r}48 \\
40 \\
135 \\
15 \\
60 \\
120 \\
118 \\
\end{array}$ \\
\hline 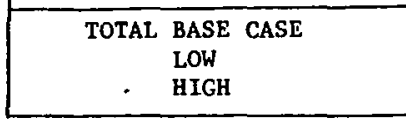 & \begin{tabular}{|l|l|}
216 \\
216 \\
216 \\
216
\end{tabular} & $\begin{array}{l}246 \\
\text { 243 } \\
252 \\
\end{array}$ & \begin{tabular}{|l|l|}
264 \\
as8 \\
277 \\
\end{tabular} & 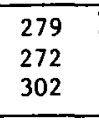 & $\begin{array}{l}294 \\
287 \\
326 \\
326\end{array}$ & $\begin{array}{l}314 \\
3107 \\
357 \\
\end{array}$ & $\begin{array}{l}331 \\
325 \\
389 \\
\end{array}$ & $\begin{array}{l}414 \\
401 \\
476 \\
\end{array}$ & $\begin{array}{l}411 \\
399 \\
474 \\
\end{array}$ & \begin{tabular}{|l}
405 \\
391 \\
468 \\
\end{tabular} & $\begin{array}{l}450 \\
436 \\
413 \\
513\end{array}$. & $\begin{array}{l}437 \\
423 \\
499 \\
\end{array}$ & $\begin{array}{l}103 \\
390 \\
466 \\
\end{array}$ & $\begin{array}{l}414 \\
4010 \\
416 \\
\end{array}$ & $\begin{array}{l}411 \\
399 \\
474 \\
\end{array}$ & $\begin{array}{l}405 \\
391 \\
468 \\
\end{array}$ & $\begin{array}{l}466 \\
452 \\
529 \\
\end{array}$ & $\begin{array}{l}407 \\
393 \\
469 \\
\end{array}$ & 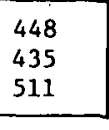 & $\begin{array}{l}414 \\
401 \\
476 \\
\end{array}$ & $\begin{array}{l}530 \\
598 \\
593 \\
593\end{array}$ & $\begin{array}{l}405 \\
391 \\
468 \\
\end{array}$ & $\begin{array}{l}406 \\
392 \\
469 \\
\end{array}$ & $\begin{array}{l}4 \begin{array}{l}406 \\
392 \\
468\end{array} \\
\end{array}$ & 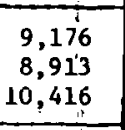 \\
\hline
\end{tabular}

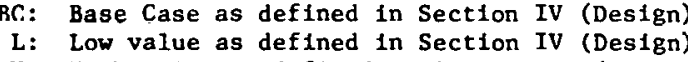

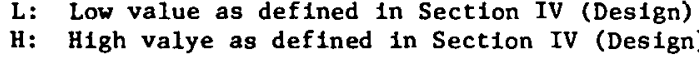




\section{THIS PAGE}

\section{WAS INTENTIONALLY \\ LEFT BLANK}


Therefore, as an example, the "low" cost for cultivation corresponds to the low level program of cultivation described above and the difference in cultivation cost between the low case and the base case reflects differences in the frequency of cultivation.

In the table:

- The high cultivation program assumes cultivation over 3 years, rather than 2 years as in the base case, and also assumes more frequent cultivations during the first 2 years;

- The high irrigation program includes supplementary irrigation over the base case program to compensate for water deficits during 25 days of drought;

- The high fertilization program assumes a 50 percent tecovery factor and therefore twice as much fertilizer must bet added as is removed with the harvested biomass; and

- The high level harvesting program assumes a productivity of 10 DTE per acre-year, the base case 8 DTE per acre-year, and the low case 5 DTE per acre-year.

The total operating costs for SRP-PSBF will be about 9 million dollars during its 24 year lifetime. Costs could be as much as 15 percent higher than this or they could be slightly lower. Average annual operating expenses will be about 0.5 million dollars after all modules have been installed.

Operating costs are summarized by item in Table XXIV. More than half the costs are personnel related. About half of these are associated with contractor management, supervision and reporting. They would be eliminated in a commerclal operation. Only the field personnel and small management staff would be rcquired an a commercial farm. Irrigation and fertilization are responsible for 14 and 


\section{TABLE XXIV}

SUMMARY OF THE PROJECTED OPERATING COSTS FOR THE

PILOT SILVICULTURAL BIOMASS FARM

(1978 DOLLARS)

\begin{tabular}{|c|c|c|c|c|}
\hline \multirow{3}{*}{ ITEM } & \multicolumn{4}{|c|}{ TOTAL OPERATING COSTS } \\
\hline & \multicolumn{2}{|c|}{ BASE CASE } & LOW & HIGH \\
\hline & $10^{3} \$$ & $\%$ & $10^{3} s$ & $10^{3} s$ \\
\hline $\begin{array}{l}\text { Cultivation } \\
\text { Irrigation } \\
\text { Fertilization } \\
\text { Harvesting } \\
\text { Replanting } \\
\text { Maintenance \& Repair } \\
\text { Personnel } \\
\text { Utilities \& Services } \\
\text { Equipment Replacement }\end{array}$ & $\begin{array}{r}455 \\
1,288 \\
918 \\
500 \\
66 \\
577 \\
4,872 \\
282 \\
418\end{array}$ & $\begin{array}{r}5.0 \\
14.0 \\
10.0 \\
3.3 \\
0.7 \\
6.3 \\
53.0 \\
3.1 \\
4.6\end{array}$ & $\begin{array}{r}305 \\
1,288 \\
918 \\
187 \\
66 \\
577 \\
4,872 \\
282 \\
8,913\end{array}$ & $\begin{array}{r}637 \\
1,349 \\
1,836 \\
379 \\
66 \\
577 \\
4,872 \\
282 \\
418\end{array}$ \\
\hline TOTẠ̇ & $9,1 ? 6$ & 100.0 & 8,913 & 10,416 \\
\hline
\end{tabular}


10 percent of the total operation cost, respectively. All other cost components are less than 6 percent and collectively account for 23 percent of the total.

The impact of variations in intensity of management are apparent from Table XXIV.

- A high intensity cultivation program will increase the total base case operating costs by about 2 percent.

- A high intensity irrigation program will increase the total base costs by about 1 percent.

- A high intensity fertilization program will increase the total base case costs by aluut 10 porcent.

- A high level of productivity (10 DTE per acre-year versus 8 DTE per acre-year) will increase the total base case costs by about one percent but the cost per dry ton will be less.

Summary Yearly Budgets

The annual installation and operation budgets for the SRP-PSBF are summarized in Table XXV. The low and high estimates are the sums of the low and high estimates for both the installation (Tables XX and XXI) and the operation (Table XXIII) budgets.

The total estimated cost of the SRP-PSBF is about 11 million dollars of which 1.7 milition dollars or 16 percent are Installation costs. About 9.3 million dollars or 84 percent are operation expenses.

Cost of Biomass and Energy Efficiency

The cost of producing biomass on the SRP-PSBF was estimated to be about $\$ 76$ per DTE or about $\$ 4.45$ per million Btu for the base case (8 DTE per acre-year). Corresponding costs for the low yield (5 DTE 
TABLE XXV

SUMMARY YEARLY TOTAL BUDGET FOR THE LIFETIME OF THE PILOT SILVICULTURAL BIOMASS FARM

(1978 Dollars)

\begin{tabular}{|c|c|c|c|c|c|}
\hline \multirow{3}{*}{$\begin{array}{l}\text { FISCAL } \\
\text { YEAR }\end{array}$} & \multicolumn{5}{|c|}{$10^{3} \$$} \\
\hline & \multicolumn{3}{|c|}{ BASE CASE } & \multirow{2}{*}{$\begin{array}{l}\text { LOW } \\
\text { TOTAL }\end{array}$} & \multirow{2}{*}{$\begin{array}{l}\text { HIGH } \\
\text { TOTAI }\end{array}$} \\
\hline & INSTALLATION & OPERATION & TOTAL ' & & \\
\hline 1980 & 567 & 216 & 783 & 753 & 835 \\
\hline 1981 & 152 & 246 & 398. & 378 & 423 \\
\hline 1982 & 319 & 264 & 583 & 552 & 643 \\
\hline ינ: 1983 & 160 & 279 & 439 & 416 & 481 \\
\hline 1984 & 336 & 294 & 630 & 592 & 715 \\
\hline 1985 & 175. & 314 & 489 & 452 & 565 \\
\hline $1986^{5 C}$ & 24 & 331 & 355 & 349 & 413 \\
\hline $1987^{\circ 10}$ & -- & 414 & 414 & 401 & 476 \\
\hline 1988 & -- & 411 & 411 & 399 & 474 \\
\hline 1989 & -- & 405 & 405 & 391 & 468 \\
\hline 1990 & -- & 450 & 450 & 436 & 513 \\
\hline 1991 & -- & 437 & 437 & 423 & 499 \\
\hline 1992 & -- & 403 & 403 & 390 & 466 \\
\hline 1993 & -- & 414 & 414 & 401 & 476 \\
\hline 1994 & -- & 411 & 411 & 399 & 474 \\
\hline 1995 & -- & 405 & 105 & 391 & 468 \\
\hline 1990 & -- & 466 & 466 & 452 & 529 \\
\hline 1997 & -- & 407 & 407 & 393 & 469 \\
\hline 1998 & -- & 448 & 448 & 435 & 511 \\
\hline 1999 & -- & 414 & 4.1 .4 & 401 & 476 \\
\hline 2.000 & -- & 530 & 530 & 518 & 593 \\
\hline 2001 & -- & 405 & 405 & 391 & 468 \\
\hline 2002 & -- & 406 & 406 & 392 & 469 \\
\hline 2003 & $-\cdots$ & 406 & 406 & 392 & 468 \\
\hline TOTAL & 1,733 & 9,176 & 10,909 & 10,497 & 12,372 \\
\hline
\end{tabular}


per acre-year) and high yield cases (10 DTE per acre-year) are $\$ 117$ per DTE or about $\$ 6.90$ per million Btu and $\$ 69$ per DTE or about $\$ 4.00$ per million Btu, respectively.

These biomass costs, however, are not representative of those expected for commercial operations because:

- Certain cost components such as project management are proportionally greater than for a commercial farm because of the relatively small size of the PSBF;

- Certain costs such as land fees probably will not be incurred at the SRP; and

- The above cost estimates assume eyual diotributinn nf total project costs over 129 equal (annual) harvest periods and Financial considerations such as depreciation, taxes and interest are not included.

Excluding costs directly related to the PSBF contractor such as travel, supervision and reporting could reduce the cost reported here by about $\$ 1.00$ per million Btu in the base case.

The Net Energy Efficiency* (NEE) of the system described here is about 90 percent. The energy used in growing, harvesting and hauling. the biomass includes fuel and fertilizer compounds. About 60 percent of the tulal energy consumed is fuel for the irrigation system and 25 percent is fertilizer.

*Ratio of the net energy yield to the gross (total) energy yield. 
THIS PAGE

\section{WAS INTENTIONALLY LEFT BLANK}




\section{APPENDIX}

TECHNICAL AND COST DATA. BASE USED FOR THE DESIGN OF THE PILOT SILVICULTURAL BIOMASS FARM

Contractors specializing in custom work of the type required to install and operate the Pilot Silvicultural Biomass Farm were contacted. The purpose of these contacts was (1) to obtain a design and implementation plan based on performance data, (2) to obtain cost estimates for the installation and operation of the PSBF, and (3) to identify areas of uncertainty concerning the operations and associated costs at the PEBF.

Many of the costs of installation and operation of the MSBF may be site sensitive. For each field operation, a base case cost was developed which represents the best available information. High and low cost estimates which represent possible extremes were also developed for the most sensitive operations.

Other areas of uncertainty are related to crop managenent activities such as weed control and to the actual productivity of the PSBF. Both of these will have an impact on the cost of operation. Here again, a base case was defined and high and low sases were proposed to establish a probable range of expected costs?

Contacts are identified and data gathered from them are discussed below under the following headings:

1. Surveying

2. Land Clearing

3. Land Preparation 
4. Irrigation System

5. Irrigation Wells

6. Planting

7. Research, Storage and Services

8. Cultivation

9. Fertilization

10. Irrigation

11. Harvesting

12. Maintenance and Repair

13. Personne 1

14. Equipment Replaçement

1. Surveying

Contact: Mr. Henry. McNab

U.S. Forest Service

$\therefore$ Savannah River. Plant

Aiken; SC 29801

(803) $725-6211$ (Ext. 2441)

Operations: Surveying of the two selected sites

Surveying of the six modules, roads

and research areas at each site

Contractor: Mr. Ronald o. Jernigan

Contract and Services Division

Savannah River Plant

Aiken, SC 29801

(803) 725-6211 (Ext. 2685)

Cost: The surveying will be performed at a negligible cost.

2. Land Clearing

Contacts: I. Mr. Henry McNab

U.S. Forest Service

Savannah River Plant

Aiken, SC 29801

(803) 725-6211 (Ext. 2441)

9.4 
II. Mr. Guy Sabin

Extension Forest Service

Clemson University

clemson, SC 29631

(803) $656-2478$

III. Mr. Thomas Mixon

Mixon Construction Co.

1303 Edisto Drive

Beech Island, SC 29842

(803) 593-5186

IV. Mr. William P. (Buddy) Bryan, III

Tifton Contractors, Inc.

P.0. Box 191

Tifton, GA 31794

(912) $382-3762$

Operations:

- Timber Sale - preferred method:

- involves marking the timber, estimating a fair market value, advertising the sale and selecting a contractor. All operations performed by the U.S. Forest Service. Contracts will be established by the Contract and services Division, Savannah River Plant; Mr. Ronald D. Jernigan (803-725-6211, Ext. 2685).

- highest cash return to the Federal Government.

- time required: up to 24 months per tract 1.cleared; can be reduced to 15 months.

- cost to the pro.ject: salaries of USFS personnel organizing the sale.

- Salvage Sale - involves estimating the price to be paid by the contractor on a dullarg per, truck-load bas is (U.S. Forest Service), and negotiating salvage contracts (Contracts and Services Division).

- lesser return to the Treasury.

- time required: about 6 months.

- salvage contracts with various operators exist currently and could be extended to include clearing of the PSBF wodules.

- cost to the project: - salaries of USFS personnel organizing the sale. 
- Clearing with No Timber Recovery -

- clearing and disposal of the timber by a local operator.

- no return to the Government.

- total period: 4 to 6 weeks for 200-acre tracts (References III and IV).

- costs quoted:

- \$100/acre: reference III.

- \$300/acre: reference IV.

- \$65 to \$120/acre: reference II. Quotations from individual contractors in South-Carolina. These data have not yet been published.

- costing base:

- Base case: \$80/acre.

- Low value: \$65/acre.

- High value: $\$ 150 /$ acre.

3. Land Preparation

Contacts: I. Mr. Thomas Mixon

Mixon Construction Co.

1303 Edisto Drive

Beech Island, SC 29842

(803) 593-5186

II. Mr. William P. (Buddy) Bryan, III

Tifton Contractors, Inc.

P.O. Box 191

Tifton, GA 31794

(912) $382-3762$

III. Mr. Guy Sabin

Extension Forest Service

Clemson University

Clemson, SC 29631

(803) 656-2478

IV. Mr. Henry Leach

Leach Rental Center

Warrenton, VA 22186

(703) 347-2899

V. R. L. Rider \& Company

30 Marshall Street

Warrenton, VA 22186

(703) 347-1611 
Operations: Land preparation: root-raking, stump/slash disposal by burning and spreading of the ash followed by heavy disking which will prepare the land. Drainage ditches: renovation of existing ditches and/or installation of new ditches 8 feet deep. Work roads: crowning of dirt roads and ditching on sides of $25^{\prime}$ wide work roads.

Land Preparation:

- Cost quoted: $\$ 400$ to $\$ 600 / a c r e:$ reference I. $\$ 1,000 / a c r e:$ reference II.

\$175/acre: reference III. Based on average state-wide prices for disking, root-raking, drum chopping and shearing. $\$ 80$ to $\$ 135 / a c r e:$ reference III. Values quoted by individual contractors in South Carolina.

- Costing base: Base case: \$200/acre. l'h1s cost was determined using hourly rates for machinery and labor supplied by reference II. Time required for each operation supplied by reference III. Low case: $\$ 145 /$ acre. High case: $\$ 300 /$ acre.

- Duration of work: 2 months for one module at each site including drainage ditches and work roads.

Drainage ditches:

- Costs quoted: $\$ 0.50 / f t$ : reference I.

$\$ 2.50 / f t:$ reference II.

$\$ 3.00 / f t:$ reference IV.

- Costing base: Base case: $\$ 2.50 / f t$.

Low case: $\$ 1.50 / \mathrm{ft}$.

High case: $\$ 3.50 / \mathrm{ft}$. This cost includes provisions for brush and tree removal and the installation of culverts.

Work roads:
- Costs quoted: $\$ 1.50 / f t:$ reference II. Admittedly a
"wild guess."
$\$ 0.25 / f t:$ reference V.
- Costing base: Base case: $\$ 0.50 / \mathrm{ft}$. 
4. Irrigation System

Contact: $\quad$ I. Reed Irrigation Systems

SE Regional office

P.0. Box 1412

908 Railroad Avenue

Winter Park, FL 32789

$\mathrm{Mr}$. Tom Kimme 1

(305) 647-6153

II. Rain Bird Corporation

7045 North Grand Avenue

Glendora, CA 91740

Mr. Julian Pitch ford

(213) 963-9311

Design: The design proposed by Reed Irrigation Systems has the following characteristics (see Figure 7 and 8 in the text and the attached drawings describing the layout of the proposed irrigation system):

- Two annual modules are irrigated with water from one well.

- The system is designed for the irrigation of one-half module at a time. A complete irrigation cycle therefore will include four successive periods of irrigation.

- Peak evapotranspiration rates were determined for 6year-old stands occupying 100 percent of the land, and for 1-year-old stands occupying about 10 percent of the land uoing climatic data for Augusta, Georgia and Columbia, South Carolina. It was estimated that the daily peak water requirements of one-half module at the Jackson Site could be met by a well delivering about 900 gallons per minute (GPM) over an 8-hour irrigation period. The corresponding peak water requirement at the Route 278 site is about 450 GPM. One-year-old trees would require only 0.8 hour of irrigation daily at either site to satisfy their water requirements. It should be noted that:

- The irrigation requirements estimated above assume no rainfall (peak demand during drought period).

- At pumping capacities of 400 and 500 GPM for the Jackson and Route 278 sites a total of 29 hours would be required to meet peak daily water 
requirements of two modules in their fifth and sixth year growth. This is partially compensated for by the fact that the well pumps are overdesigned by about 10 percent.

- The irrigation system includes 6 and 8 inch diameter mains buried 3 feet in the ground, and 4 inch and smaller submains buried 18 inches in the ground. Each main and submain line includes flow control valves and each submain line ends with a flushout valve. Risers connected every 8 feet along the submains feed the plastic irrigation lines. The latter may be buried a few inches underground for protection from damage by machinery or they can be laid above ground. Ten psi tubing with drip holes every 24 inches is recommended.

- The irrigation system at each site includes three sand filters to eliminate grit and dirt from the irrigarion wacer and three five-thousand gallon tanks with injection pumps to store and feed liquid fertilizer to the irrigation system.

- The irrigation system will be installed in two phases: (1) the mains and submains will be installed after the land is prepared, and (2) the drip tubing will be laid or buried at the time of planting. This can be done by uncoiling the tubing from two reels of tubing mounted 8 feet apart on a wagon pulled by a tractor. Tools.will be mounted on the wagon to open a trench and to cover the tubing if it is installed underground. No commercially available machinery exists to perform this operation. A row planter can be attached to a wagon to perform both the installation of the tubing and the planting in one step.

- The drip tubing should be replaced after each harvest every six years.

- Diesel pumps are recommended by the designer (reference I) for the irrigation system to assure the best possible flow control.

Cost/Installation: The cost of the irrigation system was estimated for each module using cost data and design 
drawings supplied by Reed Irrigation. The average cost (materials and labor) is:

Base case: $\$ 530 /$ acre

Low case: $\$ 500 /$ acre. This low cost can probably be achieved if experienced workers are used to lay the drip tubing.

Drip Tubing Replacement: The base cost for drip tubing is about $\$ 30 / 1,000$ feet. This price was confirmed by another supplier (Reference II). The cost of replacement (labor and materials) of the tubing is:

Base case: $\$ 230 /$ acre

Low case: $\$ 200 /$ acre

Duration of Installation: The time required for installation of the irrigation system is four months. This includes ordering and delivery of materials and installation of the mains and submains. The drip tubing is installed at the same time that the seedlings are planted.

\section{Irrigation Wells and Pumps}

We11s:

Contacts: I. Heater Well Company Columbia, SC 29200 (803) $754-2862$

II. McCall Brothers, Inc. Charlotte, NC 28200 (704) 399-1506

\section{General Description}

- Expected Physical Characteristics:

Depth: 150 to 250 feet to aquifer 200 feet of aquifer 350 to 450 feet total depth

Soil: Medium to coarse sand/clay 20-25 GPM per foot drawdown 
- General Specifications:

Minimum inside casing diameter: 10 inches

Minimum surface casing diameter: 20 inches

Gravel packed over 200 feet

Screen over 200 feet

$$
\begin{array}{r}
1000 \text { GPM (Jackson site) } \\
500 \text { GPM (Route } 278 \text { site) }
\end{array}
$$

Cost Estimates: Cost includes test well, production well (1abor and materials) and installation (but not supply) of the pump :

\section{Costs quoted:}

$\begin{array}{lll}1000 \text { GPM We11: } & \$ 69,000: & \text { Reference I } \\ & \$ 63,000: & \text { Reference II } \\ 500 \text { GPM We11: } & \$ 55,000: & \text { Reference I } \\ & \$ 45,000: & \text { Reference II }\end{array}$

\section{Costing Base:}

$\begin{array}{rccc}1000 \mathrm{GPM} & \frac{\text { Low }}{1,000} & \frac{\text { Base Case }}{\$ 65,000} & \$ \frac{\text { High }}{9,000} \\ 500 \mathrm{GPM} & \$ 45,000 & \$ 50,000 & \$ 59,000\end{array}$

The high case includes provisions for drilling several test wells if necessary.

Pumps and Motors:

Contacts: III. Goulds Pumps, Inc.

Seneca Falls, NY 13148

IV. Detroit Dièsels

Detroit, MI 48200

\section{General Description:}

- Pump:

Surface line shaft turbine pump

$1000 \mathrm{GPM}$ or $500 \mathrm{GPM}$ at $10-15$ psi surface level pressure

Total head: 375 feet

Designed for 1750 RPM with 1:1 right angle drive

Maximum diameter: 12 inches for $1000 \mathrm{GPM}$

Water or oil lubricated

$$
10 \text { inches for } 500 \mathrm{GPM}
$$


- Diesel Motor:

500 GPM pump: $\quad 64 \mathrm{HP}$ at $1800 \mathrm{RPM}$

1000 GPM pump: $117 \mathrm{HP}$ at $1800 \mathrm{RPM}$

Fuel consumption: $0.42 \mathrm{lb}$ fuel/BHP-hr or

7 gallons/hour for $1000 \mathrm{GPM}$

4 gallons/hour for $500 \mathrm{GPM}$

Cost Estimates:

Base case: $1000 \mathrm{GPM}: \$ 25,000$

500 GPM: $\$ 20,000$

Total System

- Costing Base:

\begin{tabular}{|c|c|c|c|}
\hline 1000 & $\$ 8 \frac{\text { Low }}{6,000}$ & $\frac{\text { Base Case }}{\$ 90.000}$ & $\$ 10 \frac{\mathrm{High}}{4.000}$ \\
\hline $500 \mathrm{GPM}$ & $\$ 65,000$ & $\$ 70,000$ & $\$ 79,000$ \\
\hline
\end{tabular}

- Duration of Installation: 6 months including order, delivery of materials and installation of the wells and pumps.

6. Planting

Seedlings:

Contacts: Mr. Marvin T. Gaffney

South Carolina State Commission nf Forcatiy

P.0. R०X 21707

Columbia, SC 29221

(803) 758-2261

Seventeen potential suppliers of seedlings were contacted. The South Carolina State Commission of Forestry (SCSCF) was the only supplier who could guarantee the delivery of all the seedlings needed by the project.

Object: Supply about 230,000 one-year-old bare-root seedlings of sycamore (Platanus occidentalis) and European alder (Alnus glutinosa) yearly starting in early 1981 for six years; and supply about 114,000 one-year-old bare-root seedlings of slash pine (Pinus elliottii Engelm. var. elliottii) in early 1981 and 1982. This latter order will be repeated every six years. 
The SCSCF nursery will grow, lift, pack, and cool-store the seedlings for pickup by the PSBF just before planting. The volume of a package of 1,000 seedlings (with mulch) is about 5 cubic feet and weighs less than 100 pounds. Delivery from the nursery to the PSBF, therefore, is possible with a pickup truck. It is recommended that the seedlings be picked up just before planting to avoid storage under nonoptimal conditions. This will insure better survival. Losses by damage through handing, transportation and planting are generally less than 1 percent.

\section{Cost:}

The price per thousand seedlings, f.o.b. nursery, is:

$$
\begin{array}{ll}
\text { Sycamore: } & \$ 30.00 \\
\text { Europoan Alder: } & \$ 30.00 \\
\text { Slash Pine: }: & \$ 10.00
\end{array}
$$

Scheduling: Seedlings must be ordered at the latest by September 1, year $\mathrm{N}$ minus 2 for planting in February of year N. September 1, 1979, is thus the first critical date if planting of the first modules is to be initiated on February 1, 1981.

The nursery should be notified about two weeks before pickup of the seedlings by SRP operations.

Planting: Planting operations at each site will require about one month per module.

Contacts: I. Mr. Henry C. McNab

U.S. Forest Service

Savannah River Plant

Aiken, SC 29801

(803) 725-6211 (Ext. 2441)

II. Mr. J. Zavitkovski

USDA Forest Service

Rhinelander, WI 54501

(715) $3.62-7474$

III. Mr. John Nugent

International Paper Company

Natchez, MS 39120

(601) 442-7421 (Ext. 297) 


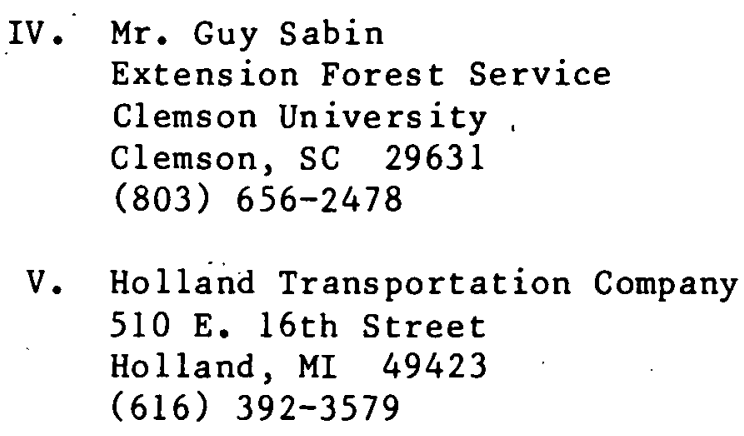

Operation: Planting of one-year-old bare-root seedlings 2 feet apart in rows 8 feet apart. The operation can be performed with a 2 row mechanical planter (Contacts II and $V$ ). Two men are required for the actual planting. A third man will be assigned to the crew to deliver seedlings and perform other maintenance and support tasks. It is recommended (see Appendix Section 4) that planting and installation of the drip irrigation tubing be performed simultaneously. As described above, this will require modification of existing equipment and, specifically, the connection of a mechanical planter (Contact $V$ ) to the wagon installing the irrigation tubing.

Data supplied by contacts I to IV suggest that about 7,000 seedlings can be planted in a day by a three-man crew. Planting a module at each site would thus require about 65 working days. Taking holidays and bad weather into account, three planters will be required to plant one module at each site within the planting window, i.e., the month of February. It is suggested that three planters be purchased and outfitted with irrigation tubing installation equipment.

\section{Costs:}

- Costs quoted:

$\$ 18 /$ acre to $\$ 43 /$ acre: Contact IV, data from individual contractors

\$30/acre: statewide average, Contact IV

- Costing base: $\$ 55 / a c r e$. This cost was derived from the planting rate quoted above ( 7,000 seedlings per day) and current labor rates for Georgia. The higher value adopted for the estimates reflects the fact that standard practice ( $\$ 30$ per acre) refers to the planting 
of about 600 trees per acre which enables the planters to move faster. The estimate includes a 0.9 labor efficiency factor.

7. Research, Storage, and Services

Contacts: Various suppliers of equipment required at the site. Operations: Delivery and installation of research and storage buildings, and equipment at both. sites.

Buildings:

Trailer homes converted to office and research uses: Jackson site: $\quad 1,500 \mathrm{ft}^{2}$ Route 278 site: $800 \mathrm{ft}^{2}$

Cost: $\$ 20 / \mathrm{ft}^{2}$ installed with supporting masonry

Storage buildings: prefabricated metal structures Jackson site: $3,000 \mathrm{ft}^{2}$

Route 278. site: 2,000 $\mathrm{ft}^{2}$.

Cost: $\$ 9.50 / \mathrm{ft}^{2}$ installed including supporting masonry and concrete slabs.

\section{Equipment:}

Trucks: pickup trucks, 1 ton, 4-wheel drive, gasoline powered

Three units for the PSBF

Cost: $\$ 8,000 /$ unit

Tractor: John Deere $40 \mathrm{HP}$, diesel, or equivalent, with accessories (bushhog, blade, rake, etc.)

Cost: $\$ 20,000$ with accessories

Dump Wagon: 8 ton capacity, tractur pulled

Two units for harvesting operations

Cost: $\$ 7,500 /$ unit

Research and office: standard office equipment; small

laboratory equipment (balance, oven, chemical analysis glassware and chemical,...) and small field equipment

for research areas (lawnmower, rototiller, etc.)

Estimated cost of complete set of equipment: $\$ 30,000 / \mathrm{set}$

Services: telephone, septic field, gasoline and diesel ruel tanks, power lines 
Éstimated cost of installation of services: $\$ 20,000$ per site

\section{Cultivation}

Cultivation Schedule

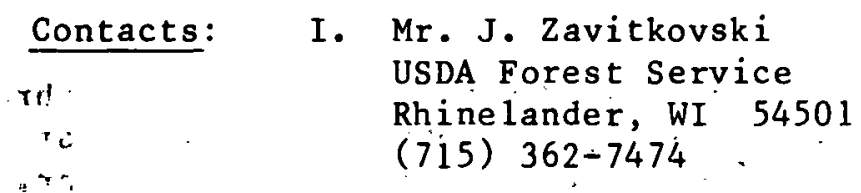

II. Mr. M. Morain

Packaging Corporation

Filer City, MI 49634

(616) 723-9951

III. Mr. R. Heeren

Union Camp Corporation

Franklin, VA 23851

(804) 569-4321

IV. Mr. John Nugent

International Paper Company

Natchez, MS 39120

(601) 442-7421 (Ext. 297)

Operation: Control of weed growth between the rows of seedlings. The level of cultivation required is strongly influenced by local factors such as soil moisture, climate, previous land 1150 , etc. At present weed control io generally achieved by mechanieal cultivation, i.e., disking. Weed control by chemical means is being investigated but not enough data are available at present to propose this method for the PSBF. Weed control by disking is thus recommended for the PSBF.

Schedule: The cultivation programs presently practiced by the above contacts ( $I$ to IV) include cultivation every two to four weeks during the first growing season after planting or harvesting, every'four to seven weeks during the second growing season and sometimes once or twice during the third growing season.

The following cultivation program was adopted for the design of the PSBE: 
$\underline{\text { Year }}$

$\begin{array}{cccc} & \text { Low } & \text { Base Case } & \text { High } \\ 1 & 5 & 7 & 10 \\ 3 & 3 & 5 & 6 \\ 3 & 0 & 0 & 1\end{array}$

The base case corresponds to cultivation about every three weeks during the April-early September period the first year and about every four to five weeks the second year.

Cost of Cultivation:

Contacts: I. Mr. John Nugent

International Paper Company

Natchez, MS 39120

(601) 442-7421 (Ext. 297)

II. Mr. M. Morain

Packaging Corporation

Filer City, MI 49634

(616) 723-9951

III. Dr. D. Smith

Department of Agricultural Economics and

Rural Sociology

Clemson University

Clemson, SC 29631

(803) $656-3223$

IV. Mr. Thomas Mixon

Mixon Construction Company

1303 Edisto'Drive

Beech Is land, SC 29842

(8ח3) 593-5186

II. Mr. William P. (Buddy) Bryan, III

Tifton Contractors, Inc.

P.0. Box 191

Tifton, GA 31794

(912) $382-3762$

Costs quoted: $\$ 4 / a c r e$, Contact II

$\$ 5-6 / a c r e$, Contact III, average cost quoted by

farmers for a state survey

$\$ 50 /$ acre, Contact IV

$\$ 100 /$ acre, Contact V 


\section{Costing base:}

Base case: $\$ 10 / a c r e$. This cost was derived from performance data for the machinery involved (Contacts I and II) and the hourly cost for machinery (Contacts III and IV). It assumes that the work will be performed by subcontractors. Using the same data, the cost would be $\$ 6 /$ acre if the machinery was owned by the PSBF. The difference in cultivation cost does not justify the investment in machinery by the PSBF. It was thus assumed that all cultivation operations would be subcontracted.

Low case: $\quad \$ 9 /$ acre

High case: $\$ 12 /$ acre

\section{Fertilization}

\section{Fertilizer}

Contacts: I. Dr. I. Wofford/Mr. Walt Foster

Kaiser Agricultural Chemical Company

Savannah, GA 31400

(Wof ford) (912) 964-4311

(Foster) (912) 791-4080

II. W.. R. Grace Company

Memphis, TN 38100

Operations: Supply of liquid fertilizer for application through the irrigation systeme.

Description and Cost:

\section{Product}

Urea - Ammonium Nitrale Solution

$(30 \% \mathrm{~N})$

Urea - Superphosphate solution

$\left(10 \% \mathrm{~N}-34 \% \mathrm{P}_{2} \mathrm{O}_{5}\right)$

Potassium oxide solution

$\left(15 \% \mathrm{~K}_{2} \mathrm{O}\right)$

Micronutrients (Chelates)

Copper $(7.5 \%, \mathrm{Cu})$

Magnesium (2.5\% Mg)

Manganese ( $5 \% \mathrm{Mn})$

Zinc $(9 \% \mathrm{Zn})$
Cost, \$/ton, f.o.b. Aiken, SC

90

155

50

1,700

1,300

1,300

1,500 
The N-P-K fertilizers are supplied in 20 ton tanks (about 5,000 gallons) and the micronutrients are supplied in 50 pound pails.

\section{Fertilization Program}

Contacts and References:

I. R. E. Inman, D. J. Salo and B. J. McGurk, Silvicultural Biomass Farms, Volume IV, The MITRE Corporation, May 1977 .

II. D. J. Salo, R. E. Inman, B. J. McGurk and J. Verhoeff, Silvicultural Biomass Farms, Volume II.I, The MITRE Corporation, May 1970.

III. Mr. J. Nugent

International Paper Company

Natchos, MT 39120

(601) 442-7421 (Ext. 297)

IV. Mr. J. Zavitkovsky

USDA Forest Service

Rhinelander, WI 54501

(715) $362-7474$

V. U.S. Environmental Protection Agency, Land

Treatment of Municipal Wastewater, Technology

Transfer, EPA 625/1-77-008, October 1977 .

VI. Mr. Julian Pitchford

Rain Bird Corporation

7045 North Grand Avenue

Glendora, CA 91740

Fertilizer Requirements. Annual fertilization requirements were determined by two independent methods. In the first method, data expressing the content of nutrients ( $N, P$ and $K$ ) in young hardwoods (Contact I) were used to determine the amount of nutrients needed per acre-year at various stages of growth of the plants. The second method relies on current agricultural practice on pasture land in Georgia (Contact II). As shown in Table XII of the text, these two estimates agree fairly well as far as the estimates of nitrogen requirements are concerned. The propused rates nf application of nitrogen are of the same order as those adopted by other groups (Contacts III and IV) and those recommended by the U.S. Environmental Protection Agency. 
for land treatment with wastewaters. It should however be noted that there is a large uncertainty concerning the actual nutrient requirements of short rotation energy farms. A high case which would require twice the amounts of nutrients estimated above was therefore considered as an upper limit.

Actual amounts of formulated fertilizers were determined assuming a 60 percent recovery factor. The phosphorus requirements were first determined as this nutrient $\left(\mathrm{P}_{2} \mathrm{O}_{5}\right)$ is supplied in a mixture with urea. The requirements of nitrogen fertilizer (urea-ammonium nitrate) were then determined to bring the total amount of nitrogen to the level suggested.

Yearly Fertilization Program: The nutrients will be applied at regular intervals during the growing season to avoid build-ups or losses and to keep plant uptake at its optimum (Contacts III and IV). The nutrients will be applied through the irrigation system either during a normal irrigation cycle or during supplemental

irrigations. Nutrients will be applied over a period of 6 hours of irrigation which will be followed by a 2 hour period of flushing. This practice is successfully used on orchards (Contact VI) and avoids clogging of the drip holes by crystalized nutrients and build-up of algae within the irrigation tubes.

Soils at the Jackson site (see Appendix) will retain nutrients and this site, therefore, should he. fertilized four times during each growing season. These applications may not correspond to the irrigation schedule proposed for the site and supplementary water will be needed for fertilizer application. It is estimated that about 400 hours of irrigation will be required to apply fertilizer annually at the Jackson site, i.e.:

6 modules/site $x 2$ half modules/module $x 8$ hours/half module per application $\times 4$ applications/year $\simeq 400$ hours/year

The pumping requirements for fertilization at the Jackson site were added to the operating cost for normal irrigation at the site.

Soil at the Route 278 site is sandy. The normal irrigation program involves water application about 
every two days. Fertilizer application can therefore be included in this schedule without supplementary application. It is suggested (Contact VI) that fertilizer be applied frequently, such as every two weeks, because the soils are subject to leaching.

\title{
10. Irrigation
}

Contacts and References:

\author{
I. R. E. Inman, D. J. Salo and B. J. McGurk, \\ Silvicultural Biomass Farms, Volume IV, The \\ MITRE Corporation, May 1977.
}
II. Mr. Julian Pitchford
Rain Bird Corporation
7045 North Grand Avenue
Glendora, CA 91740

\section{Irrigation Program:}

- Jackson Site. It has been estimated that onc acre-foot of irrigation water per year will be required at this site (Reference I). For the design capacity of 1,000 GPM, pumping time per acre-year at full capacity will be about 3,000 hours. This corresponds to irrigation of each module about once a week and will be adopted as the base case for this site.

A high case is also considered. It assumes that full irrigation of the site will be needed during 15 days of drought as a supplement to. the normal irrigation requirement of one acre-foot per year. The irrigation system is designed to supply all the water needs of a six-yeai onc-half module (about 50 acres) during an eight hour period. Taking into account the differences in ages among modules, the anticipated additional water need during drought years will required another 400 hours of full-capacity pumping at the site.

The design cases for irrigation at the Jackson site are therefore:

Base case: 5.5 hours at full pumping capacity/acreyear

High case: 7.0 hours at full pumping capacity/acreyear 
- Route 278 Site. In view of the sandy nature of the site, two acre-feet of water will be applied regularly during the growing season. This irrigation program is comparable to that practiced in California on orchards (Contact. II) and will result in the irrigation of each module about every two days. Following the procedure described above, it is estimated that this program will require about 3,000 hours of pumping per acre-year at full capacity ( $500 \mathrm{GPM}$ ). Only this base case will be considered for the Route 278 site.

Irrigation Costs. Fuel costs were determined for the irrigation program using the manufacturers fuel consumptions for the irrigation systems ( 7 and 4 gallons diesel fuel/ hour at full capacity at the Jackson and Route 278 sites, respectively) and a diesel fuel cost of $\$ 0.52 / g a l l o n$ (Department of Agriculture, Agricultural Prices, Washington, D.C., June 30, 1978).

- Jackson site - Base case: $\$ 20.00 /$ acre-year High case: $\$ 25.00 /$ acre-year

- Route 278 site - Base case: $\$ 25.00 /$ acre-year

Operation and maintenance costs are included in the PSBF site personnel and maintenance costs.

\section{Harvesting}

Contact: I. Morhark

Mr. Leo Bronson

Also, demonstration of a whole tree and chipper in McLean, Virginia, in January 1978.

II. Rockwell Engineering Company

Blue Island, IL 60406

III. Fuller Manufacturing Company Centerville, IO 52544

Operation: Harvesting and chipping of six-year-old trees. Prototypes of harvester-chipper for silvicultural energy farm use are presently under development. 
Characteristics of the Harvesting Equipment: For lack of test data, the characteristics of present-day fixed whole-tree chippers were used for costing purposes:

- harvesting capacity: 20 green tons/hour

- fuel consumption: 15 gallons diesel fuel/hour

- field efficiency: 0.9 , including time required for the periodic exchange of blades (harvester and chipper)

- personnel: one heavy machinery driver-operator, one laborer for maintenance, blade exchange, fueling and other support tasks. Laborers will be hired for the harvesting season at $\$ 6.50 /$ hour and $\$ 4.50 /$ hour, respectively, plus 20 percent overhead. Work on weekends or holidays will be paid at a rate of 1.5 . Work will be performed during two eight-hour shifts per day.

Support Equipment: Two dump wagons will be required for wood chip collection during harvesting and transportation of the chips from the field to the storage area. While one wagon pulled by the harvester is being loaded, the other wagon filled with chips will be pulled by a tractor to the storage area. These operations will be performed by permanent PSBF personnel. The characteristics of these wagons are (from Contacts I and (II):

- capacity: 8 tons

- hydraulic lift for dumping

- cost: $\$ 7,500 /$ unit

Harvesting Schedule and Cost: Harvesting will be performed during the dormant season, i.e., mid-November to the end of February. Even in the case of high productivity, i.e., 10 DTE/acre-year, all harvesting operations can be performed during weekends ( 2 shifts per day). No overtime pay will be necessary. Using the fuel consumptions quoted above for the harvester, a consumption of 3.5 gallons/hour for the eractor, 3 cost of $\$ 0.52 / \mathrm{gal}$ for diesel fuel and the labor rates cited above, the cost of harvesting is estimated at: 
- Base case: fuel cost: $\$ 43 /$ acre

personne 1: $\quad \$ 63 /$ acre

total: $\$ 106 /$ acre

- High case: fuel cost: $\$ 54 /$ acre

personnel: $\$ 79 /$ acre

total:

$\$ 133 /$ acre

- Low case: fuel cost: $\$ 27 /$ acre

personne 1: $\quad \$ 39 /$ acre

total: $\quad \$ 66 /$ acre

Salaries of permanent PSBF personnel used during harvesting are not included in the above cost estimates.

\section{Maintenance \& Repair}

\section{Contacts: Equipment suppliers}

Operations: Annual maintenance and repair of equipment owned and used by the PSBF.

Costs: The following maintenance and repair ( $M \& R)$ costs were used in the estimates.

Equipment

Pickup Trurk

Tract or

Dump Wagon

Diesel motors and pumps

Harvester.

Planters

Buildings

Small equipment (chain saws, etc.)

Roads are reconditioned every six years after harvesting of a module. The cost is assumed to be the same as that for the original grading and ditching work (see Section 3 of this Appendix).

Services (phone, utilities, heating/cooling, gasoline for trucks, office supplies) are estimated at $\$ 1,000 /$ month for both sites.
M\&R Cost

\$/Unit-year

2,400

1,000

750

2,000

10,000

1,500

2,, 000

5,000 


\section{Personnel}

The permanent personnel required to manage, operate, analyze and report the results of PSBF operators include:

Contractor or Interim Contractor

1 senior scientist

$\frac{\text { S/ year }}{25,000}$

1 junior scientist

15,000

1 part-time secretary

$\frac{9,000}{49,000}$

Personnel at the PSBF

I supervisor

25,000

2 qualified machine operators

30,000

1 clerk

$\frac{8,000}{63,000}$

Total:

Overhead: $60 \%$

112,000

$\frac{68,000}{180,000}$

$\frac{68,000}{180,000}$

Temporary personnel: 60 mandays

(a) 10 hours/day, $\$ 4.50 /$ hour, $20 \%$ ove rhead

Total personnel

Trave1, reporting, miscellaneous

TOTAL

16,800

200,000

14. Equipment Replacement

Contacts: Equipment suppliers.

Lifetime of the Equipment:

Equipment

Pickup truck

Tractor

Dump wagon

Diesel motors and pump

Buildings.

Harvester.

Planter

\section{Lifetime-years}

10

10

10

$\because \quad 15$

30

Unknown

10

The irrigation tubing is replaced every six years after harvesting of a module. The cost of this operation was discussed in section 4 of this Appendix. 


\title{
United States
}

Department of Energy

Washington, DC 20545

U.S. Department of Energ DOE-360

\section{U.S.MAII}

Penalty for Private Use, $\$ 300$

\author{
THIRD CLASS MAIL
}

